
Buku Ajar

\title{
KAJIAN LINGKUNGAN DAN PERENCANAAN \\ PEMBANGUNAN
}

Oleh

Zul Azhar

\author{
Editor \\ Prof. Dr. Hasdi Aimon, M.Si \\ Desain Cover \\ Zadrian Ardi, S.Pd, M.Pd, Kons \\ Kata Sambutan \\ Dekan Fakultas Ekonomi UNP \\ Dr. Idris, M.Si
}

\section{FAKULTAS EKONOMI}

\section{UNIVERSITAS NEGERI PADANG \\ 2017}




\section{KATA PENGANTAR}

Penulis telah lama ingin menerbitkan Buku Ajar Kajian Lingkungan dan Perencanaan Pembangunan yang bisa dipakai oleh mahasiswa. Buku Kjian Lingkungan dan Perencanaan Pembangunan ini berpijak dari pengalaman penulis mengajarkan mata kuliah perencanaan Pembangunan dan Ekonomi Regional. Hal ini banyak ditemukan dilapangan bukti pisik dan nyata kasus-kasus pembangunan yang telah direncanakan baik pemerintah maupun pihak swasta yang memberikan resiko setelah pembangunan selesai.

Pada hal jika dirujuk kebelakang sebelum pembangunan dilaksanakan harus sudah ada izin dan sesuai dengan aturan bahkan sudah ada pula AMDAL. Kenapa terjadi juga kasus setelah pembangunan berjalan ?. Hal inilah yang menarik penulis untuk mengkaji peristiwa dan kejadian itu setelah diidentifikasi satu persatu kasus ternyata ada kelemahannya. Kelemahan yang penulis temukan diprediksi adalah perencana mengandalkan renca yang dibuat tanpa berpikir kedepan apa yang akan terjadi. Pada hal perencana sudah memprediksi kedepan, tetapi belum mengkaji lingkungan. Hal inilah penulis mengkaitkan antara Kajian Lingkungan dengan Pembangunan.

Untuk itu penulis tertarik menulis buku ajar Kajian Lingkungan dan Perencanaan Pembangunan ini sabagai pedoman dan bahan diskusi dalam perkuliahan sebagai mana motto Universitas Negeri Padang “ Alam Takambang Jadi Guru".

Akhir kata, semoga buku ajar ini akan berkembang menjadi buku yang bisa dipakai banyak orang dan terima kasih.

Padang 28 Pebruari 2018

Penulis,

dto

Zul Azhar 


\section{KAJIAN LINGKUNGAN DAN PENCANAAN PEMBANGUNAN}

\section{DAFTAR ISI}

Halaman

$\begin{array}{lll}\text { BAB I PENDAHULUAN } & 1\end{array}$

A. PENGERTIAN KAJIAN 1

B. PENGERTIAN LINGKUNGAN

C. KAJIAN LINGKUNGAN 3

D. PENGERTIAN WILAYAH

E. PENGERTIAN LOKASI 6

$\begin{array}{ll}\text { F. PENGERTIAN RUANG } & 7\end{array}$

$\begin{array}{lll}\text { BAB II KAJIAN LINGKUNGAN DAN PEMBANGUNAN } & 11\end{array}$

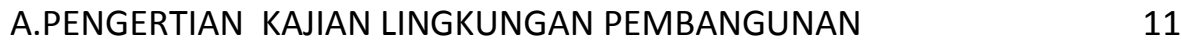

B. PENGERTIAN KAJIAN LINGKUNGAN HIDUP STRATEGIS 11

$\begin{array}{ll}\text { C. KEGUNAAN AMDAL } & 14\end{array}$

D. HUNGUNGAN KAJIAN LINGKUNGAN DENGAN PEMBANGUNAN 16

$\begin{array}{lll}\text { BAB III PERENCANAAN PEMBANGUNAN } & 18\end{array}$

$\begin{array}{ll}\text { A. PENGERTIAN PERENCANAAN } & 18\end{array}$

$\begin{array}{ll}\text { B. PERENCANAAN PEMBANGUNAN } & 21\end{array}$

$\begin{array}{ll}\text { C. PERKEMBANGAN PEENCANAAN } & 23\end{array}$

D. HUBUNGAN PERENCANAAN DENGAN RENCANA 26

E. CIRI-CIRI RENCANA YANG BAIK 30

F. BENTUK-BENTUK PERENCANAAN 34

G. UNSUR-UNSUR PERENCANAAN 38

H. HUBUNGAN RENCANA DAN PEMBANGUNAN 43

G. PERENCANAAN YANG BAIK $\quad 50$

BAB IV PERENCANAAN PEMBANGUNAN EKONOMI

A. PERLUNYA PERANCANAAN EKONOMI 52

B. MASALAH-MASALAH DALAM PERENCANAAN EKONOMI 52 
$\begin{array}{lll}\text { BAB V PERENCANAAN PRODUKSI } & 68\end{array}$

A. PENGERTIAN PRODUKSI 68

$\begin{array}{ll}\text { B. TEORI PRODUKSI } & 70\end{array}$

C. FAKTOR-FAKTOR PRODUKSI

$\begin{array}{ll}\text { D. TEORI ONGKOS } & 75\end{array}$

E. MODEL SENTRA PRODUKSI

$\begin{array}{lll}\text { BAB VI EKONOMI LINGKUNGAN } & 85\end{array}$

A. PENGERTIAN EKONOMI LINGKUNGAN 85

B. PENYEBAB MEROSOTNYA FUNGSI LINGKUNGAN 86

$\begin{array}{ll}\text { C. KEGAGALAN PERENCANAAN PEMERINTAH } & 90\end{array}$

D. NILAI EKONOMI TOTAL 94

E. PEMBANGUNAN EKONOMI DAN LINGKUNGAN 99

$\begin{array}{ll}\text { DAFTAR PUSTAKA } & 101\end{array}$ 


\section{KAJIAN LINGKUNGAN DAN PENCANAAN PEMBANGUNAN}

DAFTAR ISI

Halaman

$\begin{array}{ll}\text { BAB I PENDAHULUAN } & 1\end{array}$

$\begin{array}{ll}\text { A. PENGERTIAN KAJIAN } & 1\end{array}$

B. PENGERTIAN LINGKUNGAN 1

C. KAJIAN LINGKUNGAN 3

D. PENGERTIAN WILAYAH 4

E. PENGERTIAN LOKASI 6

$\begin{array}{ll}\text { F. PENGERTIAN RUANG } & 7\end{array}$

$\begin{array}{ll}\text { BAB II KAJIAN LINGKUNGAN DAN PEMBANGUNAN } & 11\end{array}$

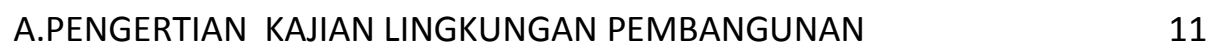

B. PENGERTIAN KAJIAN LINGKUNGAN HIDUP STRATEGIS 11

$\begin{array}{ll}\text { C. KEGUNAAN AMDAL } & 14\end{array}$

D. HUNGUNGAN KAJIAN LINGKUNGAN DENGAN PEMBANGUNAN 16

$\begin{array}{lll}\text { BAB PERENCANAAN PEMBANGUNAN } & 18\end{array}$

III

$\begin{array}{ll}\text { A. PENGERTIAN PERENCANAAN } & 18\end{array}$

$\begin{array}{ll}\text { B. PERENCANAAN PEMBANGUNAN } & 21\end{array}$

C. PERKEMBANGAN PEENCANAAN 23

D. HUBUNGAN PERENCANAAN DENGAN RENCANA 26

$\begin{array}{ll}\text { E. CIRI-CIRI RENCANA YANG BAIK } & 30\end{array}$

F. BENTUK-BENTUK PERENCANAAN 34

$\begin{array}{ll}\text { G. UNSUR-UNSUR PERENCANAAN } & 38\end{array}$

H. HUBUNGAN RENCANA DAN PEMBANGUNAN 43

G. PERENCANAAN YANG BAIK $\quad 50$

BAB IV PERENCANAAN PEMBANGUNAN EKONOMI 52

A. PERLUNYA PERANCANAAN EKONOMI 52

B. MASALAH-MASALAH DALAM PERENCANAAN EKONOMI 52

$\begin{array}{lll}\text { BAB V PERENCANAAN PRODUKSI } & 68\end{array}$ 
$\begin{array}{ll}\text { A. PENGERTIAN PRODUKSI } & 68\end{array}$

$\begin{array}{ll}\text { B. TEORI PRODUKSI } & 70\end{array}$

C. FAKTOR-FAKTOR PRODUKSI

D. TEORI ONGKOS

$\begin{array}{ll}\text { E. MODEL SENTRA PRODUKSI } & 78\end{array}$

$\begin{array}{lll}\text { BAB VI EKONOMI LINGKUNGAN } & 85\end{array}$

A. PENGERTIAN EKONOMI LINGKUNGAN 85

B. PENYEBAB MEROSOTNYA FUNGSI LINGKUNGAN 86

$\begin{array}{ll}\text { C. KEGAGALAN PERENCANAAN PEMERINTAH } & 90\end{array}$

D. NILAI EKONOMI TOTAL $\quad 94$

E. PEMBANGUNAN EKONOMI DAN LINGKUNGAN 99

$\begin{array}{ll}\text { DAFTAR PUSTAKA } & 101\end{array}$ 


\section{BAB I \\ PENDAHULUAN}

\section{A. Pengertian Kajian}

Kata "kajian" berasal dari kata "kaji" yang berarti (1) "pelajaran"; (2) penyilidikan (tentang sesuatu). Bermula dari pengertian kata dasar yang demikian, kata "kajian" menjadi berarti "proses, cara, perbuatan mengkaji; penyelidikan (pelajaran yang mendalam); penelaahan (KBBI 1999: 431). Kata Kajian adalah Kata yang perlu ditelaah lebih jauh lagi maknanya karena tidak bisa langsung dipahami oleh semua orang. Kajian merupakan kata yang dipakai untuk suatu pengkajian atau kepentingan keilmuan. Kajian berarti hasil dari mengkaji. Menurut KBBI, mengkaji artinya belajar, mempelajari, memeriksa, memikirkan, menguji, atau menelaah. Disini dapat dikatakan juga bahwa mengkaji artinya memikirkan sesuatu lebih lanjut yang diharapkan dapat menciptakan suatu kesimpulan yang selanjutnya mengarah untuk melakukan suatu perbuatan.

Dalam setiap kajian, memang tidak selalu menghasilkan suatu kesimpulan. Namun alangkah baiknya, jika hasil berpikir tersebut dapat membuat sesuatu yang berarti. Membuat kajian tidak hanya menguntungkan untuk masyarakat, tetapi juga menguntungkan seseorang yang telah mengkaji. Kajian membuat pola pikir seseorang menjadi terlatih untuk berpikir secara runut, teratur, dan terarah. Semakin sering orang mengkaji, semakin matang dan dewasa hasil-hasil pemikirannya. Jadi kajian merupakan hasil akhir dari suatu upaya pengamatan, penyelidikan, pemahaman dan mendalami serta mengerti yang dikaji dengan melewati berbagai proses untuk pengambilan keputusan.

\section{B. Pengertian Lingkungan}

Lingkungan adalah kombinasi antara kondisi fisik yang mencakup keadaan sumber daya alam seperti tanah, air, energi surya, dan mineral serta flora dan fauna yang tumbuh di atas tanah maupun di dalam lautan, dengan kelembagaan yang 
meliputi ciptaan manusia seperti keputusan bagaimana menggunakan lingkungan fisik tersebut. Lingkungan juga dapat diartikan menjadi segala sesuatu yang ada di sekitar manusia dan mempengaruhi perkembangan kehidupan manusia.

Pengertian Lingkungan Menurut para Ahli : Pengertian Lingkungan Menurut Emil Salim : Lingkungan hidup merupakan segala benda, kondisi, keadaan dan pengaruh yang terdapat dalam ruangan yang kita tempati dan mempengaruhi hal yang hidup termasuk kehidupan manusia. Pengertian Lingkungan Menurut St. Munajat Danusaputra : Lingkungan ialah semua benda dan kondisi termasuk di dalamnya manusia dan aktivitasnya, yang terdapat dalam ruang di mana manusia berada dan mempengaruhi kelangsungan hidup serta kesejahteraan manusia dan jasad hidup lainnya. (Darsono, 1995). Pengertian lingkungan hidup menurut Soedjono yang mengartikan bahwa "lingkungan Hidup" Sebagai "Lingkungan hidup jasmani atau fisik yang meliputi serta mencakup segala unsur dan faktor fisik jasmaniah yang berada didalam alam.

Didalam pengertian ini, maka hewan, tumbuh-tumuhan serta manusia tersebut itu dilihat dan akan dianggap sebagai perwujudan secara fisik jasmani belaka. Dalam hal tersebut "Lingkungan", dapat diartikan sebagai mencakup lingkungan hidup hewan, tumbuh-tumbuhan dan manusia yang terdapat didalamnya. Pengertian lingkungan hidup menurut Undang-undang No 23 pada tahun 1997 yang menyebutkan bahwa Lingkungan hidup ialah suatu kesatuan ruang dengan seluruh benda, daya, keadaan, serta makhluk hidup yang termasuk manusia dan segala perilakuknya yang bisa mempengaruhi segala kelangsungan peri kehidupan dan kesejahteraan manusia serta makhluk hidup yang lainnya. Pengertian Lingkungan Menurut S.J MCNAUGHTON \& LARRY L. WOLF Lingkungan hidup merupakan semua faktor ekstrenal yang bersifat biologis dan fisika yang langsung mempengarui kehidupan, pertumbuhan, perkembangan serta reproduksi organisme. Pengertian Lingkungan Menurut Otto Soemarwoto mengemukakan bahwa dalam bahasa Inggris istilah lingkungan ialah environment. Selanjutnya dikatakan, lingkungan atau lingkungan hidup itu merupakan segala sesuatu yang ada pada setiap makhluk hidup atau organisme serta 
berpengaruh pada kehidupannya. Contohnya, pada hewan seperti kucing, segala sesuatu di sekeliling kucing dan berpengaruh pada keberlangsungan hidup dari kucing tersebut maka itulah yang dinamakan lingkungan hidupnya. Demikian pula pada suatu jenis tumbuhan tertentu, misalnya pohon mangga atau padi di sawah, segala sesuatu yang mempengaruhi pertumbuhan atau kehidupan dari tanaman tersebut itulah yang dimaksud lingkungan hidupnya. Pengertian Lingkungan Menurut JONNY PURBA, Lingkungan hidup ialah wilayah yang merupakan tempat berlangsungnya bermacam-macam interaksi sosial antara berbagai kelompok beserta pranatanya dengan simbol \& nilai.

Jadi Lingkungan merupakan sebuah tempat dimana terdapat komponen abiotik dan biotik serta bisa memberikan banyak manfaat /kebaikan untuk manusia ataupun makhluk hidup lainnya akan tetapi juga bisa memberikan malapetaka /sesuatu yang buruk untuk kehidupan manusia dan makhluk hidup lainnya tergantung dari aktivitas apa yang di lakukan oleh manusia di lingkungan tersebut dan bagaimana manusia tersebut bisa menjaga dan mengelola lingkungan yang sudah ada.

\section{Kajian Lingkungan}

Setiap kajian memang tidak selalu menghasilkan suatu kesimpulan akan tetapi hasil berpikir tersebut dapat membuat sesuatu yang berarti. Kajian membuat pola pikir seseorang menjadi terlatih untuk berpikir secara runut, teratur, dan terarah. Semakin sering orang mengkaji, semakin matang dan dewasa hasil-hasil pemikirannya. Jadi kajian merupakan hasil akhir dari suatu upaya pengamatan, penyelidikan, pemahaman dan mendalami serta mengerti yang dikaji dengan melewati berbagai proses untuk pengambilan keputusan.

Sedangkan Lingkungan merupakan sebuah tempat yang terdapat komponen abiotik dan biotik serta bisa memberikan banyak manfaat /kebaikan untuk manusia ataupun makhluk hidup lainnya akan tetapi juga bisa memberikan malapetaka/sesuatu yang buruk untuk kehidupan manusia dan makhluk hidup lainnya tergantung dari 
aktivitas apa yang di lakukan oleh manusia di lingkungan tersebut dan bagaimana manusia tersebut bisa menjaga dan mengelola lingkungan yang sudah ada.

Kajian lingkungan merupakan kajian untuk memprediksi tempat atau lokasi atau objek tersebut setelah jadi atau sudah berdiri atau tumbuh maupun sudah ada tidak memberikan dampak yang negatif pada manusia, lingkungan abiotik dan biotik serta makluk lain. Di lihat dari sudut pandang perencanaan pembangunan dapat diprediksi yang jauh ke depan sebelum proyek dan kegiatan tersebut akan dilaksanakan.

\section{Pengertian Wilayah}

Wilayah (Region) merepresentasikan unsur lokasi dan ruang dalam perencanaan. Suatu wilayah (region) dalam pengertian geografi, merupakan kesatuan alam yaitu alam yang serbasama atau homogen (uniform), dan kesatuan manusia yaitu masyarakat serta keduanya yang serba sama yang mempunyai ciri yang khas, sehingga wialayah tersebut dapat dibedakan dari wilayah lain. Region ini dapat dikelompokkan; (1) Homogeneus Region, (2) Nodal Regional) dan (3) Administration Region serta (4) Planning Region.

Wilayah adalah sebuah daerah yang dikuasai atau menjadi teritorial dari sebuah kedaulatan. Pada masa lampau, seringkali sebuah wilayah dikelilingi oleh batas-batas kondisi fisik alam, misalnya sungai, gunung, atau laut. Dalam kajian geografi, wilayah atau region diartikan sebagai suatu bagian permukaan bumi yang memiliki karakteristik khusus atau khas tersendiri yang menggambarkan satu keseragaman atau homogenitas sehingga dengan jelas dapat dibedakan dari wilayahwilayah lain di daerah sekitarnya. 


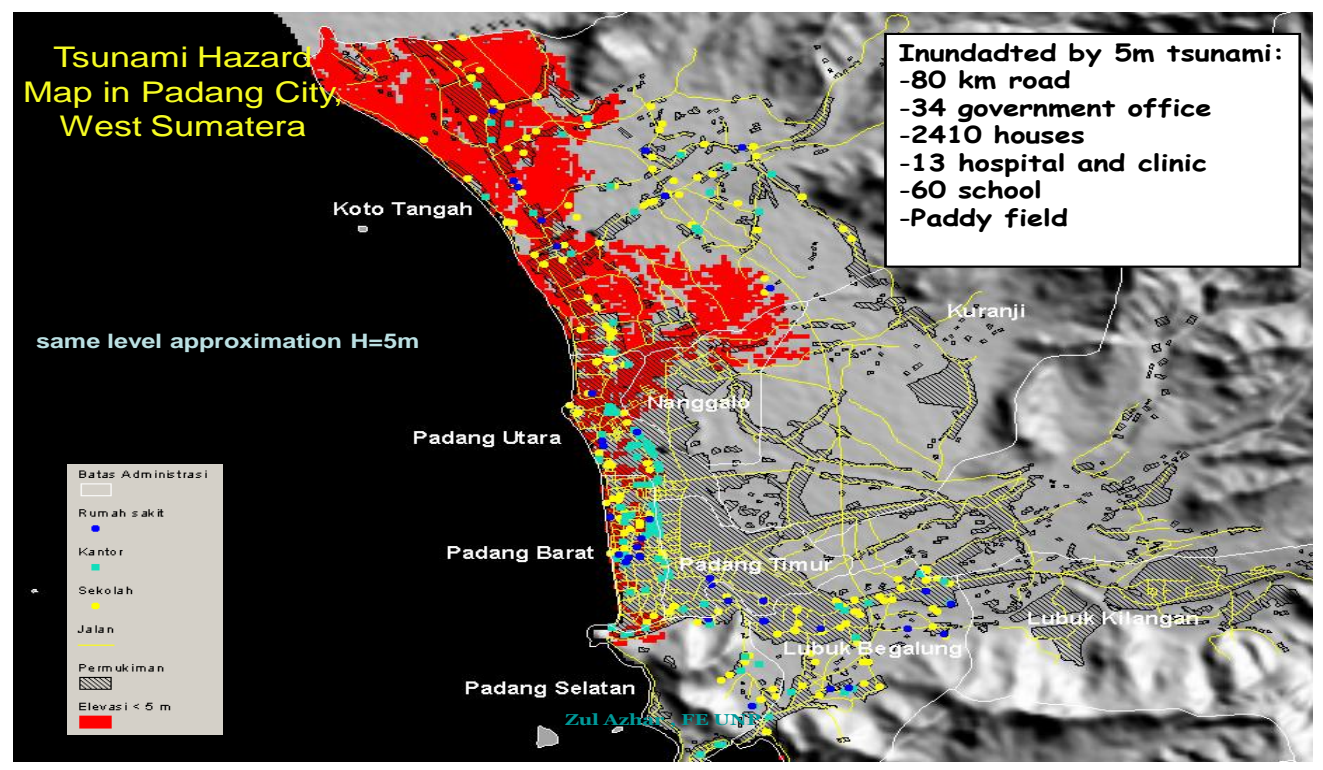

Gambar : 1. Tsunami Hazard Map in Padang City West Sumatera

Sumber : https://www.google.co.id/search?q=wilayah+tsunami+kota+padang

Contohnya, wilayah pantai merupakan bagian dari permukaan bumi yang letaknya di dekat laut dan wilayah pegunungan merupakan bagian permukaan bumi yang letaknya di daerah yang tinggi dan bergunung-gunung. Berikut adalah beberapa konsep wilayah (region) menurut para ahli: Menurut R.E. Dickinson, Wilayah adalah sesuatu yang kondisi fisiknya homogen dan A.J. Heriston, Wilayah adalah komplek tanah, air, udara, tumbuhan, hewan dan manusia dengan hubungan khusus sebagai kebersamaan yang kelangsungannya mempunyai karakter khusus dari permukaan bumi. Fannemar; Wilayah adalah area yang digolongkan melalui kenampakan permukaan yang sama dan dikontraskan dengan area sekitarnya. Taylor, Wilayah dapat didefinisikan sebagai bagian dari permukaan bumi yang berbeda dan ditunjukkan oleh sifat-sifat yang berbeda dan ditunjukkan oleh sifat-sifat yang berbeda dari lainnya.

Menurut Peraturan Pemerintah Nomor 47 Tahun 1997 Tentang Rencana Tata Ruang Wilayah Nasional, Wilayah adalah ruang yang merupakan kesatuan geografis beserta segenap unsur terkait padanya yang batas dan sistemnya ditentukan 
berdasarkan aspek administratif dan/aspek fungsional. Dari beberapa pengertian tersebut dapat disimpulkan bahwa wilayah adalah bagian atau daerah di permukaan bumi yang dibatasi oleh kenampakan tertentu yang bersifat khas dan membedakan wilayah tersebut dari wilayah lainnya. Misalnya, wilayah hutan berbeda dengan wilayah pertanian, wilayah kota berbeda dengan wilayah perdesaan. Terkadang kita sering menyamakan antara tempat (place) dan wilayah (region). Tempat dan wilayah sama-sama menunjukkan lokasi tetapi keduanya berbeda dalam pengertian. Tempat merupakan bagian ruang di Bumi, baik berukuran luas atau sempit yang bermanfaat bagi kehidupan manusia. Wujud tempat dapat berupa benua, pulau, negara, kota, desa, dusun, dan daerah tidak berpenghuni. Tempat tersebut biasanya mempunyai nama dan batas-batas serta ciri-ciri yang bersifat fisik maupun sosial. Ciri fisik suatu tempat misalnya iklim, bentuk lahan, tanah, hidrosfer, flora, dan fauna. Ciri sosial suatu tempat misalnya bahasa, agama, sistem ekonomi, sistem politik, dan penyebaran penduduk. Wilayah merupakan suatu konsep yang digunakan untuk mengidentifikasi dan mengorganisasi daerah (area) di muka Bumi untuk berbagai tujuan. Suatu wilayah mempunyai karakteristik tertentu yang memberikan ukuranukuran kesamaan dan perbedaan dengan wilayah lain. Contoh: Perbedaan wilayah pesisir dan pedalaman. Wilayah dapat digunakan untuk menyederhanakan daerah di muka Bumi dengan pengaturan berdasarkan pada karakteristik fisik dan sosial yang ada. Wilayah dibangun manusia sebagai suatu hasil kreasi dan mempunyai batasbatas yang diturunkan dari kriteria khusus.

\section{E. Pengertian Lokasi}

Menurut Buchari Alma (2003:103) mengemukakan bahwa "Lokasi adalah tempat perusahaan beroperasi atau tempat perusahaan melakukan kegiatan untuk menghasilkan barang dan jasa yang mementingkan segi ekonominya". Ujang Suwarman (2004:280),'Lokasi merupakan tempat usaha yang sangat mempengaruhi keinginan seseorang konsumen untuk datang dan berbelanja”. Kasmir (2009:129) Lokasi adalah "Tempat melayani konsumen, dapat pula diartikan sebagai tempat 
untuk memajangkan barang barang dagangannya". Fandy Tjiptono (2002:92) "Lokasi adalah tempat perusahaan beroperasi atau tempat perusahaan melakukan kegiatan untuk menghasilkan barang dan jasa yang mementingkan segi ekonominya.” Levy (2007 : 213) "Lokasi itu sendiri merupakan perencanaan dan pelaksanaan program penyaluran produk atau jasa melalui tempat atau lokasi yang tepat.” Lupiyoadi (2009) mengemukakan bahwa "Lokasi adalah tempat dimana perusahaan harus bermarkas melakukan operasi". Swastha (2009) "Lokasi adalah tempat dimana suatu usaha atau aktivitas usaha dilakukan”. Heizer \& Render (2015) lokasi adalah pendorong biaya dan pendapatan, maka lokasi seringkali memiliki kekuasanaan untuk membuat strategi bisnis perusahaan. Lokasi yang strategis bertujuan untuk memaksimalkan keuntungan dari lokasi bari perusahaan. Kotler (2008) Salah satu kunci menuju sukses adalah lokasi, lokasi dimulai dengan memilih komunitas. Keputusan ini sangat bergantung pada potensi pertumbuhan ekonomis dan stabilitas, persaingan, iklim politik, dan sebagainya.Teori Lokasi dari August Losch (dalam Sofa, 2008) "melihat persoalan dari sisi permintaan (pasar)". Losch mengatakan bahwa "lokasi penjual sangat berpengaruh terhadap jumlah konsumen yang dapat digarapnya. Makin jauh dari tempat penjual, konsumen semakin enggan membeli karena biaya transportasi untuk mendatangi tempat penjual semakin mahal”.

\section{F. Pengertian Ruang}

Ruang (spatial) adalah wadah yang meliputi ruang darat, ruang laut, dan ruang udara, termasuk ruang di dalam bumi sebagai satu kesatuan wilayah, tempat manusia dan makhluk lain hidup, melakukan kegiatan, dan memelihara kelangsungan hidupnya. Ruang juga dapat didefinisikan dalam perspektif fisik sebagai berikut: Wujud fisik wilayah dalam dimensi geografis dan geometris yang merupakan wadah bagi manusia melaksanakan kegiatan kehidupannya dalam suatu kualitas lingkungan hidup yang layak. Yang termasuk dalam unsur ruang adalah jarak, kondisi geografis, tata-guna lahan dan perbedaan kondisi sosial-ekonomi wilayah, Aspek ruang menjadi 
sangat penting pada negara dengan wilayah luas dengan kondisi beragam, ruang ditampilkan dalam bentuk peta.
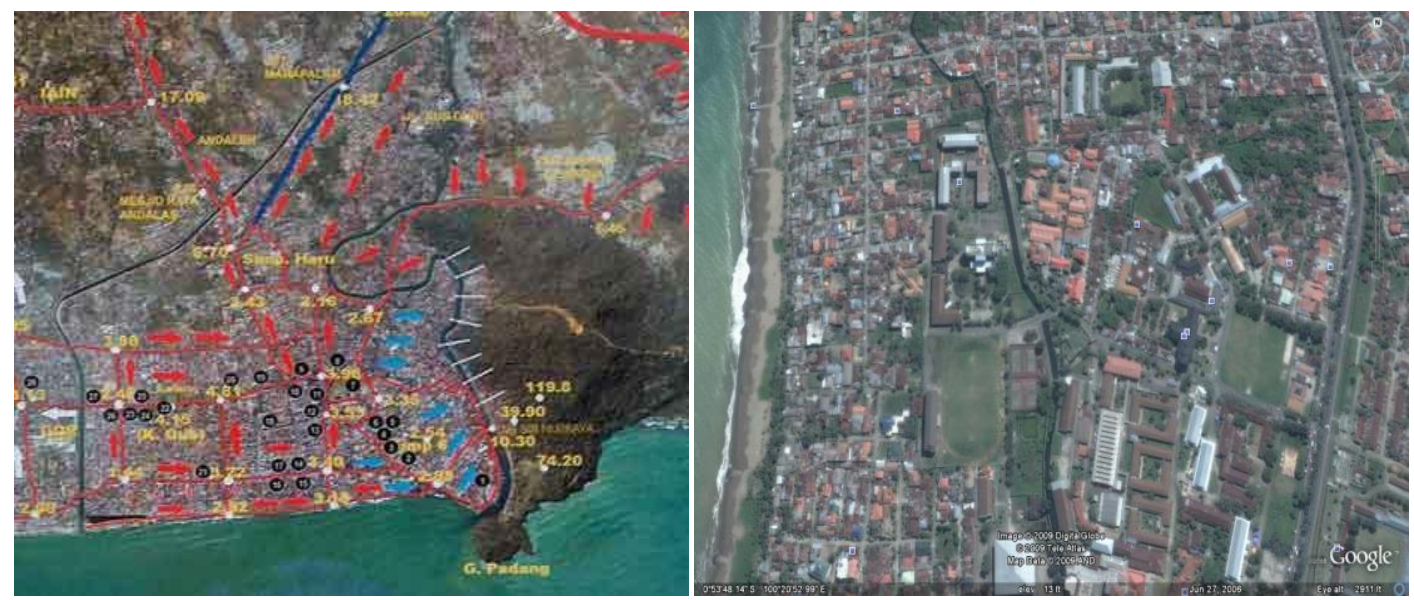

Gambar 2 Ruang Dalam Bentu Google Map

Sumber : https://www.google.co.id/search?q=wilayah+tsunami+kota+padang

Ruang merupakan salah satu komponen penting dalam kehidupan manusia. Ruang sangat terkait erat dengan waktu. Karena sangat pentingnya ruang dan waktu bagi kehidupan manusia, maka filsafat ruang dan waktu telah menjadi perdebatan sejak ribuan tahun yang lalu. Keterkaitan yang sangat erat antara ruang dan waktu, dalam ilmu Fisika, keduanya kemudian digabung menjadi ruangwaktu atau ruangwaktu dalam suatu kontinum. Ruang-waktu biasanya ditafsirkan dengan ruang yang tiga- dimensi dan waktu memainkan peran sebagai dimensi keempat. Pada ilmu pengembangan ekonomi lokal, seperti ilmu ekonomi berbasis wilayah lainnya, ruang mempunyai posisi yang sangat sentral, dan ruang inilah yang merupakan pembeda utama dengan ekonomi konvensional.

Padahal sudah jelas bahwa analisis ekonomi apapun yang diletakan pada alam tanpa ruang, amat jauh dari kenyataan hidup. Sumbangan terbesar tentang filsafat ruang dan waktu berasal dari filsuf Islam, seperti: Al-Kindi (801-873 M), Al Ghazali 1058-19 December 1111 M), dan Ibnu Haitham atau Alhazen (965-1040 H). Karyakarya mereka merupakan inspirasi bagi filsuf-filsuf Barat seperti Immanuel Kant. 
Isaac Newton, ruang adalah absolut dalam arti bahwa ia ada secara permanen dan independen.

Perkembangan Filsafat Ruang Abad 19-20. Pada abad ke 19 dan 20, matematikawan mulai mengkaji Geometri Non-Euclidean, dimana ruang dapat dikatakan melengkung, bukan datar. Menurut teori Eistein tentang Relativitas Umum, bahwa ruang di sekitar medan gravitasi menyimpang dari ruang Euclidean. • Michael Foucault yang menyatakan bahwa abad 19 adalah abad waktu, ruang tak bergerak, ajeg dan mati. Zaman ruang akan terjadi pada abad 20, dimana ruang akan aktif, bergerak, dan subur. Kalau mengikuti pola piker Foucault tersebut, maka abad ke-21 ini, merupakan abad ruang-waktu, menjalin ruang dan waktu. - Perkembangan pemikiran tentang ruang pada era abad banyak dipengaruhi oleh pemikiran Karl Marx. Henri Lefebvre merupakan filsuf dari Perancis yang memulai kerja tentang ruang berdasarkan pemikiran Karl Marx. Karya-karya Lefebvre kemudian menjadi inspirasi bagi penerusnya seperti Edward W. Soja, David Harvey dan Rob Shield.

Konsep Ruang Menurut Lefebvre. Menurut Lefebvre, ruang diproduksi dalam masyarakat melalui proses triadic terdiri dari "Ruang Praktik", "Representasi Ruang," dan "Representasional Ruang atau Ruang Representasi. Ruang Praktik (perçu Espace atau ruang yang dapat dirasakan) yaitu ruang yang dihasilkan oleh produksi dan reproduksi kapitalis, yang merupakan hasil dari kegiatan dan perilaku dan pengalaman manusia atau merupakan bentuk ruang secara fisik, ruang nyata, ruang yang dihasilkan dan digunakan. Representasi ruang (conçu Espace, ruang dipahami) adalah representasi hegemonik ideologis terkait dengan ruang atau dapat juga dikatakan sebagai ruang savoir (pengetahuan) dan logika atau ruang sebagai konstruksi mental atau ruang dalam alam pikiran (dibayangkan) yang merupakan representasi kekuasaan, ideologi, kontrol, dan pengawasan. Representasional ruang atau ruang representasi (Vécu Espace, ruang hidup) terkait dengan gerakan perlawanan melakukan hal itu atau melihat ruang sebagai sesuatu yang diproduksi dan dimodifikasi sepanjang waktu dan melalui penggunaannya, ruang diinvestasikan 
dengan simbolisme dan makna, ruang dari connaissance (kurang lebih formal atau bentuk-bentuk pengetahuan lokal), ruang sebagai sesuatu nyata-dan-dibayangkan.

Konsep Ruang Edward Soja mengembangkan tiga konsep yang penting untuk dapat memahami idenya tentang Ruang Ketiga (Thirdspace). Konsep yang pertama adalah Thirding-as-Othering, yang kedua dan ketiga adalah dua trialektika, yaitu Ontologis dan Epistomologis, Ontologis yaitu trialectics of being: kesejarahan (historicality), kesosialan (sociality) dan keruangan (spatiality). Epistomologistrialectics of spatiality: ruang dirasakan (perceived space), ruang dipahami (conceived space), dan ruang hidup (lived space). Konsep Ruang Ketiga dari Soja ini melampaui Konsep Marxismenya Lefebvre dalam upaya untuk merangkul kelompok atau individu yang terpinggirkan dan kehilangan haknya, yang terus-menerus termarjinalkan karena keruangan mereka diabaikan. 


\section{BAB II}

\section{KAJIAN LINGKUNGAN DAN PEMBANGUNAN}

\section{A. Pengertian Kajian Lingkungan dan Pembangunan}

Pengertian Kajian Lingkungan dan Pembangunan merupakan kajian lingkungan yang dikaji dampak posif dan negatif untuk dapat diprediksi akan muncul setelah pembangunan dimanfaatkan. Sehingga untuk memprediksi tempat atau lokasi atau objek tersebut setelah jadi atau sudah berdiri atau tumbuh maupun sudah ada tidak memberikan dampak yang negatif pada manusia, lingkungan abiotik dan biotik serta makluk lain. Hubungan Kajian Lingkungan dengan Pembangunan sudut pandang perencanaan pembangunan dapat diprediksi yang jauh ke depan sebelum proyek dan kegiatan tersebut akan dilaksanakan.

Kajian Lingkungan dan Pembangunan sangat berbeda dengan AMDAL (Analisis Dampak Lingkungan). AMDAL juga menganalisis lingkungan tidak sejauh dan sedalam jaian lingkungan, akan tetapi kajian lingkungan harus bisa membuat prediksi positif ke depan dan miminalkan dampak negatif. Sementara bisa dikatakan bahwa AMDAL persyarakat untuk mendirikan atau melakukan sesuatu di lokasi yang direncanakan.

Contoh kasus LAPINDO di Jawa Tengah, Basko Moll di Padang, Proyek Trotoal dan Dranaise yang setelah terbagun muncul masalah. Pada hal setiap kegiatan atau proyek akan dibangun harus ada AMDAL, seharusnya tidak terjadi hal seperti itu. Untuk itu banyak kajian lingkungan yang lain yang bisa didiskusikan.

\section{B. Pengertian Kajian Lingkungan Hidup Strategis (KLHS)}

Aspek lingkungan dalam penataan wilayah memang sangat penting, meskipun peraturan penataan ruang telah memasukkan unsur-unsur pengelolaan lingkungan dalam aturan dan petunjuk pelaksanaan penataan ruang tetapi belum mampu diaplikasikan mengingat beragamnya kondisi yang ada di setiap wilayah Indonesia. Wilayah pantai, rawa, dataran rendah, perukitan dan wilayah pegunungan akan 
memiliki cara berbeda dalam rangka melakukan upaya penyelamatan lingkungan menuju pembangunan yang lestari. Wilayah hutan alami, hutan sekunder, savanah dan wilayah karst akan juga berbeda perencanaan ruangnya. Perbedaan ini hanya bisa dilakukan dengan melakukan perencanaan ruang dengan mengaplikasikan KLHS.

Pemerintah dalam hal ini pemerintah daerah wajib membuat KLHS untuk memastikan bahwa prinsip pembangunan berkelanjutan telah menjadi dasar dan terintegrasi dalam pembangunan suatu wilayah dan/atau kebijakan, rencana, dan/atau program. Apa itu KLHS ?. Kajian Lingkungan Hidup Strategis (KLHS) adalah kajian yang harus dilakukan pemerintah daerah sebelum memberikan izin pengelolaan lahan maupun hutan. KLHS tertuang dalam UU No 32 Tahun 2009 Tentang Perlindungan dan Pengelolaan Lingkungan Hidup. Pembuatan KLHS ditujukan untuk memastikan penerapan prinsip pembangunan berkelanjutan dalam pembangunan suatu wilayah, serta penyusunan kebijakan dan program pemerintah. Menurut undang-undang tentang perlindungan dan pengelolaan lingkungan hidup, KLHS harus dilakukan dalam penyusunan dan evaluasi rencana tata ruang wilayah, rencana pembangunan jangka menengah dan panjang, kebijakan dan program yang berpotensi menimbulkan dampak dan atau risiko terhadap lingkungan hidup. Mekanisme pelaksanaan KLHS meliputi pengkajian pengaruh kebijakan, rencana, dan program terhadap kondisi lingkungan hidup di suatu wilayah, perumusan alternatif penyempurnaan kebijakan dan program serta rekomendasi perbaikan untuk pengambilan keputusan kebijakan dan program yang mengintegrasikan prinsip pembangunan berkelanjutan. KLHS sendiri menurut ketentuan harus memuat kajian mengenai kapasitas daya dukung dan daya tampung lingkungan hidup untuk pembangunan; perkiraan mengenai dampak dan risiko terhadap lingkungan hidup.

Menurut Sadler dan Verheem (1996), KLHS adalah proses sistematis untuk mengevaluasi konsekuensi lingkungan hidup dari suatu usulan kebijakan, rencana, atau program sebagai upaya untuk menjamin bahwa konsekuensi dimaksud telah dipertimbangkan dan dimasukan sedini mungkin dalam proses pengambilan keputusan paralel dengan pertimbangan sosial dan ekonomi dan Therieveletal (1992), 
KLHS adalah proses yang komprehensif, sistematis dan formal untuk mengevaluasi efek lingkungan dari kebijakan, rencana, atau program berikut alternatifnya, termasuk penyusunan dokumen yang memuat temuan evaluasi tersebut dan menggunakan temuan tersebut untuk menghasilkan pengambilan keputusan yang memiliki akuntabilitas publik. Mengapa perlu KLHS, hal ini ada banyak alasan menjadi penting, diataranya; meningkatkan manfaat pembangunan, rencana dan implementasi pembangunan lebih terjamin keberlanjutannya, Mengurangi kemungkinan kekeliruan dalam membuat prakiraan/prediksi pada awal proses perencanaan kebijakan, rencana, atau program pembangunan, dampak negatif lingkungan di tingkat proyek pembangunan semakin efektif diatasi atau dicegah karena pertimbangan lingkungan telah dikaji sejak tahap formulasi kebijakan, rencana, atau program pembangunan.

Bebebrapa nilai-nilai yang dianggap penting dalam aplikasi KLHS di Indonesia adalah Keterkaitan (interdependency); digunakan sebagai nilai penting dalam KLHS dengan maksud agar dalam penyelenggaraan KLHS mempertimbangkan keterkaitan antara satu komponen dengan komponen lain, antara satu unsur dengan unsur lain, atau antara satu variabel biofisik dengan variabel biologi, atau keterkaitan antara lokal dan global, keterkaitan antar sektor, antar daerah, dan seterusnya. Dengan membangun pertautan tersebut maka KLHS dapat diselenggarakan secara komprehensif atau holistik.

Keseimbangan (equilibrium); digunakan sebagai nilai penting dalam KLHS dengan maksud agar penyelenggaraan KLHS senantiasa dijiwai atau dipandu oleh nilai-nilai keseimbangan seperti keseimbangan antara kepentingan sosial ekonomi dengan kepentingan lingkungan hidup, keseimbangan antara kepentingan jangka pendek dan jangka panjang, keseimbangan kepentingan pembangunan pusat dan daerah, dan lain sebagainya. Implikasinya, forum-forum untuk identifikasi dan pemetaan kedalaman kepentingan para pihak menjadi salah satu proses dan metode yang penting digunakan dalam KLHS.

Keadilan (justice); digunakan sebagai nilai penting dengan maksud agar melalui KLHS dapat dihasilkan kebijakan, rencana dan program yang tidak mengakibatkan 
marginalisasi sekelompok atau golongan masyarakat tertentu karena adanya pembatasan akses dan kontrol terhadap sumber- sumber alam atau modal atau pengetahuan. Kegiatan penyusunan KLHS di Indonesia harus mengacu pada UU No. 32 Tahun 2009 tentang Perlindungan dan Pengelolaan Lingkungan Hidup (PPLH) dan Peraturan Menteri Negara Lingkungan Hidup No. 27 Tahun 2009 Pedoman Pelaksanaan KLHS.Pentingnya KLHS akan mampu memperbaiki mutu dan proses formulasi substansi RTRW, memfasilitasi proses pengambilan keputusan dalam proses perencanaan agar dapat menyeimbangkan tujuan lingkungan hidup, dengan tujuan sosial dan ekonomi. KLHS dimungkinkan untuk mampu meminimasi potensi dampak penting negatif akibat usulan RTRW jika tingkat keberlanjutan substansi RTRW rendah, serta melakukan langkah-langkah perlindungan yang tangguh-jika tingkat keberlanjutan substansi RTRW moderat dan memelihara potensi sumber daya alam dan daya dukung air, udara, tanah dan ekosistem. Dengan demikian pelaksanaan KLHS dilaksanakan dengan mekanisme pengkajian pengaruh kebijakan, rencana, dan/atau program terhadap kondisi lingkungan hidup di suatu wilayah; perumusan alternatif penyempurnaan kebijakan, rencana, dan/atau program; dan rekomendasi perbaikan untuk pengambilan keputusan kebijakan, rencana, dan/atau program yang mengintegrasikan prinsip pembangunan berkelanjutan.

\section{Kegunaan Analisis Dampak Lingkungan (AMDAL)}

AMDAL adalah kajian mengenai dampak besar dan penting untuk pengambilan keputusan suatu usaha dan/atau kegiatan yang direncanakan pada lingkungan hidup yang diperlukan bagi proses pengambilan keputusan tentang penyelenggaraan usaha dan/atau kegiatan (Peraturan Pemerintah No. 27 tahun 1999 tentang Analisis Mengenai Dampak Lingkungan).

Kegunaan AMDAL adalah untuk bahan bagi perencanaan pembangunan wilayah, membantu proses pengambilan keputusan tentang kelayakan lingkungan hidup dari rencana usaha dan/atau kegiatan, memberi masukan untuk penyusunan 
disain rinci teknis dari rencana usaha dan/atau kegiatan, memberi masukan untuk penyusunan rencana pengelolaan dan pemantauan lingkungan hidup serta memberi informasi bagi masyarakat atas dampak yang ditimbulkan dari suatu rencana usaha dan atau kegiatan. Akan tetapi memberikan alternatif solusi minimalisasi dampak negatif, digunakan untuk mengambil keputusan tentang penyelenggaraan/pemberi ijin usaha dan/atau kegiatan.

AMDAL harus dilakukan dengan dua macam cara sebagai berikut;

a. AMDAL harus dilakukan untuk proyek yang akan dibangun karena UndangUndang dan Peraturan-Peraturan Pemerintah menghendaki demikian. Apabila pemilik atau pemrakarsa proyek tidak melakukannya maka akan melanggar undang-undang dan besar kemungkinan perizinan untuk pembangunan proyek tersebut tidak akan didapat, atau akan menghadapi pengadilan yang dapat memberikan sanksisanksi yang tidak ringan. Cara ini cukup efektif untuk memaksa para pemilik proyek yang kurang memperhatikan kualitas lingkungan atau pemilik proyek yang hanya mementingkan keuntungan proyeknya sebesar mungkin tanpa menghiraukan dampak sampingan yang timbul. Tanpa adanya undang-undang, peraturan pemerintah, dan Pedomanpedoman Baku Mutu maka dasar hukum dari pelaksanaan AMDAL ini tidak ada.

b. AMDAL harus dilakukan agar kualitas lingkungan tidak rusak karena adanya proyek-proyek pembangunan. Cara kedua ini merupakan yang ideal, tetapi kesadaran mengenai masalah ini tidak mudah ditanamkan pada setiap orang terutama para pemrakarsa proyek. Manusia dalam usahanya memenuhi kebutuhan dan meningkatkan kesejahteraannya telah melakukan berbagai aktivitas dari bentuk yang sederhana sampai yang sangat canggih, mulai dari bangunan yang kecil sampai yang sangat besar dan canggih, mulai dari yang hanya sedikit saja mengubah sumber daya alam dan lingkungan sampai yang menimbulkan perubahan yang besar. 


\section{Hubungan Kajian Lingkungan dengan Pembangunan}

AMDAL adalah singkatan dari Analisis Mengenai Dampak Lingkungan. Dalam Peraturan Pemerintah Nomor 27 tahun 1999, AMDAL merupakan kajian mengenai dampak besar dan penting untuk pengambilan suatu usaha dan/atau kegiatan yang direncanakan pada lingkungan hidup. Dalam melakukan inovasi atas lingkungan hidup, tak bisa begitu saja merubah tatanan alam tanpa proses yang berlaku. Di Indonesia kita mengenal tiga jenis izin yang harus dilewati sebelum memulai aktivitas yang dapat mengubah kondisi alam dan lingkungan hiudp, yaitu AMDAL, KLHS, dan izin lingkungan.

Dari AMDAL, dihasilkan perbandingan dampak positif dan negatif dari sebuah pekerjaan untuk merubah tatanan lingkungan. Jika dampak positif lebih banyak dari dampak negatif, berarti perubahan tersebut bisa diteruskan. Sebaliknya, jika tidak layak, sebuah proyek harus dihentikan. Selain AMDAL, satu kajian yang harus dilakukan sebagai proses perubahan lingkungan hidup karena sebuah proyek adalah Kajian Lingkungan Hidup Strategis atau KLHS. KLHS ini dijalankan oleh pemerintah daerah dan tertuang dalam Undang-undang Nomor 23 tahun 2009.

KLHS berperan sebagai hasil yang mengevaluasi Rencana Tata Ruang Wilayah (RTRW), pembangunan jangka panjang dan menengah, serta kebijakan dan program yang berpotensi menimbulkan dampak atau resiko terhadap lingkungan hidup. Dengan kata lain, rencana yang telah dikaji pada AMDAL, dievaluasi lewat KLHS secara berkala.Setelah AMDAL dan KLHS, kita mengenal izin lingkungan sebagai tahap akhir perihal boleh atau tidaknya seseorang melakukan usaha atau kegiatan di satu area lingkungan hidup. Maka, syarat wajib dari keluarnya izin lingkungan oleh pemerintah provinsi adalah AMDAL.Dalam kasus reklamasi di teluk Jakarta, pemerintah provinsi DKI Jakarta telah mengeluarkan AMDAL. Namun belum ada KLHS atau Izin lingkungan yang terbit hingga hari ini. Meski begitu, beberapa pulau ada yang sudah selesai atau diproses secara bertahap. 
Dalam "Rekomendasi Tim Bidang Teknis dan Kebijakan Reklamasi Pantai Utara Jakarta" yang disusun oleh Koalisi Selamatkan Teluk Jakarta, di Pulau C, sudah ada kegiatan reklamasi seluas 40 persen dari target izin.Pulau D telah direklamasi 100 persen. Pulau G telah direklamasi kurang lebih 20 persen. Pulau K sudah memiliki tanggul pulau, begitu juga pulau L. Pulau N pun sudah memiliki konstruksi tiang $\begin{array}{llll}\text { pancang dan } & \text { (Andi/Billy). Sumber }\end{array}$ https://www.indopress.id/article/serbaserbi/begini-perbedaan-amdal-klhs-dan-izinlingkungan.

Untuk itu hubungan antara kajian lingkungan dengan pembangunan harus ibarat kapal mau berlayar, seharusnya semua pihak berkepentingan mempunyai tanggung jawab berlayar agar janga sama tengeam, begitu juga dalam pembangunan. Maka di kaji dengan matang imfact negatif dan positif dari suatu proyek atau suatu kegiatan pembangunan tersebut yang diprediksi jauh kedepan baik jangka pendek maupun jangka panjang. 


\section{BAB III}

\section{PERENCANAAN PEMBANGUNAN}

\section{A. Pengertian Perencanaan}

Perencanaan (Planning) diderevatif dari fungsi manajemen yaitu POAC (Panning, Organizing, Actating and Controling). Menurut D. Conyers dan Hills (1984), Perencanaan adalah proses yang kontinyu, terdiri dari keputusan atau pilihan dari berbagai cara untuk menggunakan sumber daya yang ada, dengan sasaran untuk mencapai tujuan tertentu di masa mendatang. Sedangkan menurut MT Todaro (Economic Development, 7 th ed., 2000); Perencanaan Ekonomi adalah upaya pemerintah secara sengaja untuk mengkoordinir pengambilan keputusan ekonom dalam jangka panjang serta mempengaruhi, mengatur dan dalam beberapa hal mengontrol tingkat dan laju pertumbuhan berbagai variable ekonomi yang utama untuk mencapai tujuan pembangunan yang telah ditentukan sebelumnya. Selanjutnya menurut Jhingan; Perencanaan adalah teknik/cara untuk mencapai tujuan, untuk mewujudkan maksud dan sasaran tertentu yang telah ditentukan sebelumnya dan telah dirumuskan dengan baik oleh Badan Perencana Pusat. Tujuan tersebut mungkin untuk mencapai sasaran social, politik atau lainnya.

Arti pentingnya perencanaan yaitu merencanakan berarti memilih; Memilih berbagai alternatif tujuan agar tercapai kondisi yang lebih baik. Memilih cara/kegiatan untuk mencapai tujuan/sasaran dari kegiatan tersebut. Perencanaan sebagai alat untuk mengalokasikan sumber daya: SDA, SDM, Modal. Sumber daya terbatas sehingga perlu dilakukan pengalokasian sumber daya sebaik mungkin.Konsekuensi: pengumpulan dan analisis data dan informasi mengenai ketersediaan sumber daya yang ada menjadi sangat penting. Perencan harus ber motto “Plan what you do, and do what you plan".

Perencanaan sebagai alat untuk mencapai tujuan /sasaran. Beberapa masalah

yang dihadapi dalam pembuatan tujuan antara lain; Tujuan tidak terdefinisikan 
dengan baik, tujuan tidak realistik, perencanaan cenderung lebih dari satu tujuan, kadang tidak konsisten satu sama lain, tujuan dipertanyakan atau tidak sesuai dengan tujuan pengambil keputusan lain (Mis: DPRD), perencanaan berhubungan dengan masa yang akan datang, yang berkaitan dengan: Proyeksi/prediksi.

Perencanaan dapat diumpamakan sebagai suatu jembatan yang menjadi penghubung antara masa sekarang dengan masa datang yang hendak dituju. Sekiranya jembatan itu hendak dibangun, berarti kita telah mengetahui dimana kita berada, apa-apa yang harus dilakukan dan kemana kita hendak pergi. Dengan demikian, suatu perencanaan merupakan tindakan pengambilan keputusan di depan, mengenai apa, bagaimana, bilamana, dan siapa yang berkaitan dengan sesuatu kegiatan dalam mencapai tujuannya.

Untuk merumuskan suatu perencanaan seringkali ditemui berbagai kesulitan, terutama dalam mengahadapi faktor manusia dan meramalkan kejadian masa datang. Faktor manusia itu meliputi baik dalam arti oknum, pelaksana, kelompok, masyarakat maupun diri pribadi sendiri. Seseorang bisa jujur tetapi sulit dipegang janjinya atau seseorang bisa jujur dan dapat dipegang janjinya akan tetapi tidak cocok dengan tugas-tugasnya. Sementara itu, peramalan kejadian masa datang hanya bisa dilihat kemungkinan-kemungkinannya, yang diperoleh atas dasar informasi masa lalu dan masa sekarang. Data dan informasi tersebut seringkali diragukan keakuratannya. Begitu pula, kemampuan piranti analisa yang digunakan dan kemampuan sebagai manusia yang terbatas menyebabkan kejadian yang pasti dimasa datang merupakan hal yang tidak mungkin diramalkan secara tepat.

Seseorang akan berusaha untuk mengetahui masa datang, melihat sejauhjauhnya, untuk menguatkan pengharapannya. Tanpa memiliki suatu pengharapan, seseorang akan hidup dalam kebingungan atau pasif sama sekali, sehingga tidak memiliki semangat berjuang untuk menempuh kehidupannya. Sebaliknya, jika seseorang mempunyai pengharapan masa depan yang terlalu besar, maka 
kemungkinan hal tersebut akan bisa mendatangkan kekecewaan yang sangat besar pula. Jadi dalam memperkirakan keadaan masa datang itu cukup sewajarnya, yang diramalkan berdasarkan kenyataan-kenyataan yang ada dan kemampuankemampuan yang dimiliki.

Meskipun demikian kualitas dari suatu perencanaan masih dapat ditingkatkan. Peningkatan itu dilakukan melalui penggunaan data dan informasi yang tepat dan akurat serta penggunaan piranti analisa yang canggih disamping meningkatkan kemapuan dari perencana. Apabila seseorang ingin untuk mengembangkan kemampuannya dalam merumuskan suatu perencanaan, mau tidak mau dia harus melatih diri untuk berpikir secara sistematis (systematic thinking) dalam mengetahui dan menganalisa masalah-masalah yang dihadapi (identification of problems) agar memiliki keberanian untuk memilih alternatif terbaik sebab tanpa keputusan, berarti tidak akan ada aktivitas. Kebiasaan melatih diri itu akan dapat meningkatkan intuisi dari perencana, yang sangat bermanfaat untuk merumuskan suatu perencanaan. Suatu kenyataan bahwa keberhasilan perencanaan sering kali tergantung kepada intuisi yang baik dari perencana yang dapat diaplikasikan secara kuantitatif.

Pada hakekatnya pengertian pembangunan secara umum pada hakekatnya adalah proses perubahan yang terus menerus untuk menuju keadaan yang lebih baik berdasarkan norma-norma tertentu. Mengenai pengertian pembangunan, para ahli memberikan definisi yang bermacam-macam seperti halnya perencanaan. Istilah pembangunan bisa saja diartikan berbeda oleh satu orang dengan orang lain, daerah yang satu dengan daerah lainnya, Negara satu dengan Negara lain. Namun secara umum ada suatu kesepakatan bahwa pembangunan merupakan proses untuk melakukan perubahan (Riyadi dan Deddy Supriyadi Bratakusumah, 2005).

Untuk lebih jelasnya berikut ini disajikan pengertian pembangunan menurut beberapa ahli; Siagian (1994) memberikan pengertian tentang pembangunan sebagai "Suatu usaha atau rangkaian usaha pertumbuhan dan perubahan yang berencana dan 
dilakukan secara sadar oleh suatu bangsa, negara dan pemerintah, menuju modernitas dalam rangka pembinaan bangsa (nation building)". Sedangkan Ginanjar Kartasasmita (1994) memberikan pengertian yang lebih sederhana, yaitu sebagai "suatu proses perubahan ke arah yang lebih baik melalui upaya yang dilakukan secara terencana". Pembangunan (development) adalah proses perubahan yang mencakup seluruh system sosial, seperti politik, ekonomi, infrastruktur, pertahanan, pendidikan dan teknologi, kelembagaan, dan budaya (Alexander 1994). Portes (1976) mendefinisiskan pembangunan sebagai transformasi ekonomi, sosial dan budaya. Sama halnya dengan Portes, Menurut Deddy T. Tikson (2005) bahwa pembangunan nasional dapat pula diartikan sebagai transformasi ekonomi, sosial dan budaya secara sengaja melalui kebijakan dan strategi menuju arah yang diinginkan. Sedangkan dalam pengertian ekonomi murni, pembangunan adalah suatu usaha proses yang menyebabkan pendapatan perkapita masyarakat meningkat dalam jangka panjang. (Sukirno, 1995:13).

\section{B. Perencanaan Pembangunan}

Ruang lingkup materi buku ajar perencanaan pembangunan ini mengedepankan tentang konsep-konsep dasar perencanaan yang mencakup tentang perkembangan konsep perencanaan, arti begitu pentingnya suatu perencanaan, ciri-ciri rencana yang baik dan bentuk-bentuk perencanaan.

Perencanaan adalah suatu proses yang berkesinambungan (Kontinu), berkelanjutan, sejak dari tahap survei sampai pada tahap pengamatan. Dalam hal ini perencanaan fisik merupakan bagian atau alat organisasi masyarakat dan pengawasan atau kontrol penggunaan tanah. Untuk sampai kepada penuntun alternatif rencana dan penyusunan kebijakan pelaksanaan, haruslah melalui beberapa tahap kegiatan dalam proses perencanaan. Dalam kenyataannya, proses perencanaan merupakan suatu kegiatan yang tidak pernah selesai, karena selalu memerlukan peninjauan ulang atau pengkajian, guna memberi kan balikan dalam proses penilaan. Ini berlaku pula apabila sudah sampai pada 
tahap pelaksanaan. Setelah proses ini, tidak mustahil harus diambil berbagai langkah penyempurnaan rencana bagi pelaksanaan selanjutnya. Dalam proses penentuan alternatif, pemilihan alternatif dan evaluasi inilah memerlukan analisis yang seksama.

Analisis adalah uraian atau usaha mengetahui arti suatu keadaan. Data atau bahan keterangan mengenai suatu keadaan diurai dan diselidiki hubungan dan kaitan yang ada antara yang satu dengan yang lain. Analisis wilayah (regional) ialah cara melihat berbagai faktor perkembangan dalam skala wilayah. Dalam hal analisis daerah, daerah dapat didefinisikan sebagai suatu wilayah yang ditentukan oleh beberapa faktor, yaitu tujuan, skala, dan proses (Ginsburg, 1958). Tujuan sangatlah berpengaruh dalam perencanaan . Pernyataan untuk apa, dan untuk siapa direncanakan, menunjukkan peranan tujuan dalam perencanaan. Pada setiap pembuatan rencana, perencanaan haruslah sudah mengetahui atau menetapkan tujuannya dan untuk siapakah rencana dibuat. Dalam konteks ini, proses perencanaan diartikan sebagai suatu usaha memaksimumkan segala sumberdaya yang ada pada suatu wilayah atau negara dengan tujuan meningkatkan taraf hidup, kesejahteraan penduduk, dan beban masyarakat yang minimum. Untuk dapat menerapkan asas memaksimumkan segala sumberdaya dengan meminimumkan dana masyarakat, diperlukan kemampuan analisis atas kedua faktor yang bertentangan tersebut.

Dalam perkembangan konsep perencanaan dikemukakan latar belakang munculnya ide tentang perencanaan dalam rangka pembangunan negara. Dikatakan bahwa ilmu perencanaan berkembang selaras dengan perkembangan ilmu ekonomi dan sosial pada abad ke-17. Pelopor bidang perencanaan ini sangat berkaitan dengan pelopor bidang ekonomi seperti Adam Smith, David Ricardo, Keynes dan lain sebagainya.. Perkembangan ilmu perencanaan tidak saja terjadi pada negara-negara yang mengalami Revolusi Industri melainkan juga negaranegara berkembang yang muncul setelah Perang Dunia II, termasuk Indonesia. 
Pada kegiatan belajar 2, Anda diajak untuk memahami tentang arti dan pentingnya perencanaan. Perencanaan yang dimaksud mulai dari yang sederhana (Mikro) hingga perencanaan dalam wawasan Makro. Ada pendapat beberapa ahli yang mengutarakan tentang arti dan pentingnya perencanaan, antara lain $\mathrm{S}$. Prajudi Atmosudirjo, dan Bintoro Tjokroamidjojo. Anda dapat memahami bagaimana alur berpikir jika menjadi seorang perencanaan. Jika ia akan merencanakan suatu program. Apa saja yang harus diperhatikan agar dapat mencapai hasil yang maksimal juga diungkapkan dalam kegiatan belajar ini.

Konsep lain yang dikemukakan dalam modul ini adalah tentang ciri-ciri rencana yang baik. Anda dapat mempelajari sepuluh ciri-ciri dari pendapat Sondang P. Siagian. Batasan-batasan tentang ciri perencana yang baik juga dikemukakan dalam kegiatan belajar 3. Masalah yang terakhir, yang dikemukakan dalam kegiatan belajar 4 adalah tentang bentuk-bentuk Perencanaan. Ada beberapa bentuk perencanaan yang sering digunakan dibanyak negara seperti bentuk yang ditinjau dari segi jangka waktu, segi penggunaan, segi ketat dan tidak ketatnya, segi luas wilayah dan segi keterpaduan

\section{Perkembangan Perencanaan}

Perkembangan sejarah ilmu-ilmu sosial menunjukkan bahwa ilmu ekonomi memiliki peranan tersendiri. Ilmu ekonomi sangat tanggap terhadap berbagai perubahan yang terjadi dalam masyarakat, sehingga dapat dimanfaatkan untuk memecahkan permasalahan yang timbul. Disamping itu, semua orang telah mempelajarinya baik secara sadar ataupun tidak, untuk digunakan dalam memilih alternatif terbaik bagi pemenuhan kebutuhannya dari sumber-sumber yang terbatas. Dalam menentukan altenatif terbaik itu, Hendra Esmara mengemukakan bahwa: "Ilmu ekonomi bergerak kedalam suatu bidang yang biasa disebut Ilmu Ekonomi Politik. Karena itu di dalam ilmu ekonomi politik telah dibahas berbagai kekuatan sosial yang mempengaruhi proses pengambilan keputusan tersebut. Kombinasi ilmu ekonomi dan ilmu politik dalam memecahkan permasalahan 
pembangunan negara sedang berkembang, kemudian dikenal sebagai ilmu ekonomi pembangunan".

Untuk mencapai tingkat pertumbuhan ekonomi yang memadai dengan segala keterbatasan yang dimiliki oleh negara-negara berkembang, maka digunakan ilmu perencanaan ekonomi. Pemikiran tentang perencanaan ekonomi tersebut sebenarnya telah timbul sejak beberapa abad lalu, yang dimulai oleh Adam Smith dengan tulisannya mengenai "An inquiry into the nature and Causes of the Wealth of Nation", tahun 1776. Smith mengemukakan bahwa pertumbuhan ekonomi akan dapat dicapai tanpa pengaturan atau campur tangan pemerintah, karena pengaturannya telah ditangani oleh "invisible hand".

Pendapat Smith ini diperkuat oleh Robert Malthus dan David Ricardo yang pembahasannya lebih ditekankan kepada teori nilai. Bersamaan dengan itu muncul pula teori sosialis yang dikemukakan oleh Karl Mark. Para ahli ini termasuk kedalam aliran klasik. Kemudian terdapat perkembangan analisa tentang analisa pertumbuhan ekonomi yang dikemukakan oleh Marshall. Pembahasannya dilakukan dengan menggunakan peralatan analisa penawaran dan permintaan.

Perkembangan terpenting adalah dengan munculnya pembahasan dari John Mynard Keynes mengenai pertumbuhan ekonomi, yang merupakan pembatas dari konsep dasar sebelumnya. Kalau sebelumnya para ahli ekonomi membahas dari segi nilai dan harga, sedangkan Keynes menelaah ekonomi secara makro yang mengkaitkan perkembangan ekonomi dengan variabel-variabel, seperti tingkat pendapatan, tingkat tabungan, tingkat konsumsi dan tingkat investasi. Keynes juga membahas tentang peranan pemerintah dalam menggunakan peralatan analisa dengan variabel-variabel tersebut seperti keuangan, anggaran belanja negara, neraca pembayaran, dan tingkat harga umum yang dikaji secara rasional. Selain itu Keynes telah mengemukakan konsepnya yang terkenal yaitu sistem pembelanjaan defisit (deficit spendings) dan efek multiplier. 
Setelah Keynes, berkembang pula aliran Neo Keynesian, yang mulai dengan gagasan ekonomi berencana atau adanya campur tangan pemerintah untuk memperbaiki ekonomi dan pertumbuhannya, seperti dikemukakan oleh Walther Rathenau, Sir ray Harrod dan Evsey Domar, Truman dan lain-lain. Gagasan inilah yang menjadi dasar munculnya ilmu perencanaan ekonomi. Dalam perkembangan selanjutnya, ilmu perencanaan ekonomi ini mengalami perubahan mendasar sehingga menjadi ilmu perencanaan pembangunan. Karena kenyataan memperlihatkan bahwa proses pembangunan suatu negara tidak hanya menyangkut masalah ekonomi, tetapi mempunyai hubungan timbal balik yang saling mendukung dengan bidang-bidang lainnya, seperti sosial dan politik.

Meskipun demikian, analisa perencanaan pembangunan masih tetap difokuskan pada perencanaan ekonomi, karena peralatan analisa bidang inilah yang paling maju. Hal ini didukung oleh pengalaman-pengalaman dari beberapa negara, seperti dimulai dengan perencanaan pembangunan di Ghana pada tahun 1919, Rusia pada tahun 1929 dan di India yang merupakan pelopor gagasan perencanaan pembangunan di Asia.

Indonesia mulai pertama kali melakukan perencanaan pembangunan pada tahun 1947 yaitu tentang Rencana dari Panitia Siasat Pembangunan Ekonomi yang diketuai oleh Mohammad Hatta dalam kabinet Syahrir. Pada tahun 1951 telah disusun pula Rencana Urgensi Perekonomian yang mengatur ekonomi dan mengarahkan kegiatan investasi dengan dasar pandangan sosialis. Kemudian pada tahun 1955 Biro Perancang Negara menyusun Rencana Lima Tahun atau dikenal dengan "Rencana Djuanda". Perencanaan itu terus berganti, sejalan dengan keadaan negara pada waktu itu. Kemudian Dewan Perancang Nasional membuat perencanaan yang disebut Pembangunan Nasional Semesta Berencana atau Rencana delapan tahun pada tahun 1961.

Pada masa orde baru pemerintah menyusun perencanaan yang dinamakan Rencana Pembangunan Lima Tahun (Repelita) sebagai hasil perumusan 
Bappenas. Dalam hal ini, Repelita pertama dimulai tahun 1969, sehingga sampai sekarang repelita telah berjalan sebanyak 4 periode.

\section{Hubungan Perencanaan dengan Rencana}

Rencana merupakan hasil nyata dari suatu perencanaan. Seringkali rencana merupakan "blue print" atau cara pencapaiannya. Dalam hal ini, S. Prajudi Atmosudirjo mengemukakan lebih jauh bahwa suatu rencana mengandung unsurunsur sebagai berikut; Tujuan (goal, objective, pemecahan dari suatu masalah, menutup satu demand atau gap). Fakta-fakta (yang harus diperoleh melalui pengumpulan data dan informasi). Perkiraan hari kemudian (forecast, dugaan atau perhitungan hari depan). Serangkaian perbuatan-perbuatan dan aktivitas-aktivitas tertentu (action) yang berhubungan dengan upaya pencapaian tujuan (berdasarkan fakta-fakta dan harapan-harapan).

Berdasarkan uraian-uraian di atas dapat disimpulkan pengertian perencanaan secara umum, yakni meliputi segala kegiatan dan usaha untuk menentukan:

1. Apa yang hendak dicapai

2. Bagaimana cara mencapainya

3. Kapan waktu yang tepat untuk memulainya dan berapa lama waktu yang dibutuhkan, serta

4. Siapa yang akan melaksanakannya yang dijabarkan secara kualitatif dan kuantitatif atas dasar data dan informasi yang tersedia tentang keadaan masa lalu dan masa sekarang dan perkiraan masa datang.

Hal ini menjadi tambah penting terutama bagi mahasiswa yang kuliah disamping bekerja. Mahasiswa itu harus memiliki perencanaan yang matang, baik untuk melakukan kegiatan belajar, bekerja mencari nafkah maupun kegiatan lainnya. Apabila tidak, kemungkinan bisa terjadi kuliahnya mengalami kegagalan atau kondite sebagai karyawan menjadi kurang baik atau gagal kedua-duanya. 
Selanjutnya Bintoro Tjokro Amdjojo, mengemukakan beberapa rumusan tentang perencanaan di dalam bukunya "Perencanaan Pembangunan" yaitu: Perencanaan dalam arti seluas-luasnya tidak lain adalah suatu proses mempersiapkan secara sistematis kegiatan-kegiatan yang akan dilakukan untuk mencapai sesuatu tujuan tertentu. Oleh karena itu pada hakikatnya terdapat pada tiap jenis usaha manusia. Perencanaan adalah penentuan tujuan yang akan dicapai atau yang akan dilakukan, bagaimana, bilamana dan oleh siapa. Albert Waterson menyebutkan perencanaan pembangunan adalah "melihat ke depan" dengan mengambil pilihan berbagai alternatif dari kegiatan untuk mencapai tujuan masa depan tersebut dengan terus mengikuti agar supaya pelaksanaannya tidak menyimpang dari tujuan. Perencanaan pembangunan adalah suatu pengarahan penggunaan sumber- sumber pembangunan (termasuk sumbersumber ekonomi) yang terbatas adanya, untuk mencapai tujuan-tujuan keadaan sosial ekonomi yang lebih baik secara lebih efisien dan efektif.

Pengertian perencanaan ini juga dikemukakan oleh Widjojo Nitisastro dalam pidato pengukuhannya sebagai guru besar pada Fakultas Ekonomi Universitas Indonesia;

Perencanaan pada asasnya berkisar pada dua hal yaitu (1) Perencanaan berhubungan dengan penentuan pilihan secara sadar mengenai tujuan-tujuan konkrit yang hendak dicapai dalam waktu tertentu atas dasar nilai-nilai yang dimiliki masyarakat yang bersangkutan. (2) Perencanaan berkaitan dengan pilihan diantara cara-cara alternatif yang efisien serta rasional guna mencapai tujuantujuan tersebut. Baik untuk penentuan tujuan yang meliputi jangka waktu tertentu maupun bagi pemihan cara-cara tersebut diperlukan ukuran-ukuran atau kriteria-kriteria tertentu yang terlebih dahulu harus dipilih pula.

Menurut SPPN 25 tahun 2014 menyatakan bahwa Perencanaan adalah suatu proses untuk menentukan tindakan masa depan yang tepat, melalui urutan pilihan, dengan memperhitungkan sumber daya yang tersedia. Dengan demikian, apabila 
pengertian perencanaan itu dikaji lebih mendalam, maka akan dapat diketahui bahwa pada dasarnya suatu perencanaan itu meliputi berbagai kegiatan, seperti:

\section{Berpikir}

Seorang perencana harus merumuskan kegiatan-kegiatan dan usaha-usaha sebelum hal tersebut dilaksanakan. Artinya, perencana harus bisa membayangkan secara konsepsualisasi tentang berbagai kegiatan dan usaha yang akan dilakukan dan menelaah setiap kegiatan serta mencarikan jalan keluar bagi setiap hambatan yang mungkin timbul.

2. Pengambilan keputusan sekarang

Keputusan itu diambil pada masa sekarang atas dasar pengalaman masa lalu dan keadaan sekarang untuk dilaksanakan pada masa yang akan datang. Kegiatan ini meliputi pengumpulan dan pengkajian seluruh data dan informasi yang berkaitan, sehingga bisa diambil keputusan.

3. Pembentukan dasar-dasar yang rasional

Mengingat perumusan suatu perencanaan didasarkan kepada pengalaman masa lalu dan keadaan sekarang, yang betul-betul telah terjadi, maka diharapkan perkiraan untuk masa datang minimal akan mendekati keadaan yang sebenarnya. Atau dengan perkataan lain, perencanaan itu telah disusun menurut pengalaman dan fakta yang dapat dipertanggungjawabkan, sehingga menghasilkan suatu dasar- dasar yang rasional. Dengan demikian, hal itu akan memudahkan bagi penentuan berbagai kegiatan dan usaha apa yang diperlukan untuk mengendalikan atau menghadapi setiap permasalahan yang timbul akibat suatu perubahan, terutama perubahan yang terjadi di luar dugaan.

4. Pemilihan data dan informasi yang diperlukan untuk peramalan Sebagaimana diketahui, data dan informasi mengenai masa lalu dan masa sekarang yang tersedia sangat banyak ragamnya. Untuk itu diperlukan kegiatan untuk melakukan pemilihan terhadap data dan informasi yang berkaitan dengan tujuan perencanaan yang telah ditetapkan. 
5. Persiapan yang sistematis

Hal ini disebut juga sebagai arti lain dari perencanaan. Karena pada perencanaan ini sendiri telah disusun sedemikian rupa tahapan-tahapan dari kegiatan dan usaha yang akan dilakukan dalam mencapai suatu tujuan.

6. Pengalokasian sarana dan prasarana yang terbatas

Jumlah dan keadaan sarana dan atau prasarana yang tersedia belum tentu mencukupi kebutuhan dari pelaksanaan suatu perencanaan. Untuk itu perlu dialokasikan sehingga dapat diketahui dan dikaji keadaan fasilitas itu, agar bisa dimanfaatkan secara maksimal guna mendukung pelaksaannya.

7. Penentuan metode dan teknik

Hal ini sangat penting, karena setiap metode dan teknik memiliki kelemahan-kelemahan dan kelebihan-kelebihan masing-masingnya. Disamping itu, metode dan teknik tersebut belum tentu dapat dilaksanakannya dengan baik, mengingat keterbatasan yang dimiliki dan lingkungan yang tidak sesuai.

Jelaslah sekarang bahwa untuk mencapai hasil yang optimal diperlukan suatu perencanaan yang baik. Pentingnya perencanaan ini adalah karena; Merupakan alat yang efisien dan efektif untuk mencapai tujuan yang diinginkan. Dengan demikian, pemborosan yang mungkin terjadi, seperti pemborosan dana dan daya akan dapat dihindari karena berapa besarnya dana dan daya yang diperlukan untuk berbagai kegiatan dan usaha tersebut dapat terlihat jelas dalam suatu rencana. Memberikan kesempatan untuk memilih berbagai alternatif tentang cara yang diperkirakan sebagai cara yang terbaik. Karena caracara tersebut telah dikaji sedemikian rupa, baik mengenai ciri-ciri setiap alternatif maupun kebaikan atau kelemahan yang dimiliki masing-masingnya. Merupakan dasar utama yang rasional untuk penjabaran lebih lanjut dalam pelaksanaan. Memberikan gambaran yang jelas tentang jenis dan bentuk satuan kerja serta jumlah tenaga yang diperlukan untuk menyelenggarakannya. Terutama mengenai kebutuhan 
yang tepat dalam hal jumlah, jenis keahlian dan keterampilan tenaga kerja disamping kebutuhan akan sarana dan prasarana kerja yang mutlak harus tersedia. Dapat mengurangi ketidakpastian yang akan dihadapi di masa datang. Karena suatu perencanaan yang matang telah memperkirakan keadaan yang akan terjadi dan prospek yang dapat dicapai. Merupakan standard yang menjadi tolok ukur bagi penentuan keberhasilan berbagai kegiatan dan usaha yang dilakukan. Dengan adanya tolok ukur itu, maka setiap kegiatan dan usaha akan dapat dinilai dan diawasi bahkan dikendalikan agar tujuannya dapat dicapai secara efektif dan efisien.

\section{Ciri-Ciri Rencana Yang Baik}

Perlu disadari bahwa betapapun suatu rencana telah disusun dengan baik dan sistematis, belum berarti hal tersebut akan dapat menjamin hasilnya yang sempurna. Dalam hal ini, Sondang P. Siagian mengemukakan bahwa, perlu diusahakan agar suatu rencana memiliki ciri-ciri tertentu seperti:

Pertama, suatu rencana harus mempermudah seluruh usaha untuk mencapai tujuan. Oleh karenanya, harus jelas dipahami oleh pihak-pihak yang terlibat dalam penyusunan rencana bahwa rencana bukanlah tujuan. Rencana hanyalah sekadar alat yang merupakan hasil kegiatan yang bersifat mental konseptual, yang baik tidaknya hanya akan terlihat dalam pelaksanaan.

Kedua, penyusunan rencana tidak bisa diserahkan kepada sekelompok orang yang kedalaman persepsi dan pengetahuannya tentang hakiki daripada tujuan yang hendak dicapai masih diragukan. Jika hal demikian sampai terjadi, tidak mustahil rencana yang disusun akan hanya didasarkan kepada pendekatan teoritikal belaka tanpa relevansinya dengan tujuan yang menjadi sasaran akhir seluruh kegiatan yang akan dilaksanakan.

Ketiga, para penyusun rencana hanya harus terdiri daripada tenaga profesional disamping ahli dan terampil dalam penggunaan berbagai teknik perencanaan, juga telah memiliki pengalaman praktek di lapangan. Betapapun 
pentingnya pengetahuan teoritikal, profesionalisme dalam perencanaan membutuhkan pula pengalaman operasional sehingga terdapat perpaduan antara teori dan "dunia kenyataan”. Dengan demikian pimpinan organisasi, yang pada analisa terakhir memang bertanggung jawab atas rencana yang terdapat dalam organisasinya, tidak lagi dibebani dengan tugas untuk melakukan analisa mendetail terhadap berbagai alternatif yang diajukan oleh stafnya.

Keempat, pada umumnya, betapapun matangnya suatu rencana disusun, ia tetap hanya mengandung hal-hal yang masih bersifat umum dan perlu dijabarkan ke dalam proses kerja. Oleh karena itu dalam rencana yang baik harus terdapat petunjuk yang jelas tentang substansi dan teknik penjabaran yang memang harus dilakukan sebelum dilaksanakan.

Kelima, rencana yang baik tidak boleh terlepas dari pemikiran pelaksanaan. Dengan perkataan lain, tidak boleh terjadi adanya polarisasi antara rencana disatu pihak dan pelaksanaan di pihak lain.

Keenam, kesederhanaan bentuk dan isi, merupakan ciri penting dari suatu rencana yang baik. Yang dimaksud dengan kesederhanaan disini pada hakikatnya adalah bahwa suatu rencana yang baik menggambarkan secara jelas skala prioritas yang logis, mudah dipahami oleh mereka yang akan terlibat dalam pelaksanaan rencana, meskipun mereka tidak turut berperan dalam penyusunan rencana dan mudah dijabarkan oleh para pelaksana tanpa tuntutan profesionalisme yang tinggi dalam bidang perencanaan.

Ketujuh, keluwesan sebagai ciri suatu rencana yang baik. Kelakuan dalam rencana dapat berakibat kesukaran dalam melakukan penyesuaian-penyesuaian yang pasti harus dilakukan. Pengalaman menunjukkan bahwa keluwesan itu sangat diperlukan karena tuntutan kondisi yang biasanya berubah dengan pengertian bahwa dalam melakukan penyesuaian yang diperlukan, pola dasar rencana sebagai keseluruhan tidak seharusnya sering diubah. Seperti telah diuraikan dimuka, perencanaan adalah proses yang berjalan terus menerus. Tugas 
merencanakan tidak pernah berakhir. Kondisi memang pasti akan berubah. Sasaransasaran dapat timbul. Teknik metoda kerja baru diciptakan. Kesemuanya itu akan menuntut adanya penyesuaian dalam rencana. Dengan perkataan lain, meskipun suatu rencana telah ditetapkan, penetapan itu tidak seharusnya bersifat "harga mati" yang tidak bisa ditawar-tawar lagi. Dalam pada itu, memang diperlukan pula kwaspadaan jangan sampai suatu rencana menjadi sedemikian luwesnya sehingga mengalami perubahan yang sering terjadi tanpa alasan yang cukup kuat. Perubahan yang sering terjadi terhadap suatu rencana akan dapat menimbulkan kebingungan para pelaksana, yang apabila terjadi bukan saja akan berakibat pada berbagai macam pemborosan, akan tetapi juga menjadi penghalang terhadap pencapaian tujuan.

Kedelapan, adanya ruang pengambilan resiko yang telah diperhitungkan sebelumya. Betapapun besarnya sumbangan ilmu pengetahuan dan teknologi dalam meningkatkan kemampuan manusia untuk memperkirakan keadaan dimasa depan, kiranya masih tidak dapat dipungkiri apabila dikatakan bahwa tidak ada seorang manusia pun yang tahu persis apa yang akan terjadi di masa mendatang. Karena orientasi suatu rencana memang adalah masa depan, maka diperlukan ruang untuk pengambilan resiko atas dasar perhitungan yang secermat mungkin sehingga faktor ketidakpastian paling sedikit tidak akan mengakibatkan terjadinya pendadakan dengan kegoncangan yang membahayakan pelaksanaan rencana.

Kesembilan, pragmatisme sebagai ciri rencana. Artinya, dalam perencanaan, pendekatan "menara gading" harus dihindari dengan memperhitungkan tujuan yang hendak dicapai, kemampuan riil dan potensial yang terdapat dalam organisasi, faktor-faktor lingkungan yang turut berpengaruh, kesempatan yang diperkirakan akan tersedia dimasa depan serta dampak faktor ketidakpastian yang harus diperhitungkan sejauh mungkin. 
Kesepuluh, aktualitas sebagai ciri rencana. Yang dimaksud dengan aktualitas adalah penggabungan yang operasional antara teori dan praktek di lapangan karena yang disusun secara ilmiah hanya ada manfaatnya apabila dapat dilaksanakan dalam keadaan nyata di lapangan, dalam rangka pencapaian tujuan yang telah ditetapkan sebelumnya.

Berpedoman kepada uraian di atas, ciri-ciri rencana yang baik itu dapat lebih disederhanakan menjadi seperti berikut:

1. Rencana harus memberi kemudahan dalam melaksanakan kegiatan dan usaha pencapaian tujuan. Untuk itu suatu rencana harus jelas dan dapat dipahami oleh setiap pihak yang terlibat didalamnya serta bisa dilaksanakan di lapangan guna mencapai tujuan yang telah ditetapkan sebelumnya.

2. Rencana harus dirumuskan oleh tenaga ahli yang kuat dalam teori dan memiliki pengalaman yang mendukung di bidang operasional serta mendalami hakiki dari tujuan yang hendak dicapai. Tujuannya adalah terdapat keterpaduan antara teori dan praktek serta motivasi yang baik dari para perencana untuk menghasilkan suatu rencana yang rasional, aktual dan pragmatis atas dasar data dan kebutuhan yang sebenarnya.

3. Rencana yang memiliki fleksibilitas yang dapat disesuaikan dengan setiap perubahan yang terjadi. Namun pola dasar dari rencana harus mantap.

4. Rencana harus memiliki bentuk dan isi yang sederhana sehingga dapat dijabarkan ke dalam program kerja dengan skala prioritas yang wajar. Dengan demikian tidak terjadi suatu polarisasi antara rencana an sich di satu pihak dan pelaksanaannya di lain pihak.

5. Rencana harus memiliki batas toleransi yang menjadi dasar dalam mengevaluasi setiap penyimpangan yang terjadi. Hal ini bermanfaat untuk menampung kejadian-kejadian masa mendatang yang belum pasti, sehingga setiap terjadi penyimpangan, hal tersebut tidak akan menimbulkan goncangan yang dapat mengganggu atau menghambat pelaksanaan. Karena 
setiap penyimpangan yang masih dalam batas toleransi telah diperhitungkan sebelumnya.

\section{E. Bentuk-Bentuk Perencanaan}

Pada dasarnya bentuk-bentuk perencanaan banyak sekali. Hal itu tergantung dari segi mana kita hendak mengklasifikasikannya. Dalam pembahasan disini, bentuk-bentuk perencanaan dibatasi khusus beberapa segi yang berkaitan dengan perencanaan pembangunan, yaitu:

1. Segi jangka waktu.

Perencanaan dari segi ini biasanya dibedakan atas perencanaan jangka panjang, jangka menengah dan jangka pendek. Perencanaan jangka panjang dikenal juga sebagai perencanaan perspektif yang menggambarkan tujuan dan sasaran yang luas dimana harus dicapai dalam jangka panjang, sedangkan perencanaan jangka menengah dan jangka pendek merupakan perencanaanperencanaan yang menunjangnya. Berarti perencanaan jangka panjang bukanlah suatu perencanaan untuk keseluruhan jangka waktu itu, tetapi tujuan dan sasarannya itu dibagi kedalam perencanaan jangka menengah yang diteruskan lagi ke dalam perencanaan jangka pendek. Biasanya jangka waktu perencanaan jangka panjang adalah 10, 20 atau 30 tahun, jangka menengah lebih dari 1 tahun dan jangka pendek maksimal 1 tahun.

Tujuan pokok perumusan rencana jangka panjang adalah untuk meletakkan dasar bagi rencana-rencana jangka menengah dan jangka pendek, sehingga tujuan dan sasaran jangka panjang itu dapat dicapai secara bertahap sesuai dengan kurun waktu dari masing-masing rencana jangka menengah dan jangka pendek. Hal tersebut diperkuat lagi dengan hasil pengamatan P. C. Mahalanobis, yaitu Rencana perspektif memerlukan proses berkesinambungan yang mempunyai dua aspek. Pertama, rencana yang sedang berjalan diarahkan pada proyek-proyek yang dicantumkan dalam rencana tahunan di dalam kerangka Rencana Lima Tahun. Kedua, rencana- 
rencana lima tahun itu sendiri harus disesuaikan dengan kerangka perencanaan perspektif yang lebih luas dengan tenggang waktu yang panjang 10, 10, 30 tahun atau lebih".

2. Segi penggunaan

Dalam hal ini, suatu perencanaan dibedakan atas perencanaan tetap dan perencanaan beruntun.

a. Perencanaan tetap (fixed planning)

Pemakaian istilah "tetap" disini adalah tujuan yang akan dicapai tetap selama kurun waktu rencana, baik fisik maupun pembiayaan keseluruhan. Tujuan itu baru dapat diubah apabila terdapat keadaan darurat. Perencanaan ini memiliki beberapa kebaikan yaitu Tujuan dan prioritas pembangunannya tetap, dalam hal mana harus ditentukan secara tegas dan pasti dalam rencana, yang mencakup semua aspek untuk bisa dipenuhi oleh pemerintah, swasta dan masyarakat selama kurun waktu rencana yang ditetapkan. Terdapat keseimbangan yang relatif tetap dalam perekonomian, karena rencana telah ditetapkan untuk suatu kurun waktu yang pasti sehingga langkah kebijakan moneter, fiskal dan kebijakan lainnya bisa dilakukan lebih dini guna menjaga keseimbangan itu.Terdapat peningkatan kerja sama yang kuat antara masyarakat dan kemauan politik pemerintah, karena mereka tahu dan sadar akan kepentingannya.

b. Perencanaan beruntun (rolled planning)

Bentuk perencanaan ini merupakan suatu proses yang berkesinambungan yang mana setiap tahun rencana yang telah ditetapkan sebelumnya diperbaiki atas dasar data dan informasi terakhir serta teknik analisa yang lebih baik. Biasanya terdapat tiga rencana baru yang dirumuskan dan dilaksanakan setiap tahun, yang merupakan revisi dari rencana-rencana sebelumnya. Rencana jangka pendek dibuat dan disesuaikan dengan 
rencana jangka menengah yang baru dari tahun yang sama, dan keduanya disusun sesuai dengan rencana jangka panjang.

3. Segi ketat atau kurang ketatnya

Bentuk perencanaan yang ketat ini disebut juga perencanaan komando (planning by direction), yang merupakan bagian integrasi dari masyarakat sosialis. Pemerintah pusat merumuskan perencanaan yang menyeluruh, mengatur dan memerintahkan pelaksanaannya untuk mewujudkan tujuan yang ditetapkan. Sekali suatu rencana yang ditetapkan berarti tidak terdapat kemungkinan untuk mengubahnya. Biaya untuk suatu perubahan rencana sangat mahal, karena satu bagian saja yang diperbaiki berarti harus memperbaiki keseluruhannya. Atau dengan perkataan lain, perencanaan ini akan menimbulkan pemaksaan. Masyarakat tidak memiliki kebebasan untuk memilih barang-barang yang akan dikonsumsi ataupun memilih lapangan pekerjaan yang disenangi, sehingga bisa dihasilkan suatu keseimbangan material antara jumlah persediaan dan jumlah permintaan untuk setiap komoditi.

Sementara itu, perencanaan yang kurang ketat dikenal sebagai perencanaan dengan rangsangan (planning by inducement), yang merupakan perencanaan demokratis melalui manipulasi pasar. Dalam hal ini, masyarakat memiliki kebebasan baik untuk berusaha, mengkonsumsi, berproduksi ataupun untuk memilih pekerjaan yang disenangi. Namun kebebasan itu harus terkendali sesuai dengan pengaturan pemerintah, dimana kebijakan pemerintah itu hanya bersifat mendorong dan mengajak, sehingga tujuannya dapat dicapai. Pemerintah disini hanya mengambil langkah-langkah yang tepat untuk menjaga agar permintaan agregat tidak terlalu kecil atau besar sehingga terhindar dari resesi sector masyarakat.

4. Segi luasnya wilayah 
Berdasarkan luasnya wilayah, suatu perencanaan biasanya dikategorikan atas perencanaan nasional, perencanaan regional dan perencanaan local.

\section{a. Perencanaan Nasional}

Perencanaan ini umumnya merumuskan hal-hal yang mencakup wilayah atau negara dengan mempertimbangkan potensi yang tersedia, kondisi dan struktur baik di bidang ekonomi, sosial maupun politik. Perencanaan ini bisa bersifat sentralisasi atau disentralisasi. Di dalam perencanaan sentralisasi, semua proses perencanaan suatu negara dilaksanakan oleh badan perencanaan pusat. Sebaliknya perencanaan desentralisasi mengacu kepada perencanaan yang disusun oleh badan perncanaan pusat setelah mendapat masukan dari berbagai instansi pemerintah lainnya ditingkat pusat dan daerah.

b. Perencanaan Regional

Dalam hal ini, perencanaan regional merupakan suatu perencanaan yang mencakup satu daerah, yang seringkali merupakan bagian terpadu dari perencanaan nasional. Perencanaan ini meliputi berbagai kegiatan dan usaha baik dari pemerintah pusat maupun pemerintah daerah yang ditujukan bagi peningkatan taraf hidup masyarakat di daerah yang bersangkutan.

c. Perencanaan lokal

Bentuk perencanaan ini tidak berbeda jauh dengan perencanaan regional namun dalam luas wilayah yang lebih kecil. Perncanaan yang dirumuskan meliputi berbagai kegiatan dan usaha dari pemerintah pusat, pemerintah daerah dengan peringkat yang lebih tinggi dan pemerintah daerah (lokal) denga peringkat yang lebih rendah itu sendiri.

5. Segi keterpaduan 
Perencanaan dari segi ini diklasifikasikan atas perencanaan komprehensif, perencanaan sektoral dan perencanaan proyek.Perencanaan komprehensif atau inflasi dan mencegah terjadinya monopoli serta memenuhi kebutuhan. Biasanya perencanaan komprehensif ini disebut juga sebagai perencanaan lintas sektoral. Karena perencanaan itu merumuskan semua kegiatan dan usaha yang meliputi sektor pemerintah dan sektor masyarakat serta mengkaitkan kebijakan antara sektor-sektor tersebut. Perencanaan komprehensif juga bersifat menyeluruh dan terpadu yang meliputi berbagai bidang kehidupan masyarakat, seperti ekonomi, sosial dan politik. Perencanaan Sektoral. Perumusan suatu perencanaan sektoral biasanya meliputi berbagai kegiatan dan usaha yang berupa kebijakan program untuk pembangunan di suatu sector tertentu. Perumusan disini haruslah terkait dengan perencanaan komprehensif sehingga pertentangan yang timbul antara beberapa sektor dapat dihindari. Perencanaan Proyek. Suatu perencanaan proyek umumnya mencakup berbagai kegiatan dan usaha untuk melaksanakan proyek pembangunan pada sector-sektor tertentu. Perencanaan proyek ini tidak bisa lepas dari perencanaan sektoral dan perencanaan komprehensif dalam rangka mencapai cita-cita pembangunan nasional.

\section{F. Unsur-Unsur Perencanaan}

Menurut Harol koonth \& co donnel mengemukakan bahwa suatu perencanaan harus mengandung unsur-unsur sebagai berikut:

a. Tujuan

Yaitu segala sesuatu yang hendak dicapai dalam usaha kerjasama atau organisasi. Tujuan yang dimaksudkan dapat berupa material ataupun alat pemuas kebutuhan spiritual. Untuk dapat dipakai sebagai dasar dalam pelaksanaan kerja, maka tujuan yang hendak dicapai haruslah dirumuskan secara jelas dan tegas.

b. Politik atau kebijaksanaan 
Adalah merupakan peraturan-peraturan atau pedoman yang digariskan oleh organisasi. Atau dengan kata lain lazim disebut sebagai pedoman tindakan untuk mencapai tujuan.

c. Prosedur

Yaitu suatu tata urutan pelaksanaan kerja yang harus dilakukan atau diikuti. Jadi dengan prosedur orang-orang akan senantiasa mengetahui dari mana mereka harus memulai dan mengakhiri tugas-tugasnya.

\section{d. Budget}

Yaitu suatu anggaran yang berupa ikhtisar daripada hasil yang diharapkan akan dicapai dan beaya atau input yang diperlukan untuk mencapai hasil itu. Budget itu lazimnya dinyatakan dalam bentuk angka-angka.

e. Program

Adalah campuran dari pada tujuan, politik, prosedur, dan budget yang dimaksudkan untuk menetapkan suatu kerangka tindakan untuk waktu yang akan datang.

Sujarto (1990) menyebutkan terdapat unsur-unsur pokok yang terkandung dalam perencanaan, yaitu:

1. Unsur keinginan atau cita-cita;

2. Unsur tujuan dan motivasi;

3. Unsur sumber daya alam, manusia, modal dan informasi;

4. Unsur upaya hasil guna dan dayaguna;

5. Unsur ruang dan waktu.

Sedangkan menurut kunarjo (2002) pada dasarnya secara umum perencanaan didefinisikan sebagai suatu proses penyiapan seperangkat keputusan untuk dilaksanakan pada waktu yang akan datang yang diarahkan pada pencapaian sasaran tertentu. Dengan definisi tersebut maka perencanaan mempunyai unsurunsur: 
1. Berhubungan dengan hari depan,

2. Mendesain seperangkat kegiatan secara sistematis,

3. Dirancang untuk mencapai tujuan tertentu.

Jadi dapat disimpulkan bahwa unsur-unsur sangat perlu diperhatikan dalam perencanaan karena dalam mengatur sebuah rencana perlu dirumuskannya tujuan yang akan di capai dan harus terpenuhinya semua unsur-unsur yang mendukung dalam perencanaan, karena perencanaan pada prinsipnya merupakan kegiatan yang berorientasi pada masa depan, atau dengan perkataan lain perencanaan merupakan seperangkat kegiatan yang dilakukan sebelum kegiatan tersebut terjadi.

Jika dilihat dari prakteknya dilapangan dalamberbagai perencanaan seperti dalam RPJP (Rencana Pembangunan Jangka Panjang) dan RPJM (Rencana Pembangunan Jangka Menangah), unsur-unsur perencanaan sebagai berikut :

1. Visi (vision): suatu kondisi ideal (cita-cita) normatif yang ingin di capai di masa datang.

2. Misi (mission): cara normatif untuk mencapai visi.

3. Tujuan-tujuan (goals): hal-hal yang ingin dicapai secara umum. Setiap bentuk tujuan (goal) bersifat dapat dimaksimumkan atau diminimumkan.

4. Sasaran (objective): bentuk operasional dari tujuan, biasanya lebih terukur, disertai target pencapaiannya. Kondisi minimum yang harus dicapai dalam mencapai tujuan dalam waktu tertentu.

5. Strategi (strategy): sekumpulan sasaran dengan metode-metode untuk mencapainya.

6. Kebijakan (policy): sekumpulan aktivitas (actions), untuk pelaksanaan- pelaksanaan pencapaian jangka pendek.

7. Aktivitas (actions): kegiatan pelaksanaan, khususnya menyangkut 
fisik dan biaya.

8. Program (program): sekumpulan aktivitas (actions) untuk mencapai suatu tujuan tertentu yang dilakukan oleh suatu institusi tertentu.

9. Proyek (project): sekumpulan aktivitas (actions) untuk mencapai suatu tujuan/target/sasaran tertentu yang dilakukan oleh suatu institusi tertentu dalam waktu tertentu dengan sumberdaya (biaya) tertentu.

Mengacu pada unsur utama dalam perencanaan, visi, tujuan, dan sasaran istilah yang menjelaskan mengenai unsur perencanaan yang pertama (hal yang ingin dicapai); sedangkan misi dan aktivitas adalah istilah- istilah mengenai unsur perencanaan yang kedua (cara untuk mencapai). Kemudian strategi, program dan proyek merupakan suatu set kumpulan komponen perencanaan hingga pelaksanaannya (mencakup dua unsur perencanaan) dalam suatu struktur tertentu (rustiadi, e. Et al. 2009).

Untuk itu berdasarkan berbagai definisi perencanaan, setidaknya ada 4 unsur dasar dalam perencanaan, yakni (conyer \& hill, 1984):

1. Merencanakan berarti memilih

2. Perencanaan sebagai alat untuk mengalokasikan sumberdaya

3. Perencanaan sebagai alat untuk mencapai tujuan

4. Perencanaan adalah untuk masa datang.

Uraian keempat unsur dasar perencanaan tersebut adalah sebagai berikut:

1. Merencanakan berarti memilih; artinya, perencanaan merupakan proses memilih di antara berbagai kegiatan yang diinginkan, karena tidak semua yang diinginkan itu dapat dilakukan dan dicapai dalam waktu yang bersamaan. Hal itu menyiratkan pengertian bahwa hubungan antara perencanaan dan proses pengambilan keputusan sangat erat. Oleh karena itu, banyak buku mengenai perencanaan membahas pendekatan alternatif dalam proses pengambilan 
keputusan, terutama berkaitan dengan faktor- faktor yang mempengaruhi pengambilan keputusan dan urutan tindakan di dalam proses pengambilan keputusan.

2. Perencanaan merupakan alat pengalokasian sumber daya. Penggunaan istilah sumber daya menunjukkan segala sesuatu yang dianggap berguna dalam pencapaian suatu tujuan tertentu. Sumber daya mencakup sumber daya manusia; sumber daya alam (tanah, air, hasil tambang, dan sebagainya); sumber daya buatan. Perencanaan mencakup proses pengambilan keputusan tentang bagaimana sumber daya yang tersedia itu digunakan sebaik-baiknya. Oleh karena itu, kuantitas dan kualitas sumber daya tersebut sangat berpengaruh dalam proses memilih di antara berbagai pilihan tindakan yang ada.

3. Perencanaan merupakan alat untuk mencapai tujuan. Konsep perencanaan sebagai alat pencapaian tujuan muncul berkenaan dengan sifat dan proses penetapan tujuan. Salah satu masalah yang sering dihadapi oleh seorang perencana adalah bahwa tujuan-tujuan mereka kurang dapat dirumuskan secara tepat. Sering kali tujuan-tujuan tersebut didefinisikan secara kurang tegas, karena kadang kala tujuan-tujuan tersebut ditetapkan oleh pihak lain.

4. Perencanaan mengacu ke masa depan. Salah satu unsur penting dalam perencanaan adalah unsur waktu. Tujuan perencanaan dirancang untuk dicapai pada masa yang akan datang. Oleh karena itu, perencanaan berkaitan dengan antisipasi ke masa depan, bukan semata-mata menjawab persoalan-persoalan masa kini.

Dari pengertian perencanaan di atas bersifat umum yang dapat diterapkan baik dalam konteks kepentingan privat maupun publik. Perencanaan wilayah dan kota pada dasarnya berkaitan dengan publik domain. Oleh sebab itu, pengertian perencanaan yang dimaksud mempunyai karakteristik (alexander, 1986): 
1. Bukan aktivitas individual;

2. Bukan berorientasi pada masa kini;

3. Bukan kegiatan rutin;

4. Bukan trial and error dalam pemecahan masalah;

5. Bukan sekedar membayangkan masa depan yang diinginkan/utopian; dan

6. Tidak terbatas pada pembuatan rencana, tapi terkait dengan tindakan (pelaksanaan).

Jadi perencanaan pada dasarnya bukan kegiatan individual, tetapi dilakukan dalam konteks masyarakat (society). Dalam hal ini jelas terdapat banyak kepentingan yang harus diakomodasi. Untuk itu diperlukan unsur-unsur yang mendukung agar tujuan yang hendak dicapai sesuai dengan perencaan yang telah dibuat.

Perencanaan juga tidak berorientasi pada masa kini tapi pada masa depan, oleh karena itu perencanaan tidak sekedar memberikan solusi pada masalah-masalah yang ada sekarang ini. Perencanaan harus dapat mengantisipasi berbagai masalah yang muncul di masa yang akan datang dan berupaya untuk memberikan alternatif solusinya.

\section{G. Hubungan Perencanaan dan Pembangunan}

Dua landasan hukum yang menjadi dasar untuk penyusunan perencanaan pembangunan pusat dan daerah adala undang-undang no.25 tahun 2004 tentang sistem perencanaan pembangunan nasional (sppn) dan undang-undang no.23 tahun 214 tentang pemerintahan daerah.

Undang-undang no. 25 tahun 2004 tentang sppn bab ii pasal 2 menjelaskan mengenai tujuan sppn adala untuk menjamin terciptanya integrase, sinkronisasi, dan sinergi baik antar daerah, antarruang, antarwaktu, antarfungsi pemerintah 
maupun antara pusat dan daerah. Ditegaskan kemudian pada pasal 5 yang berbunyi bahwa rpjmd harus memperhatikan rpjp daerah dan rpjmn.

Sedangkan undang-undang no.23 tahun 2014 tentang pemerintah daerah pada bagian kedua mengenai perencanaan pembangunan daerah di pasal 263 menyatakan bahwa penyusunan rpjmd harus berpedoman pada rpjpd dan rpjmn. Disusul pasal 264 menyatakan tentang rpjmd dapat disesuaikan dengan terhadap kebijakan yang ditetapkan oleh pemerintah pusat. Selanjutnya pasal 269 dan pasal 271 berbunyi tentang proses evaluasi rpjmd provinsi dan rpjmd kabupaten/kota yang dapat dilakukan uji kesesuaian dengan rpjmn atau rpjmd provinsi untuk kabupaten.

Melalui bahasan di atas, terlihat bahwa rpjmn dan rpjmd adalah dua hal yang saling berhubungan dan harus sinkron satau sama lain. Berikut gambaran mengenai proses perencanaan pembangunan pusat dan daerah:

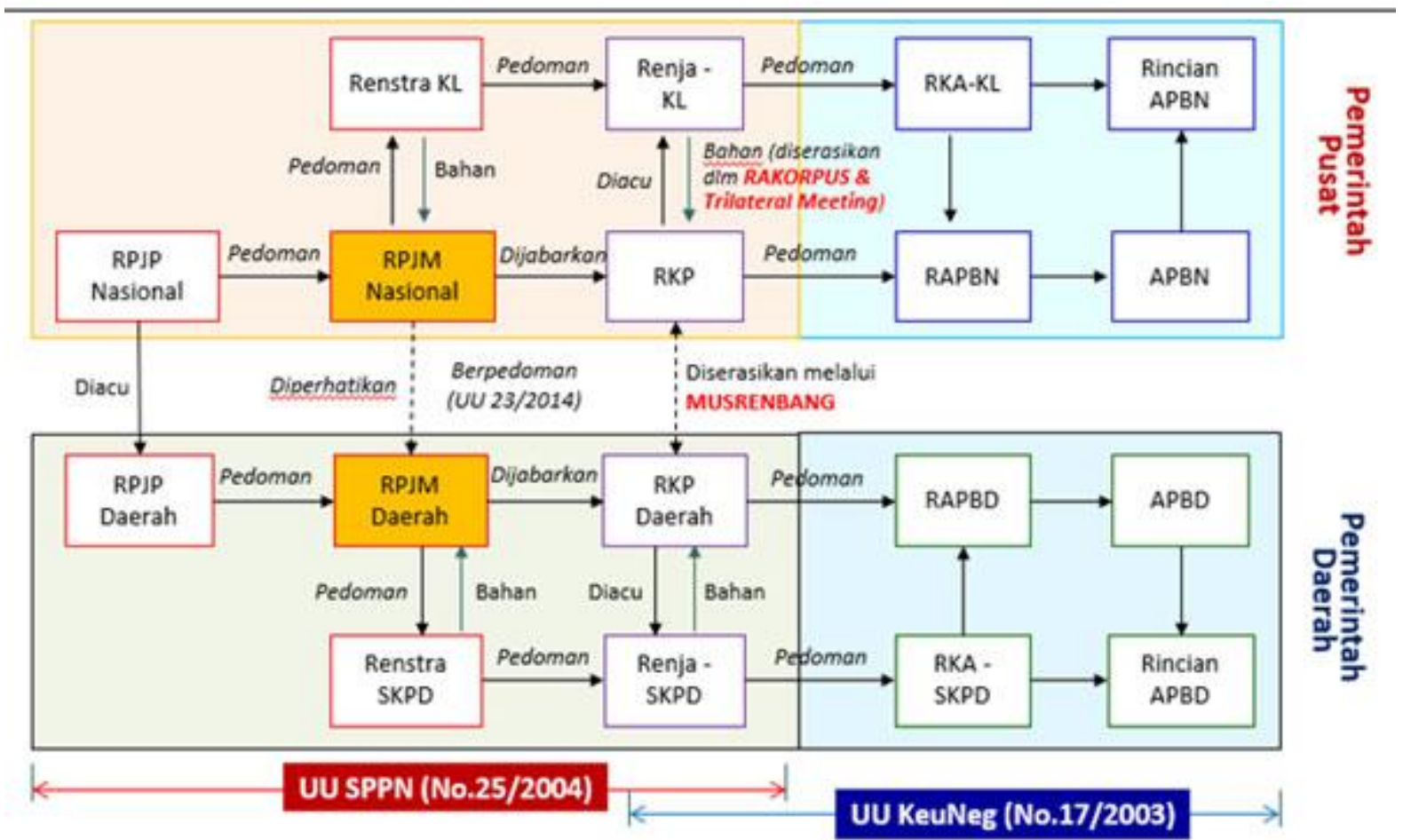


Gambar 2. Skema rencana pembangunan pusat dan daerah

Rpjm nasional merupakan penjabaran dari visi, misi, dan program presiden yang penyusunannya berpedoman pada rpjp nasional, yang memuat strategi pembangunan nasional, kebijakan umum, program kementerian/lembaga dan lintas kementerian/lembaga, kewilayahan dan lintas kewilayahan, serta kerangka ekonomi makro yang mencakup gambaran perekonomian secara menyeluruh termasuk arah kebijakan fiskal dalam rencana kerja yang berupa kerangka regulasi dan kerangka pendanaan yang bersifat indikatif.

RPJM adalah dokumen perencanaan daerah untuk periode 5 (lima) tahun. Rencana pembangunan tahunan daerah yang selanjutnya disebut rencana kerja pemerintah daerah yang selanjutnya disingkat rkpd adalah dokumen perencanaan daerah untuk periode 1 (satu) tahun. Pasal 263 ayat 2 uu no. 23 tahun 2014 rpjpd sebagaimana dimaksud pada ayat (1) huruf a merupakan penjabaran dari visi, misi, arah kebijakan, dan sasaran pokok pembangunan daerah jangka panjang untuk 20 (dua puluh) tahun yang disusun dengan berpedoman pada rpjpn dan rencana tata ruang wilayah. Pasal 263 ayat 3 uu no. 23 tahun 2014 rpjmd merupakan penjabaran dari visi, misi, dan program kepala daerah yang memuat tujuan, sasaran, strategi, arah kebijakan, pembangunan daerah dan keuangan daerah, serta program perangkat daerah dan lintas perangkat daerah yang disertai dengan kerangka pendanaan bersifat indikatif untuk jangka waktu 5 (lima) tahun yang disusun dengan berpedoman pada RPJP dan RPJM.

Misalnya tahun 2015, indonesia memasuki tahap ketiga dalam rencana menengahnya yang tertuang dalam rpjmn 2015-2019. Bertepatan dengan ini juga, indonesia memiliki presiden baru dan kemudian memiliki rumusan kerja untuk masa kerjanya yang tertuang dalam nawa cita, sehingga rpjmn 2015-2019 d sebagai berikut: 


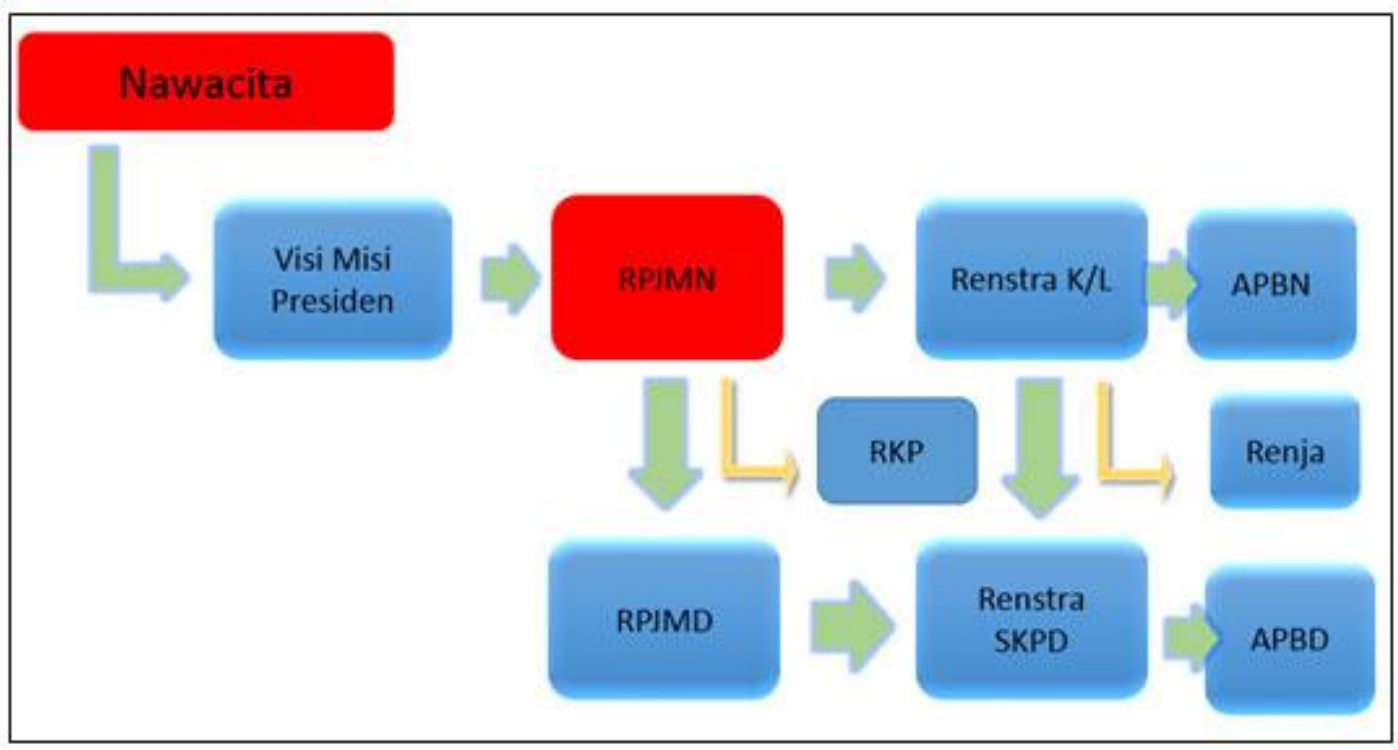

Gambar 3. Kerangka kebijakan pembangunan 2015-2019

Hubungan perencanaan nasional, pusat, dan daerah dalam periode jangka panjang (20 tahun) yang kemudian dijabarkan dalam perencanaan menengah (RPJMN) (5 tahun) adalah sebagai berikut: 


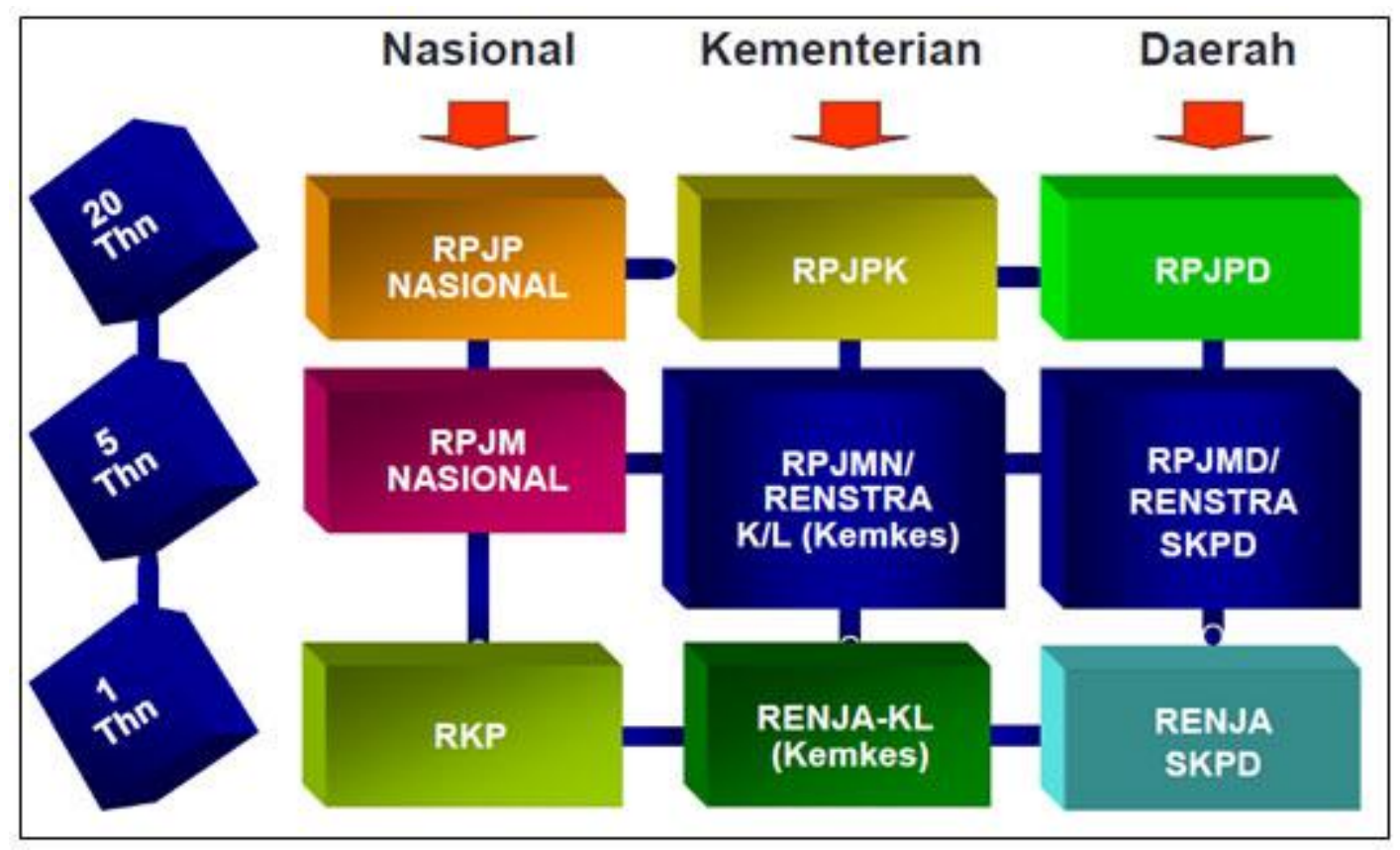

Gambar 4. Hirarki perencanaan

Rpjp nasional digunakan selama 20 tahun dan diterjemahkan oleh kementerian atau lembaga terkait hingga ketingkat daerah. Rpjp kemudian dibagi menjadi rpjm baik nasional, tingkat pusat/kemeterian atau lembaga, hinggga ke daerah. Rpjmn pada tingkat kementerian atau lembaga juga diterjemahkan sebagai rencana strategis atau renstra kementerian/ lembaga. Renstra kementerian atau lembaga inilah yang pada tingkat daerah diterjemahkan masing-masing oleh skpd dalam bentuk renstra SKPD.

Berikut rpjpn indonesia tahun 2005-2025 yang digunakan sebagai acuan pembangunan diseluruh kementerian atau lembaga maupun ditingkat daerah. 


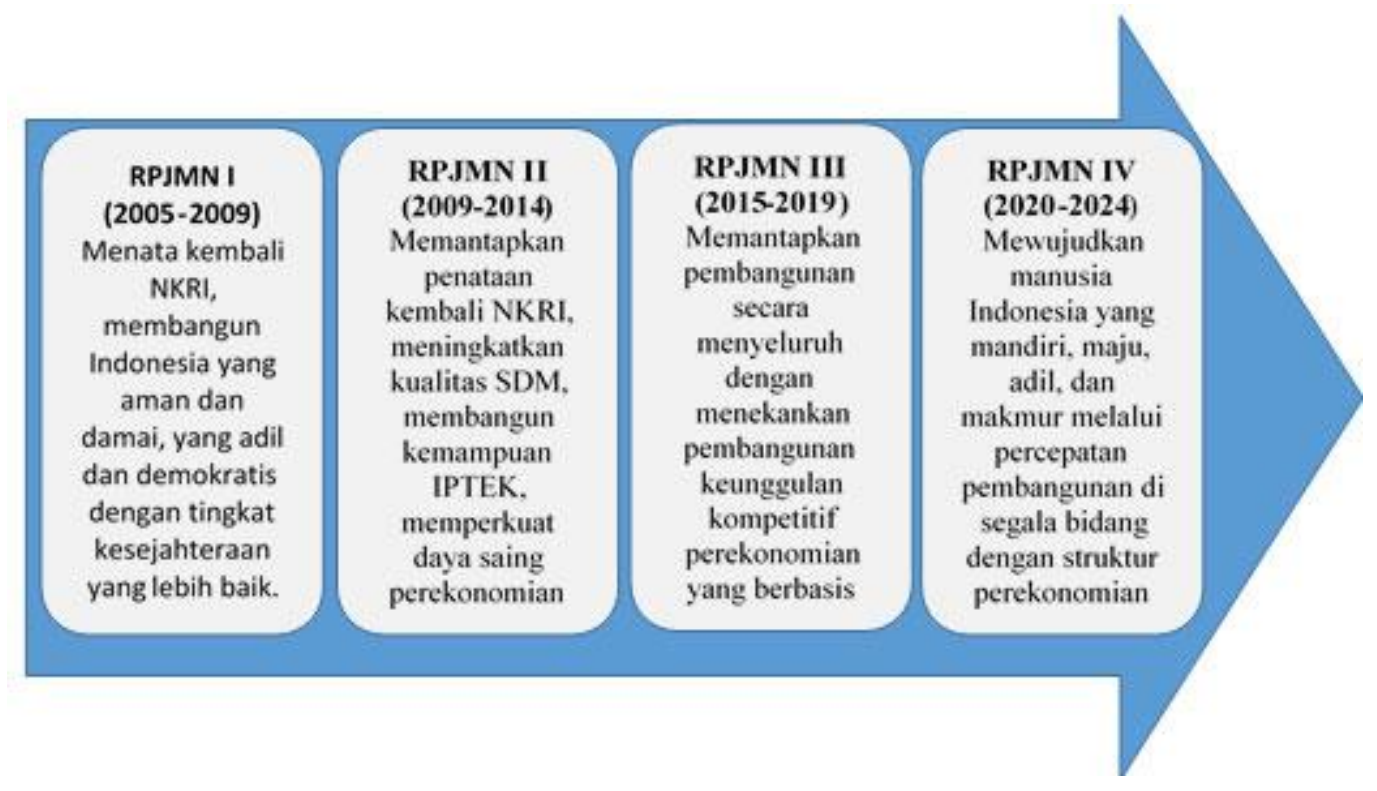

Gambar 5. RPJP Indonesia 2005-2025

Berikut adalah proses keluarnya rpjmn. Dengan melihat proses ini maka dapat diperhatikan aspek waktu dan momen dalam memberikan masukan dan rekomendasi untuk rpjmn selanjutnya: 


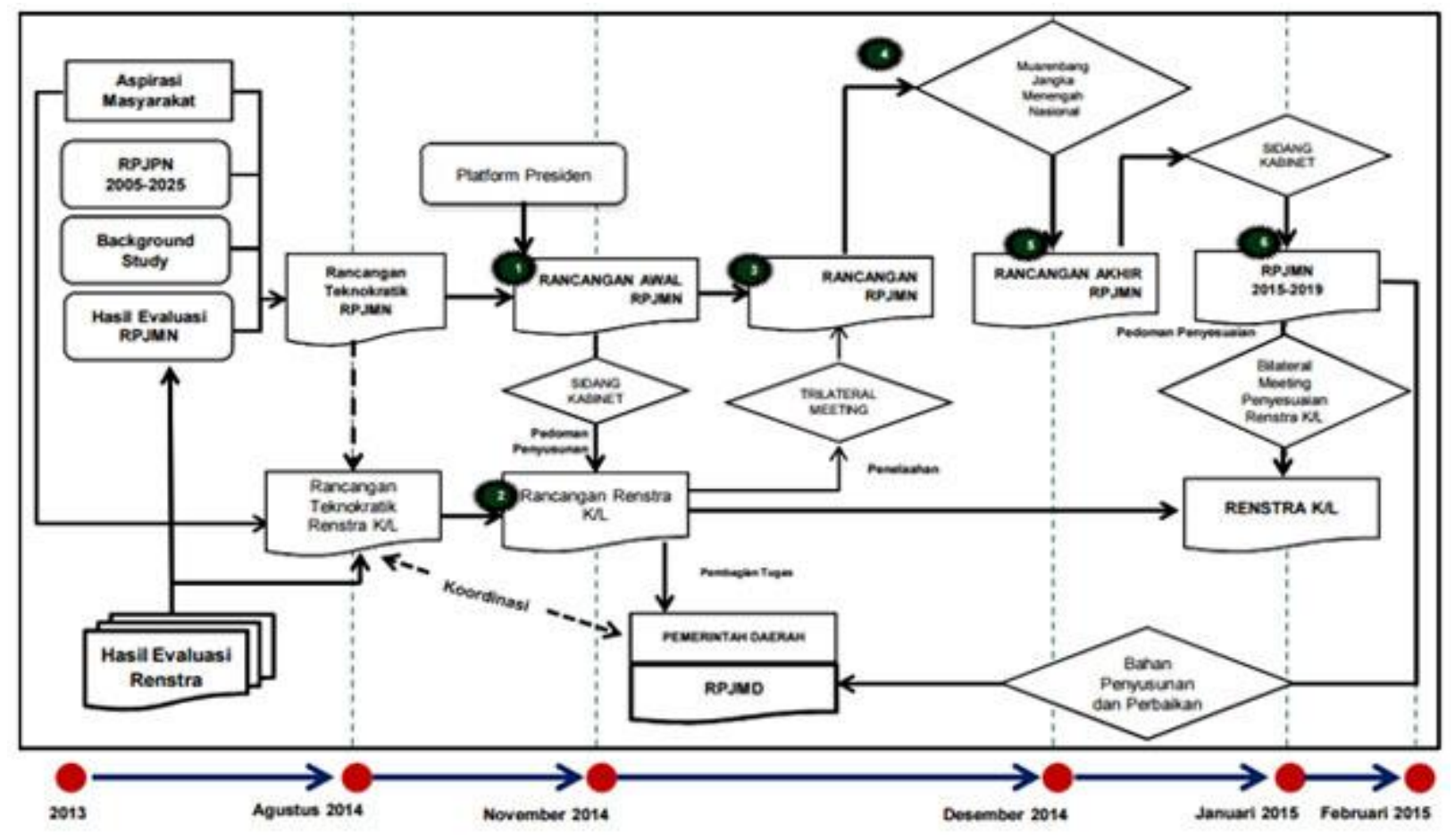

Gambar 6. Alur penyusunan RPJM

Jadi dapat di simpulkan bahwasaannya perencanaan sangat penting dilakukan sebelum mekalukan pembangunan agar pembagunan dapat dilakukan dengan baik, dan tujuan dari pembangunan itu dapat tercapai dengan maksimal, serta menghindari terjadinya tumpang tindih dari pembangunan anatar pusat dengan daerah sehingga pembangunan dapta dilaksanakan secara merata, dan juga perencanaan mampu meminimalisir kerugian dan dampak buruk dari pembangunan, seperti estimasi biaya,dampak lingkungan dan cara mengatasi jika hal hal yang tidak diinginkan terjadi. 


\section{H. Perencanaan Yang Baik}

Perencanaan yang baik adalah perencanaan yang dilakukan dengan tetap mendasarkan pada data dan informasi yang akurat, valid dan akuntabel dengan tetap mempertimbangkan sumber daya dan potensi yang dimiliki. Dalam proses menyusun perencanaan tentunya dilakukan dengan terlebih dahulu mengkaji indikator-indikator perkembangan di daerah diantaranya indeks pembangunan manusia (ipm), tingkat inflasi, pertumbuhan ekonomi, tingkat pengangguran, tingkat kemiskinan dan beberapa indikator lainnya terutama kondisi keuangan daerah

Syarat- syarat perencanaan yang baik;

a) Berdasarkan pada alternative

Agar dapat menetapkan perencanaan yang baik maka sebelumnya agar disusun berbagai alternative, misalnya untung dan rugi kelebihan dan kekurangannya, kendala dan dukungannya, sehingga dapat menentukan perencanaan yang paling baik.

b) Harus realistis

Perencanaan tidak realistis, mungkin baik diatas kertas saja akan tetapi tidak dapat dilaksanakan dalam prakteknya. Misalnya : keterbatasan dalam teknologi, keterbatasan sumber dana, tenaga kerja, dsb.

c) Harus ekonomis

Disamping keterbatasan diatas, juga harus mempertimbangkan tingkat ekonomis dalam suatu rencana. Hindarkan faktor pemborosan, biaya, waktu, tempat, dsb.

d) Harus luwes (fleksibel)

Dalam hal ini perencanaan harus fleksibel, artinya setiap saat dapat dievaluir sesuai dengan perkembangan organisasi, situasi dan kondisi pada waktu tersebut. Pada dasarnya perencanaan itu disusun berdasarkan hasil penelitian sebelumnya, namun dalam prakteknya sering terjadi berbagai penyimpangan yang tidak dapat dihindarkan.

e) Didasari partisipasi

Dalam pembuatan perencanaan hendaknya dapat diikutkan berbagai pihak untuk 
memperoleh masukan (input) agar lebih sempurna. Dengan adanya partisipasi, perusahaan akan memperoleh manfaat ganda, karena disamping rencana menjadi lebih baik, juga dapat menambah semangat kerja para karyawan (karena merasa).

Ciri-ciri perencanaan yang baik

a. Simpel, sederhana dan mudah dimengerti.

b. Fleksibel. Rencana yang baik haruslah dapat menyesuaikan diri dengan keadaan yang selalu berubah-ubah.

c. Stabil yaitu tidak perlu selalu mengalami perombakan dan perubahan.

d. Faktual. Dibuat berdasarkan fakta-fakta yang ada dan diselaraskan pula dengan kejadian-kejadian yang akan timbul dalam tindakan pelaksanaannya.

e. Rasional yaitu dibuat atas dasar pemikiran yang sehat, ilmiah dan dapat dipertanggung-jawabkan.

f. Kontinyu yakni dipersiapkan untuk tanda-tanda yang terus-menerus dan berkelanjutan.

g. Dinamis. Salah saru ciri perencanaan yang baik, apabila sifatnya dinamis. Perencanaan dibuat dan dipersiapkan untuk memikirkan peningkatan perbaikan dan pembaharuan dalam mencapai kemajuan dan kesempurnaan pada masa yang akan datang.

h. Praktis dan pragmatis artinya planning mampu dilakukan dan dicapai serta dapat mendukung program organisasi.

i. Akurat artinya di buat secara terperinci dan mendetail dan dirumuskan segala aspek organisasi, tata kerja, metode kerja, penggunaan tenaga kerja, pembiayaan, jadwal waktu, target hasil dari sistem pengawasan.

j. Sistematik artinya suatu perencanaan itu dipandang baik apakah susunannya teratur baik. 


\section{BAB IV \\ PERENCANAAN PEMBANGUNAN EKONOMI}

\section{A. Perlunya Perencanaan Ekonomi Di Negara Sedang Berkembang.}

I Dalam Ilmu Ekonomi mengenal teori keseimbangan yang stabil (stabile equilibrium). Teori ini menyebutkan bahwa jika terjadi perubahan dari keadaan seimbang, maka akan timbul suatu reaksi dalam bentuk perubahan ke arah yang berlawanan dengan keadaan yang pertama, sehingga akhirnya keadaan akan kembali kepada keseimbangan semula.

Teori ini ternyata tidak dapat diterapkan pada sistem sosial. Dalam sistem sosial tidak terdapat kekuatan yang secara otomatis mengembalikan keadaan yang tidak stabil ke keadaan stabil. Dalam kenyataan dapat kita lihat bahwa jika terjadi suatu perubahan sosial dalam sistem sosial, maka perubahan tersebut akan menimbulkan perubahan lain yang membawa sistem tersebut semakin jauh dari keadaan semula. Hal ini menunjukkan bahwa suatu proses sosial cenderung komulatif, bahkan dengan laju yang semakin cepat.

Ada dua metoda untuk memotong lingkaran setan kemiskinan tersebut. Pertama, melakukan pembangunan yang terencana dengan mencari modal dari luar negeri yang disebut industrialisasi yang diproteksi, dan kedua adalah dengan cara menghimpun tabungan wajib yang disebut industrialisasi dengan kemampuan sendiri.

Dasar pemikiran timbulnya perencanaan di NSB itu adalah untuk memperbaiki dan memperkuat mekanisme pasar. Mekanisme pasar di NSB biasanya belum sempurna karena ketidaktahuan dan ketidakbisaan NSB-NSB dengan mekanisme seperti itu, sehingga perekonomian didominasi oleh sektor non-uang. Pasar produk, faktor produksi, modal dan uang tidak terorganisir dengan baik sehingga keseimbangan antara permintaan dan penawaran agregat atas barang dan jasa tidak terjadi. Untuk menghapuskan ketidaksempurnaan pasar tersebut, yakni agar mobilisasi dan pemanfaatan sumber-sumber dapat lebih efisien, maka diperlukan suatu perencanaan.

\section{B. Masalah Pokok Dalam Perencanaan Ekonomi}

Selama dua dekade sejak tahun 1950, dunia ditandai dengan munculnya bangsa-bangsa yang belum maju sebagai suatu kekuatan ekonomi dan politik yang berkembang cukup pesat dalam dunia internasional. Negara-negara sedang 
berkembang (NSB) tersebut semakin meningkat aspirasinya untuk mengejar ketertinggalan ekonominya di negara-negara maju. Hal ini ditunjukkan oleh diterimanya secara universal perencanaan pembangunan sebagai sarana utama untuk mencapai pertumbuhan ekonomi yang cepat.

Seperti yang telah disebutkan di muka, pengertian perencanaan ekonomi adalah usaha secara sadar dari suatu pusat organisasi untuk mempegaruhi, mengarahkan, serta dalam beberapa hal bahkan mengendalikan perubahanperubahan variabel-variabel ekonomi yang utama (misalnya GDP, konsumsi, investasi, tabungan dan lain-lain) dari suatu negara atau wilayah tertentu selama periode waktu tertentu sesuai dengan dengan tujuan-tujuan yang telah ditetapkan sebelumnya. Jadi inti dari perencanaan ekonomi adalah gagasan-gagasan tentang pengaruh, pengarahan dan pengendalian dari masalah-masalah pokok dalam pembangunan ekonomi.

\section{a. Masalah Pokok Dalam Pembangunan Ekonomi}

Untuk mengamati dan mengidentifikasi masalah-masalah pokok dalam pembangunan menyangkut antara lain:

\section{Masalah Kemiskinan}

Pada umumnya suatu kemiskinan akan tercermin dari pendapatan perkapita masyarakat dalam suatu negara dimana konsumsi utamanya adalah untuk memenuhi kebutuhan makanan. Keadaan tersebut menjadi masalah pokok dalam perencanaan pembangunan di sebagian negara-negara berkembang, karena perencanaan pembangunannya harus bisa merumuskan kegiatan-kegiatan dan usaha-usaha untuk keluar dari suatu lingkaran setan kemiskinan yang ada. Suatu kenyataan di negaranegara berkembang bahwa tingkat produktivitas masyarakatnya sangat rendah yang disebabkan oleh kurangnya sumber-sumber pembangunan, pasarnya tidak sempurna dan keadaan ekonomi yang masih belum maju.

Menurut Rognar Nurkse, lingkaran setan kemiskinan itu dapat dilihat dari beberapa segi, yaitu (a) segi permintaan, (b) segi penawaran, dan (c) segi keterbelakangan masyarakat serta sumber kekayaan alam yang dimiliki. 


\section{a). Segi Permintaan}

Rendahnya tingkat pendapatan nyata menyebabkan jumlah permintaan menjadi rendah, sehingga pada gilirannya tingkat investasi pun rendah. Tingkat investasi yang rendah kembali menyebabkan kurangnya modal dan rendahnya produktivitas yang mengakibatkan rendahnya pendapatan. Hal tersebut dapat digambarkan sebagai berikut :

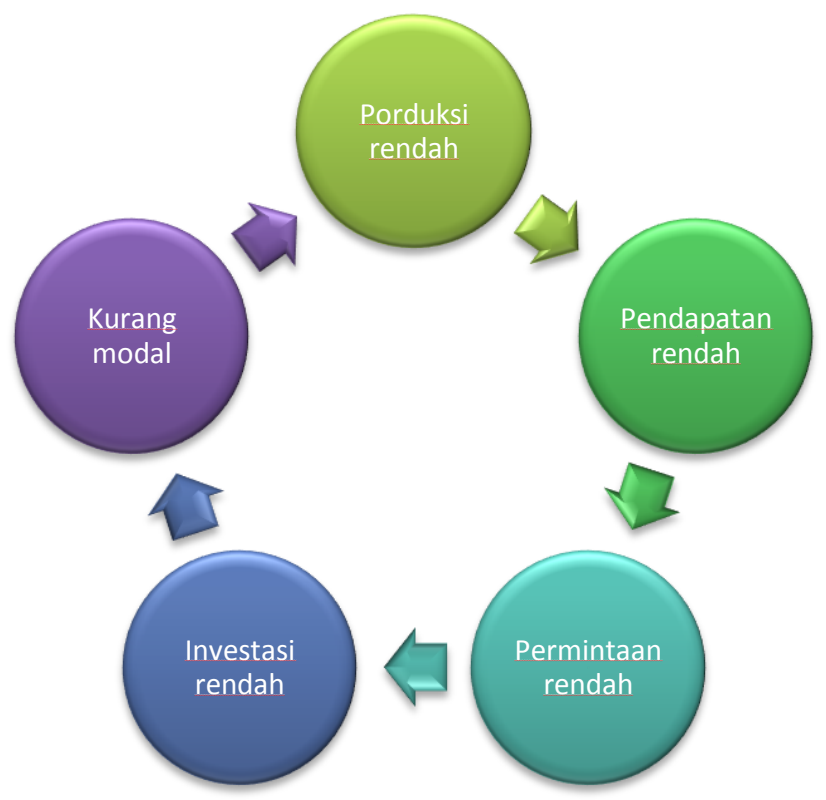

Gambar. 6.1 Permintaan Rendah Akibat Masalah Pendapatan Rendah

\section{b) Segi Penawaran}

Produktivitas rendah tercermin di dalam pendapatan nyata yang rendah. Pendapatan nyata rendah berarti tingkat tabungan rendah, sehingga tingkat investasi rendah, karena kekurangan modal. Kekurangan modal itu akhirnya bermuara kembali pada tingkat produktivitas yang rendah. Keadaan ini dapat digambarkan sebagai berikut :

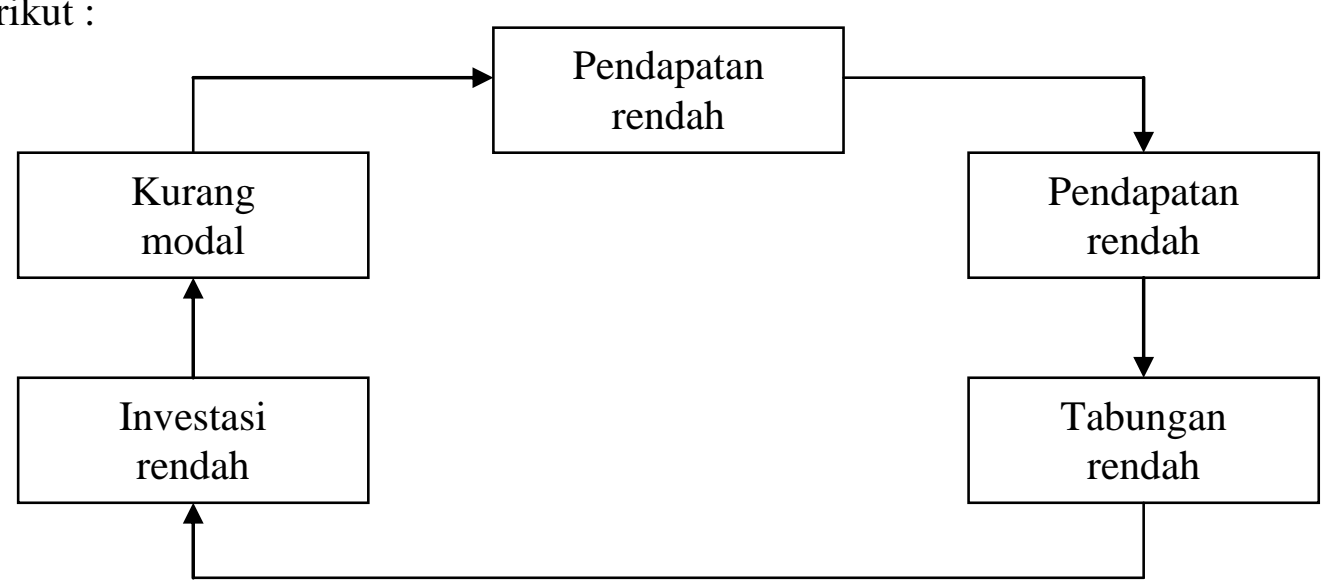




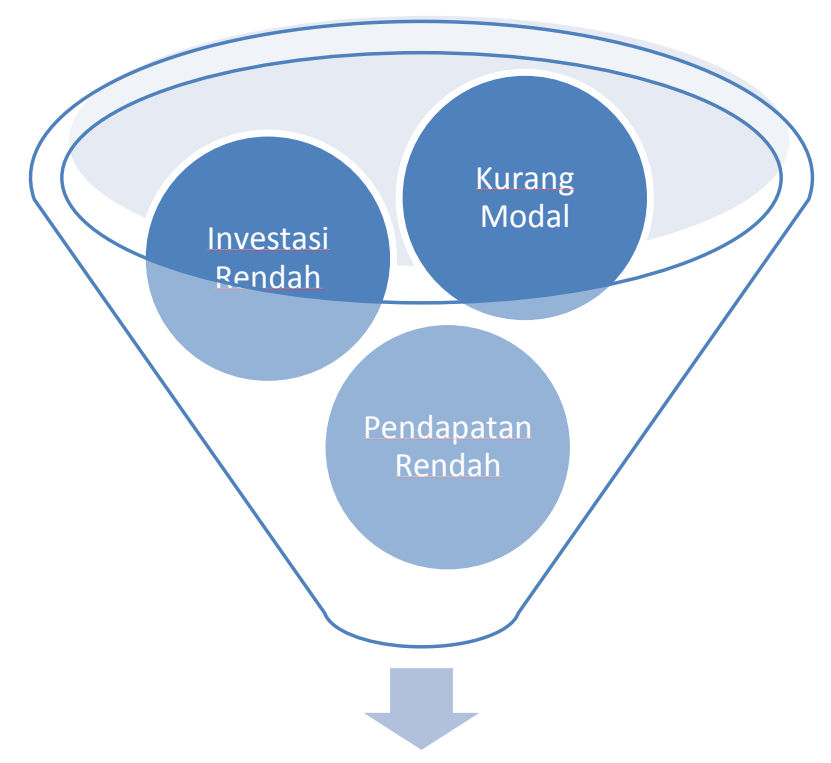

\section{Tabungan Rendah}

c) Segi Keterbelakangan Masyarakat dan Sumber Kekayaan Alam Yang Dimiliki

Pengembangan sumber kekayaan alam suatu negara sangat tergantung kepada kemampuan penduduk dalam mengelolanya. Apabila keadaan penduduk sangat terbelakang, maka sumber kekayaan alam tersebut tidak bisa dimanfaatkan semaksimal mungkin. Sebaliknya, keterbelakangan sumber kekayaan itu sendiri akan meyebabkan keterbelakangan penduduk negara yang bersangkutan. Keadaan tersebut dapat terlihat pada gambar di bawah ini.

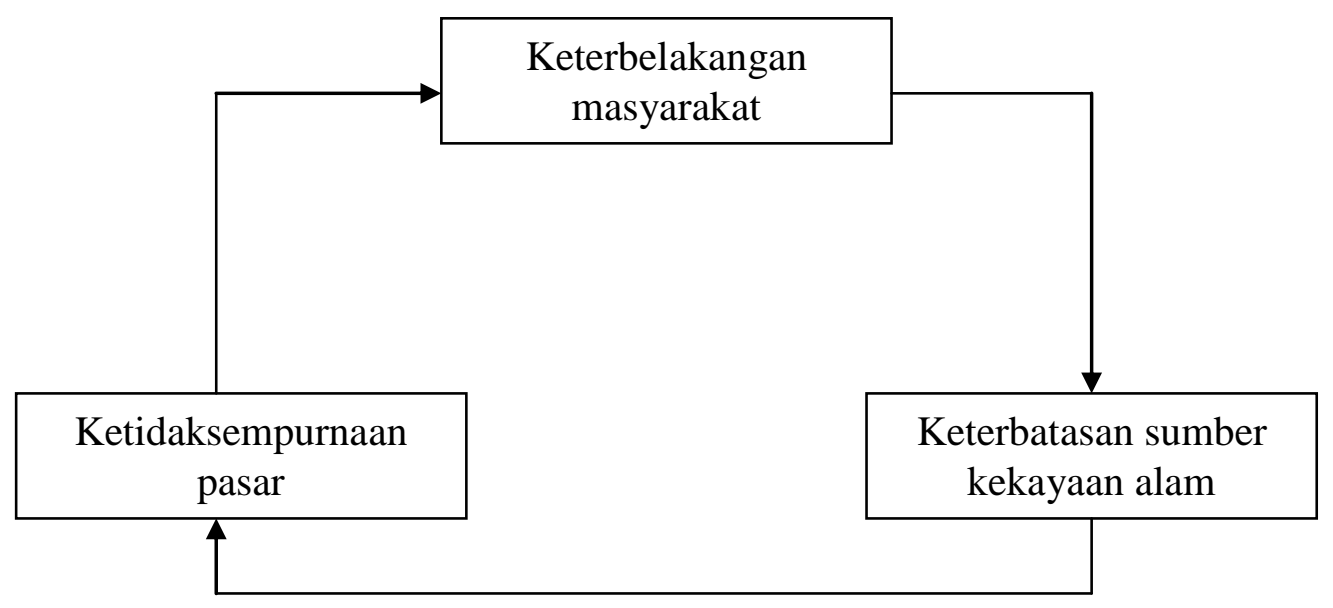




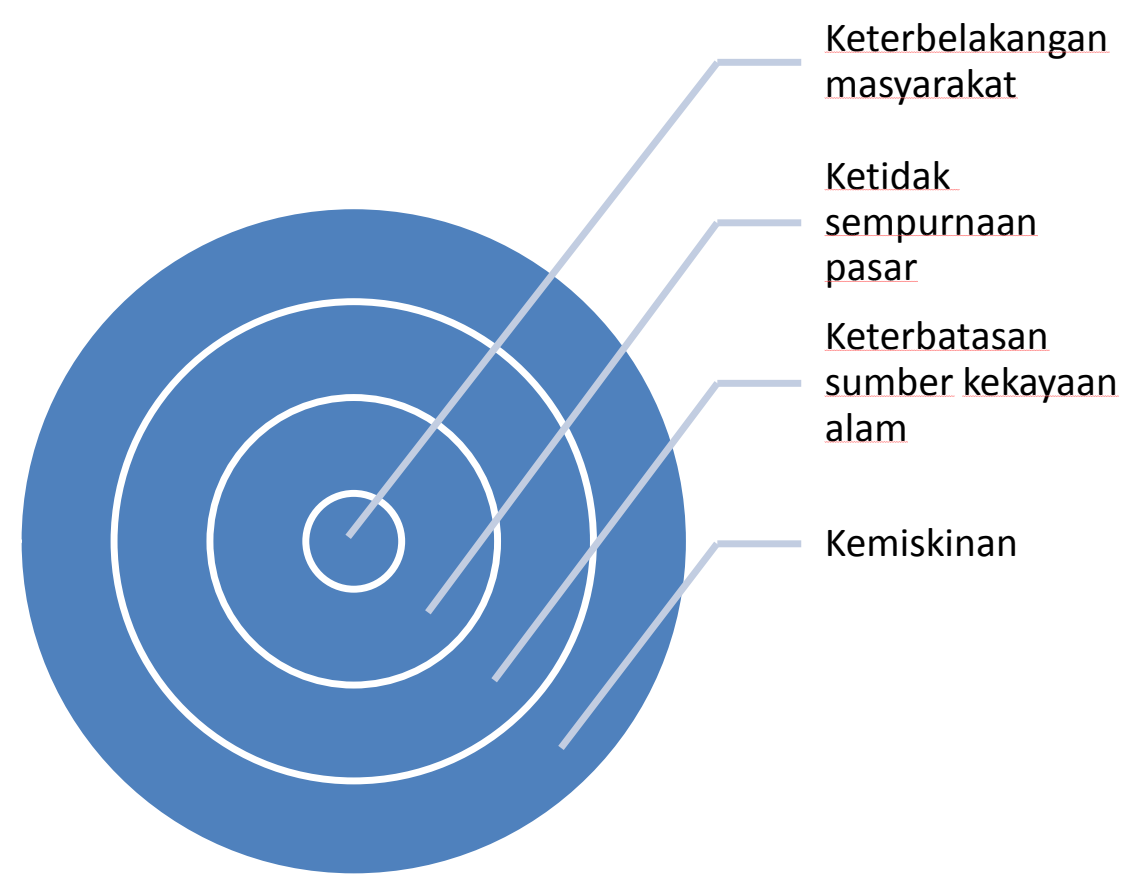

Jadi suatu kemiskinan tersebut harus diatasi, artinya lingkaran setan kemiskinan itu harus diputus. Karena selagi masyarakat suatu negara masih tetap miskin, maka akan tetap miskin. Tanda-tanda kemiskinan itu sangat jelas terlihat dalam kehidupan sehari-hari seperti; (i) Kekurangan gizi, (ii) Lingkungan hidup yang kumuh, (iii) Kurangnya pendidikan masyarakat, (iv) Tingginya tingkat kematian bayi dan lain-lain

Jelaslah sekarang bahwa suatu kemiskinan selalu memberi dampak yang sangat menjurus ke arah menurunnya pendapatan, pendidikan dan harkat serta rasa percaya diri dari masyarakat suatu negara. Lebih jauh dapat dikemukakan bahwa meskipun kebutuhan dasar minimum sudah terpenuhi tetapi jauh lebih rendah dibandingkan dengan masyarakat lainnya, dalam hal ini keadaan tersebut masih merupakan kemiskinan.

\section{Masalah Ketimpangan}

Masyarakat dari negara manapun di dunia selalu mengharapkan adanya pemerataan dalam pembangunan yang dilaksanakan, terutama pada negara-negara dimana masyarakatnya ikut berpartisipasi secara aktif. Namun kenyataannya, ketidak meratanya atau ketimpangan pembangunan itu sering kali terjadi, seperti ketimpangan distribusi pendapatan dan ketimpangan distribusi pembangunan.

Ketimpangan distribusi pendapatan ini biasanya sering terjadi karena tingginya tingkat pengangguran pada negara yang bersangkutan, sebagai akibat dari 
pemilihan prioritas pembangunan yang kurang tepat. Pembangunan hanya diarahkan kepada usaha-usaha untuk mencapai pertumbuhan ekonomi yang tinggi tanpa memperhatikan faktor-faktor lainnya. Padahal pertumbuhan ekonomi yang tinggi saja belum dapat menghasilkan suatu pemerataan pendapatan, sehingga kemungkinan hal tersebut hanya dinikmati oleh segolongan masyarakat tertentu saja. Dalam hal ini, pemilihan prioritas pembangunan yang kurang tepat itu antara lain adalah (a) Pemilihan proyek yang menggunakan teknik padat modal, sedangkan tingkat pengangguran masih tinggi. (b) Pemilihan proyek pengembangan industri, padalhal sebagian besar tenaga kerja terdapat pada sektor pertanian. (c) Dan lain sebagainya.

Sementara itu, ketimpangan distribusi pembangunan umumnya terjadi pada suatu negara yang mempunyai wilayah kekuasaan yang luas sekali. Pembangunan hanya dilakukan pada daerah-daerah tertentu saja, baik pembangunan proyek-proyek yang meningkatkan hasil produksi nasional maupun proyek-proyek sektor masyarakat. Dengan demikian, pembangunan di satu daerah berkembang dengan pesat, sehingga masyarakat daerah itu akan dapat menikmati secara langsung hasil partisipasi aktif mereka dalam pembangunan.

Sebaliknya, masyarakat di daerah yang lain belum bisa menikmati hasil partisipasi aktif mereka dengan penuh seperti masyarakat pada daerah lainnya karena perkembangan pembangunan belum memadai. Keadaan tersebut bisa terjadi antara lain karena pemilihan prioritas pembangunan pada tahapan pembangunan tertentu. Keadaan daerah dan masyarakatnya yang memerlukan ekstra pembangunan dibandingkan dengan daerah lainnya, pemilihan prioritas yang kurang tepat dan lain sebagainya.

Masalah ketimpangan tersebut perlu diatasi dengan cepat, karena keadaan itu bisa menimbulkan kerawanan sosial. Jurang antara si kaya dan si miskin semakin lebar. Begitu pula, kemajuan suatu daerah akan meninggalkan daerah lainnya jauh di belakang. Keadaan-keadaan tersebut perlu mendapat perhatian yang serius, karena kalau dibiarkan maka ketimpangan itu akan menjadi faktor penghalang pembangunan.

\section{Masalah Kependudukan}

Masing-masing negara di dunia ini umumnya memiliki masalah di bidang kependudukan yang tidak hanya menyangkut jumlahnya tetapi juga mencakup masalah kualitas manusia dan kelengkapan materialnya. Masalahnya jumlah penduduk tergambar dari laju pertumbuhan yang tinggi dalam hal mana dipengaruhi 
oleh tingkat kelahiran dan tingkat kematian pada suatu negara. Adanya kemajuan pembangunan akan menimbulkan dilema di bidang ini, yaitu di satu pihak negara tersebut menginginkan laju pertumbuhan penduduk yang rendah, tetapi di lain pihak tingkat kematian menjadi berkurang di samping tingkat kelahiran yang masih tetap tinggi karena ada pandangan masyarakat bahwa banyak anak akan membawa kemakmuran.

Apabila laju pertumbuhan penduduk yang tinggi itu tidak diiringi dengan perluasan kesempatan kerja, maka akan terjadi pengangguran tenaga kerja. Edgar O. Edwars mengemukakan bahwa terdapat lima bentuk pengangguran di negara-negara berkembang yaitu :

(1) Pengangguran terbuka, yaitu mereka yang secara sadar tidak mau bekerja karena menuntut pekerjaan yang lebih baik atau sesuai dengan tingkat pendidikannya dan mereka yang terpaksa tidak bekerja karena tidak tersedia lapangan pekerjaan padahal mereka mau bekerja.

(2) Pengangguran semu, yaitu mereka yang bekerja kurang dari apa yang semestinya mereka kerjakan.

(3) Kelihatannya aktif tetapi tidak produktif yaitu mereka yang tidak digolongkan ke dalam bentuk pengangguran seperti pengertian diatas, akan tetapi karena adanya usaha-usaha alternatif yang menggunakan "tanda waktu", seperti :

a. Pengangguran semu yang terselubung; banyak orang-orang yang kelihatannya bekerja karena adanya batasan waktu, seperti bekerja pada kantor atau sektor lain yang memiliki jam kerja tertentu. Sebenarnya pekerjaan yang mereka lakukan tersebut tidak memerlukan waktu selam batasan waktu tertentu itu.

b. Pengangguran tersembunyi; yaitu mereka yang bekerja pada pekerjaan pilihan kedua, seperti pekerjaan di bidang pendidikan dan rumah tangga, karena tidak terdapat kesempatan-kesempatan pekerjaan yang sesuai dengan tingkat dan di bidang pendidikannya.

c. Pensiun yang dipaksakan yaitu mereka yang harus berhenti bekerja karena ketentuan yang berlaku untuk memberi kesempatan kerja bagi mereka yang harus diangkat dari bawah. Sebenarnya para pensiunan tersebut masih merupakan tenaga yang produktif. 
(4) Tenaga yang merugikan, yaitu mereka yang bekerja mungkin melebihi waktu yang seharusnya, tetapi intensitas kerjanya sangat merugikan karena tenaga kerja tersebut kurang gizi atau kurang sehat.

(5) Tenaga-tenaga yang tidak produktif, yaitu mereka yang bisa memberikan hasil sebagai sumber-sumber daya manusia yang diperlukan untuk pekerjaan produktif, tetapi mereka bekerja dalam kondisi yang kurang memadai untuk mencapai hasil yang baik, bahkan untuk kebutuhan hidup mmereka yang pokok belum terpenuhi.

Disadari atau tidak bentuk-bentuk pengangguran tersebut terjadi di negaranegara berkembang, bahkan di negara-negara maju tetapi dalam persentase yang kecil sekali. Hal tersebut harus diatasi secepatnya karena bisa menimbulkan lingkaran yang tidak berujung pula. Pengangguran tinggi akan menimbulkan pendapatan yang rendah yang berarti muncul kemiskinan. Hal itu menyulitkan untuk meningkatkan kualitas manusianya, sehingga tingkat produktivitasnya rendah dan pada gilirannya akan sulit menciptakan lapangan kerja baru yang berarti pula masalah pengangguran tetap tidak bisa diatasi.

Disamping itu, dengan tingginya laju pertumbuhan penduduk akan menyulitkan bagi peningkatan pembangunan di masa datang. Sebab hal tersebut akan menyerap setiap kenaikan pendapatan nasional yang dihasilkan oleh pembangunan, sehingga usaha untuk mencapai tingkat pertumbuhan ekonomi yang positif menjadi percuma. Hal ini sangat erat hubungannya dengan masalah kualitas manusia dan kelengkapan materialnya.

Untuk meningkatkan kualitas manusia disini dibutuhkan pembangunan sarana pendidikan dan kesehatan. Melalui pendidikan dapat dikembangkan cara berpikir masyarakatnya disamping meningkatkan ilmu pengetahuan dan keterampilan yang sangat bermanfaat bagi pembangunan itu sendiri. Sementara itu, sarana kesehatan sangat berguna untuk menciptakan masyarakat yang sehat dan bergizi sehingga sumber daya ini bisa meningkatkan produktivitasnya. Dengan demikian, setiap individu masyarakat akan dapat mempunyai kesempatan minimal untuk memperoleh pendidikan dasar dan perawatan kesehatan yang memadai.

Kelengkapan material dari masyarakat yang memadai tidak hanya menyangkut bahan makanan pokok, tetapi juga mencakup penyediaan kebutuhan perumahan dan sarana phisik lainnya. Apabila laju pertumbuhan penduduk tersebut tidak ditekan sesuai dengan yang diharapkan, maka sulit untuk dibayangkan bagaimana cara 
pemerintah sebagai pengelola negara dapat untuk memenuhi kelengkapan material setiap individu masyarakatnya. Sedangkan kenaikan pendapatan nasional telah diserap habis oleh kenaikan jumlah penduduk yang tinggi tersebut.

\section{Masalah Pembentukan Modal}

Kelangkaan modal sudah merupakan salah satu ciri umum dari negara-negara berkembang. Bukan saja persediaan modal yang kurang tetapi tingkat pembentukan modalnya juga sangat rendah. M.L Jhingan mengemukakan di dalam bukunya "The Economics of Development and Planning” bahwa Investasi bruto dari negara-negara terbelakang hanya berkisar antara 5-6\% dari pendapatan nasional bruto, sedangkan di negara maju adalah kira-kira sebesar $15-20 \%$.

Keadaan ini merupakan suatu kesulitan bagi negara-negara berkembang untuk meningkatkan jumlah proyek-proyek pembangunannya. Lebih-lebih kalau ditanamkan pada proyek-proyek padat modal yang membutuhkan modal besar dimana belum termasuk penyediaan dana untuk menutup penyusutan modal dan pengganti peralatan yang sudah rusak serta perawatannya.

Sebagaimana diketahui, pembentukan modal itu dapat dibedakan atas pembentukan modal yang bersumber dari dalam negeri dan dari luar negeri. Pembentukan modal dalam negeri sangat tergantung kepada besar atau kecilnya tabungan masyarakat disamping penerimaan pajak dan penerimaan lainnya. Kecilnya jumlah tabungan masyarakat di negara-negara berkembang adalah karena :

(1) Rendahnya pendapatan perkapita masyarakat

Keadaan ini tidak terlepas dari lingkaran setan kemiskinan yang telah duraikan sebelumnya. Akibat rendahnya pendapatan masyarakat tersebut, jumlah pendapatan yang akan ditabungkan menjadi sedikit.

(2) Rendahnya minat menabung masyarakat

Umumnya di negara-negara berkembang terdapat ketimpangan pemdapatan dimana ada segolongan masyarakat mempunyai pendapatan yang tinggi dan ada pula segolongan masyarakat yang berpenghasilan rendah. Hal tersebut tidak berarti bahwa golongan masyarakat yang berpendapatan tinggi itu akan menyebabkan jumlah tabungan masyarakat secara nasional akan tinggi pula. Sebab golongan ini cenderung untuk menggunakan dananya untuk tujuantujuan spekulatif dan tidak produktif, seperti menyimpan dalam bentuk emas dan permata atau memberi pinjaman dengan suku bunga yang tinggi. Begitu 
pula dengan golongan masyarakat yang berpenghasilan rendah dimana mereka hanya memiliki tabungan sedikit karena kecenderungan yang mengarah kepada penundaan konsumsi untuk masa depan. Tabungan itu nantinya digunakan untuk kebutuhan tak terduga, konsumsi barang mewah atau penggunaan lainnya. Kesemuanya itu terjadi pada dasarnya karena kurangnya minat menabung di kalangan masyarakat itu sendiri.

(3) Adanya kecenderungan untuk menyamai pola konsumsi negara maju

Pada diri setiap orang biasanya terdapat kecenderungan untuk meniru gaya hidup dari tetangga kaya. Kecenderungan inipun terdapat pada orang-orang di negara-negara berkembang untuk menyamai pola konsumsi tinggi di negaranegara maju, sehingga setiap peningkatan pendapatan akan dipergunakan untuk pengeluaran konsumsi mewah. Akibatnya jumlah tabungan menjadi statis atau tidak berarti sama sekali. Sementara itu, mengingat pendapatan perkapita masyarakat di negara-negara berkembang yang masih rendah, maka untuk pembiayaan pembangunan perlu diupayakan pembentukan modal yang bersumber dari luar negeri. Untuk menarik modal dari luar negeri itu bukanlah suatu pekerjaan yang mudah, karena sangat tergantung kepada motivasi politik dan motivasi ekonomi dari negara asal modal terhadap negara modal. Meskipun demikian, perlu diperhatikan bahwa pembentukan modal dari luar negeri haruslah merupakan faktor pelengkap bagi pembiayaan pembangunan keseluruhan.

(4) Masalah Pengelolaan Potensi Kekayaan Alam

Menjadi suatu kenyataan bahwa masing-masing negara memiliki tingkat potensi kekayaan alam yang berbeda-beda karena dipengaruhi oleh letak geografik negara tersebut. Potensi kekayaan alam itu meliputi seluruh sumber kekayaan alam yang dimiliki oleh suatu negara baik di darat, di dalam tanah, di laut maupun di udara. Kekayaan alam yang tersedia di darat antara lain berupa hutan dengan segala kekayaan yang terkandung didalamnya , di dalam tanah antara lain seperti bahan tambang dan sumber panas bumi, di laut seperti hasil-hasil laut dan bahan tambang yang ada di dasar laut, dan di udara seperti sumber panas matahari. Seringkali dikatakan bahwa negara-negara berkembang memiliki kekayaan alam yang kurang sekali. Hal ini sulit untuk dipertanggungjawabkan. Sebagaimana dikemukakan oleh W.A. Lewis dalam bukunya "The Economics of Growth". "Suatu negara yang dianggap miskin 
sumber alam saat ini mungkin dapat dianggap sangat kaya dikemudian hari, tidak saja lantaran diketemukannya sumber-sumber yang tersembunyi, tetapi juga karena penggunaan sumber yang telah diketahui dengan cara baru".Jelaslah bahwa potensi kekayaan alam itu membutuhkan pengolahan dengan teknologi dan ilmu pengetahuan yang mendukung untuk memperoleh hasil yang optimal.

Disamping itu, pengolahan potensi kekayaan alam tersebut perlu mempertimbangkan dampaknya dalam jangka panjang. Suatu pengolahan yang keliru akan mengakibatkan keadaan yang tidak menguntungkan dimasa datang. Sebagai contoh pengolahan hasil hutan, yaitu penebangan kayu-kayu dihutan tanpa diiringi dengan penanaman kembali. Keadaan ini akan memberi keuntungan yang besar karena kayu-kayu tersebut siap untuk diekspor dalam rangka meningkatkan devisa negara. Namun dipihak lain bisa terjadi kerusakan lingkungan sehingga menimbulkan antara lain bahaya erosi sebagai akibat penebangan yang semrawutan disamping usaha penanaman kembali hutan-hutan tersebut tidak berjalan sebagaimana mestinya.

Dari uraian dan perumpamaan tersebut tergambar bahwa meskipun pengolahan potensi kekayaan alam itu bisa memberi keuntungan yang besar dalam jangka pendek tetapi belum tentu akan memberikan hal yang sama untuk jangka panjang bahkan mungkin bisa sebaliknya. Sebab setiap pemanfaatan potensi kekayaan alam itu akan menjadi suatu kekuatan nyata guna mendukung dan menjamin kesinambungan pembangunan di masa selanjutnya.

\section{Masalah Sosial Politik}

Sebagaimana dijelaskan sebelumnya, pembangunan dapat diartikan sebagai suatu perubahan. Berkaitan dengan itu perlu disadari bahwa tidak seluruh kelompok masyarakat bersedia untuk menerima suatu perubahan dengan tangan terbuka. Sebab pembangunan itu, naik secara langsung ataupun tidak langsung akan memberi dampak pada tata kehidupan mereka yang sudah ada. Biasanya mau atau tidak suatu masyarakat menerima pembangunan sangat tergantung pada pandangan hidup yang mereka anut.

Secara umum, pandangan hidup dari masyarakat itu dibedakan atas pandangan hidup yang bersifat terbuka, tertutup dan terbatas. Kelompok masyarakat yang mempunyai pandangan terbuka terhadap pembangunan tidaklah merupakan suatu 
masalah, karena mereka akan bersedia untuk menerima suatu proses perubahan. Kelompok masyarakat ini biasanya telah mengadakan hubungan dengan pihak-pihak diluar kelompok mereka.

Sebaliknya, suatu pembangunan akan sangat sulit diterima atau bahkan ditolak oleh kelompok masyarakat yang memiliki pandangan hidup tertutup. Kelompok masyarakat ini bisa dikatakan jurang atau tidak pernah mengadakan hubungan dengan pihak-pihak luar, sehingga mereka tidak bisa membandingkan tata kehidupan sendiri dengan kelompok masyarakat lainnya. Selain itu, ada pula kelompok masyarakat yang mempunyai pandangan hidup terbatas. Mereka bisa menerima pembangunan tetapi tidak untuk semua perubahan. Umumnya, kelompok ini jauh lebih maju dari kedua kelompok masyarakat sebelumnya, karena mereka sudah bisa membandingkan dan mengkaji perubahan mana yang baik dan mana yang tidak baik bagi kelompoknya. Dengan demikian perubahan yang akan diterima telah diseleksi sedemikian rupa sesuai dengan kebutuhannya.

Menurut laporan PBB dalam "Proces and Problem of Industrialization in Underdeveloped Countries”. Di negara-negara terbelakang terdapat unsur perlawanan sosial terhadap perubahan ekonomi yang berakar pada faktor-faktor kelembagaan seperti tampak dalam: "Stratifikasi pekerjaan yang ketat, yang didukung oleh kepercayaan dan nilai-nilai tradisional; sikap yang "memandang rendah peranan dunia usaha, ketidak cocokan dengan pola hidup dan konsep martabat sosial yang dipegang teguh oleh kelompok berkedudukan tinggi" dan " pengelompokan masyarakat berdasarkan kasta dan kelas, agama dan suku bangsa, tradisi budaya dan pola sosial, warna kulit dan ciri-ciri kedaerahan.

Apabila laporan itu dikaji, maka faktor-faktor tersebut akan menjadi penghalang mobilitas sosial dan geografis. Hubungan antar sesama masyarakat lebih bersifat patrimonial ketimbang bersifat nasional, sehingga timbul sifat pilih kasih yang kadang-kadang jauh dari kenyataan yang wajar dimana perasaan emosional lebih menonjol dari pada logika. Akibatnya tingkat efisiensi diberbagai bidang pembangunan menjadi diabaikan, karena tenaga-tenaga yang potensial tertentu menjadi terlantar dan tidak terpakai secara maksimal, sehingga menjadi kendala bagi pembangunan.

Sementara itu masalah politik merupakan sesuatu yang perlu mendapat prioritas perhatian. Seperti telah diketahui, pelaksanaan pembangunan yang sukses sangat dipengaruhi oleh faktor adanya keamanan politik dari semua golongan negara 
yang bersangkutan. Semua golongan tersebut harus bersatu untuk mendukung dan berpartisipasi dalam pembangunan. Artinya, golongan-golongan politik tersebut tidak hanya memikirkan strategi bagaimana memenangkan ide politik masing-masing, tetapi lebih mengutamakan pemikiran untuk pemecahan masalah yang menyangkut kepentingan nasional dalam rangka mewujudkan tujuan-tujuan pembangunan.

\section{Masalah Administrasi Pembangunan}

Administrasi pembangunan merupakan bagian yang tidak bisa dipisahkan dalam pembangunan suatu negara, karena administrasi pembangunan itu memiliki peran aktif dan berkepentingan terhadap tujuan-tujuan pembangunan, baik dalam perencanaan maupun dalam pelaksanaannya. Bahkan administrasi itu seringkali ikut mempengaruhi tujuan pembangunan yang dirumuskan melalui proses politik.

Mengingat peranannya yang begitu besar, maka permasalahan yang ada didalam adiministrasi pembangunan perlu diatasi dengan cepat. Sebab telah menjadi kenyataan, terutama di negara berkembang, seringkali terjadi birokrasi yang menghambat pelaksanaan pembangunan, bahkan menyebabkan timbulnya biaya yang tinggi disamping kemampuan pelaksanaan yang lebih ditujukan kepada segi memerintah dan menjamin tertib pelaksanaan ketentuan atau hukum yang berlaku. Dengan demikian pembangunan, di negara tersebut tidak menjadi efisien dan efektif.

\section{Proses Perencanaan Dalam pembangunan Ekonomi}

Dalam rangka melakukan suatu perencanaan pembangunan yang lengkap dan konsisten serta sesuai dengan pandangan politik yang dianut, diperlukan suatu lembaga atau badan perencanaan yang langsung berada dibawah kepala pemerintahan negara tersebut. Badan inilah yang bertanggung jawab dan melakukan kegiatankegiatan perencanaan yang merupakan suatu proses berkesinambungan seperti berikut:

a. Identifikasi secara menyeluruh

Tujuannya adalah untuk mengetahui keadaan dan perkembangan yang menyeluruh dari berbagai bidang pembangunan sehingga bisa ditentukan kegiatankegiatan dan usaha-usaha apa yang harus dilakukan. Hal ini sering disebut sebagai studi pendahuluan dalam melakukan suatu perencanaan yang sangat bermanfaat untuk 
memperjelas keadaan menyeluruh dari suatu negara, yang bisa dikaji melalui data dan informasi tentang keadaan masa lalu dan masa sekarang. Dengan demikian, hasil studi pendahuluan ini akan dapat menggambarkan masalah-masalah pokok yang sedang dihadapi, apa-apa hasil pembangunan yang telah dicapai dan apa-apa yang masih perlu dilanjutkan, kendala-kendala apa yang perlu diatasi, kesempatan-kesempatan apa yang harus dimanfaatkan secara maksimal dan potensi-potensi apa yang dapat dikembangkan lebih lanjut. Disamping itu, sekiranya keadaan menyeluruh tersebut belum jelas, maka akan dapat ditentukan perlunya suatu penelitian terlebih dahulu.

\section{b. Peramalan Masa Datang (Forcasting)}

Hal ini dilakukan adalah untuk memperkirakan keadaan dimasa datang atas dasar data dan informasi yang tersedia tentang masa lalu dan masa sekarang dengan menggunakan proyeksi-proyeksi tertentu. Dengan demikian, akan dapat diketahui kemungkinan-kemungkinan yang akan terjadi dimasa datang, baik mengenai kemungkinan yang positif maupun kemungkinan yang negatif. Kemungkinan positif itu adalah antara lain perkiraan perluasan kesempatan kerja, perkiraan pertambahan hasil produksi nasional, perkiraan pertambahan hasil ekspor perkiraan laju pertumbuhan penduduk.

Sebaliknya kemungkinan yang negatif adalah seperti perkiraan penurunan hasil pertanian akibat sebagian besar lahannya telah dipergunakan untuk perumahan rakyat, penurunan nilai ekspor karena harga barang-barang ekspor di pasaran internasional menunjukkan kecenderungan menurun dan lain sebagainya. Disamping itu dapat pula diperkirakan kemungkinan timbulnya masalah-masalah yang bisa menjadi kendala bila tidak dapat diatasi. Berkaitan dengan ini, hal tersebut bisa dicarikan jalan keluarnya lebih dini sehingga tidak mengganggu kelancaran pembangunan.

\section{c. Penentuan Tujuan}

Dalam proses perencanaan pembangunan, tahapan ini merupakan hal yang sangat menentukan, karena disinilah ditentukan arah dari berbagai kegiatan dan usaha yang dilakukan. Tujuan itu harus jelas dan dapat dicapai berdasarkan kemungkinankemungkinan yang rasional. Suatu tujuan yang tidak jelas dan tidak dapat dicapai akan sulit atau bahkan tidak mungkin untuk diwujudkan dengan baik. Sebagai contoh, laju pertumbuhan ekonomi yang hendak dicapai adalah $10 \%$ untuk tahun mendatang. 
Hal ini sulit untuk dicapai mengingat laju pertumbuhan penduduk adalah sebesar $5 \%$ dan tingkat produktivitas nasional yang masih rendah, serta keadaan perekonomian dunia yang sedang mengalami masa depresi.

Tujuan itu ditentukan haruslah berdasarkan keadaan yang sebenarnya dan tidak muluk-muluk. Biasanya tujuan dipengaruhi oleh nilai-nilai politik, budaya dan kondisi sosial masyarakat dari negara yang bersangkutan. Meskipun demikian, perlu ditentukan disini bahwa tujuan itu harus mengangkut kepentingan masyarakat dan negara, bukan meliputi kepentingan satu atau beberapa golongan tertentu saja.

\section{d. Penetapan Strategi Untuk Mencapai Tujuan}

Setelah diketahui dengan jelas tujuan yang hendak dicapai, maka ditetapkan strategi pencapaiannya, yaitu melalui penyusunan suatu kerangka menyeluruh atau kerangka makro berdasarkan asas konsistensi dan prioritas secara terkoordinasi. Pengertian arah konsistensi dan prioritas disini tercermin dari usaha untuk menyeimbangkan kegiatan antar sektor pembangunan sedemikian rupa yang disesuaikan dengan kemampuan negara yang terbatas, melalui penentuan prioritas pembangunan. Dari kerangka makro yang disusun itu akan dapat diketahui bagaimana pengaruh dari hubungan-hubungan beberapa variabel bidang pembangunan dimana hal tersebut akan terlihat pada parameter masing-masing variabelnya. Sebagai contoh dapat dikemukakan beberapa strategi pembangunan, yaitu (a) Strategi pertumbuhan ekonomi, yang ditujukan untuk meningkatkan pendapatan perkapita (b) Strategi pertumbuhan ekonomi dan pemerataan pembangunan, yang ditujukan tidak hanya untuk meningkatkan pendapatan perkapita tetapi juga meningkatkan pemerataannya. (c) Strategi pemenuhan kebutuhan dasar, yang ditujukan untuk meningkatkan pendapatan perkapita dari kelompok penduduk yang berada dibawah garis kemiskinan sehingga kelompok penduduk ini bisa memenuhi kebutuhan pokoknya. (d) Perumusan Kebijakan

Pada tahap ini, perencanaan pembangunan telah mengarah kepada perumusan yang bersifat sektoral sejalan dengan strategi pembangunan yang telah ditetapkan. Untuk itu dilakukan pemilihan sektor-sektor prioritas yang hendak dikembangkan sekaligus penentuan sasaran yang hendak dicapai pada masing-masing sektor tersebut. Dalam hal ini perlu disadari bahwa pencapaian sasaran dari berbagai sektor prioritas itu harus didukung oleh kebijakan yang memadai. 
Dengan demikian, para perencana perlu melakukan pengkajian ulang semua kebijakan yang sudah dikeluarkan. Apabila kebijakan itu dinilai sudah tidak relevan lagi atau bahkan menjadi kendala dimasa datang, maka hal tersebut harus disesuaikan. Selanjutnya, jika kebijakan yang telah ada itu dinilai masih kurang, maka perlu dirumuskan suatu kebijakan baru sehingga sasaran-sasaran dari berbagai sektor prioritas tadi bisa diwujudkan sesuai dengan yang diharapkan. Sebagai contoh dapat dikemukakan, antara lain yaitu (i) Pembangunan sektor industri yang mendukung sektor pertanian, guna sekaligus dapat mengembangkan kedua sektor tersebut sehingga diperoleh laju pertumbuhan ekonomi yang memadai. (ii) Pembangunan sektor-sektor modern yang lebih bersifat padat modal untuk mencapai laju pertumbuhan yang tinggi dan cepat. (iii) Pembangunan sektor industri yang memakai teknik padat karya, untuk mencapai laju pertumbuhan ekonomi yang diiringi dengan pemerataan.

\section{e. Penyusunan Program dan Proyek Pembangunan}

Dalam hal ini, para perencana melakukan perencanaan secara terinci mengenai program-program dan proyek-proyek pembangunan yang akan dilaksanakan. Penyusunan itu meliputi, antara lain; (i) Penentuan tujuan atau sasaran yang hendak dicapai. (ii) Pemilihan jenis program atau proyek yang sesuai. (iii) Jangka waktu pelaksanaannya. (iv) Rincian kegiatan dan jadwal pelaksanaan masing-masing kegiatan. (v) Jumlah dan jadwal pembiayaan.(vi) Penentuan pelaksana program atau proyek yang bersangkutan.

\section{f. Pengambilan Keputusan}

Sebagai tahap terakhir dari proses perencanaan dalam pembangunan adalah tahap pengambilan keputusan. Biasanya pengesahan rencana itu secara bertingkat tergantung pada sistem pengambilan keputusan yang dianut oleh negara yang bersangkutan. Ada yang bertingkat-tingkat, mulai dari keputusan tehnis sampai keputusan politik. Atau ada yang langsung merupakan keputusan politik. Meskipun demikian, dalam hal ini yang penting adalah status formal dari pada rencana itu, sehingga bisa memiliki kekuatan hukum dalam pelaksanaannya. 


\section{BAB V \\ PERERENCANAAN PRODUKSI}

\section{A. Pengertian Produksi}

Menurut Wikipedia ensiklopedia, Produksi merupakan suatu kegiatan yang dikerjakan untuk menambah nilai guna suatu benda atau menciptakan benda baru sehingga lebih bermanfaat dalam memenuhi kebutuhan. Kegiatan menambah daya guna suatu benda tanpa mengubah bentuknya dinamakan produksi jasa. Sedangkan kegiatan menambah daya guna suatu benda dengan mengubah sifat dan bentuknya dinamakan produksi barang. Produksi bertujuan untuk memenuhi kebutuhan manusia untuk mencapai kemakmuran. Kemakmuran dapat tercapai jika tersedia barang dan jasa dalam jumlah yang mencukupi. Orang atau perusahaan yang menjalankan suatu proses produksi disebut Produsen. Di dalam kegiatan produksi pasti ada modal. Modal adalah semua alat yang dapat dimanfaatkan untuk menghasilkan barang dan jasa, dengan imbalan berupa bunga modal kepada pemodal. Modal dibagi 4 yaitu (a) Modal tetap. (b) Modal lancar. (c) Modal sendiri. (d) Modal asing. Berdasarkan pengertian tersebut maka produksi mengandung dua hal pokok, yaitu (1) Menciptakan nilai guna. Misalnya, membangun rumah, membuat pakaian, membuat tas, membuat sepeda dan lain sebagainya.(2) Menambah nilai guna. Misalnya, memperbaiki televisi, memperbaiki sepatu, memperbaiki atau memodifikasi mobil/motor, dan lain sebagainya.

Pengertian Perencanaan dan Pengendalian Produksi. Perencanaan Produksi merupakan aktifitas untuk menetapkan produk yang akan diproduksi, jumlah yang dibutuhkan, kapan produk tersebut harus selesai dan sumber-sumber yang dibutuhkan. 


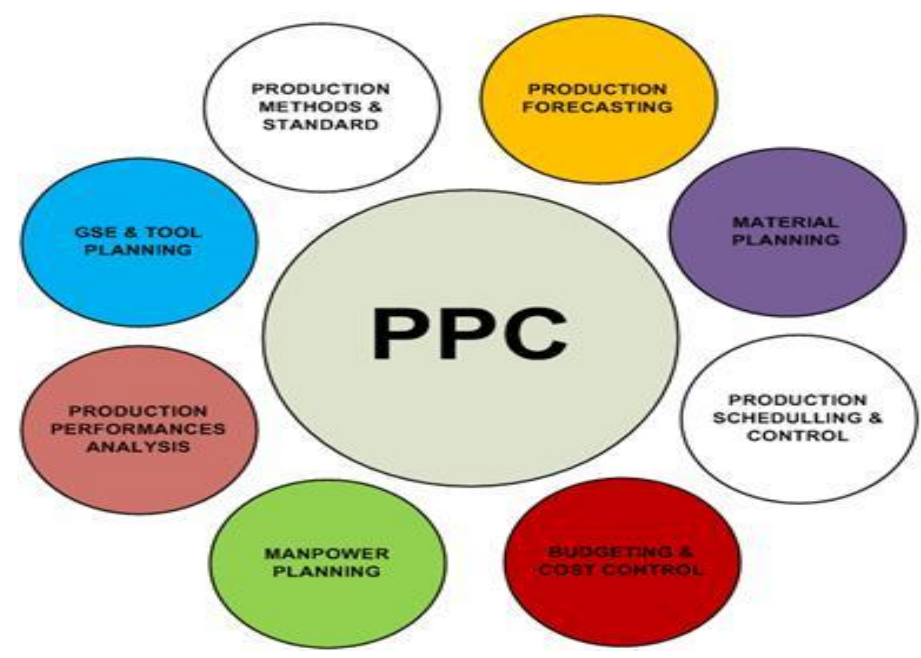

Gambar 5.1 PPC

Sumber https://www.google.co.id/imgres?imgurl=https://3.bp.blogspot.com/-

Proses produksi adalah tahap-tahap yang harus dilewati dalam memproduksi barang atau jasa. Ada proses produksi yang membutuhkan waktu lama, misalnya dalam pembuatan gedung pencakar langit, pembuatan pesawat terbang, dan pembuatan kapal, serta lain-lainnya.

Dalam proses produksi membutuhkan waktu yang berbeda-beda, ada yang sebentar, misalnya pembuatan kain, pembuatan televisi, dan lain-lain. Tetapi, ada juga proses produksi yang dapat dinikmati langsung hasilnya oleh konsumen, misalnya pentas hiburan, pijat, dan produksi lain-lainnya. Berdasarkan caranya, proses produksi digolongkan dalam empat macam yaitu.

\section{a. Proses Produksi Pendek}

Proses produksi yang pendek atau cepat dan langsung menghasilkan barang atau jasa yang dapat dinikmati konsumen. Contohnya adalah proses produksi makanan, seperti pisang goreng, bakwan, singkong goreng, dan lain-lain. 


\section{b. Proses Produksi Panjang}

Proses produksi yang memakan waktu lama. Contohnya adalah proses produksi menanam padi dan membuat rumah.

\section{c. Proses Terus Menerus/Kontinyu}

Proses produksi yang mengolah bahan-bahan secara berurutan dengan beberapa tahap dalam pengerjaan sampai menjadi suatu barang jadi. Jadi bahan tersebut melewati tahap-tahap dari proses mesin secara terus-menerus untuk menjadi suatu barang jadi. Contohnya adalah proses memproduksi gula, kertas, karet, dan lain-lain

\section{d. Proses Produksi Berselingan/Intermitten}

Proses produksi yang mengolah bahan-bahan dengan cara menggabungkannya menjadi barang jadi. Seperti, proses produksi mobil di mana bagian-bagian mobil dibuat secara terpisah, mulai dari kerangkanya, setir, ban, mesin, kaca, dan lain-lain. Setelah semua bagian dari mobil tersebut selesai atau lengkap maka selanjutnya bagian-bagian mobil tersebut digabungkan menjadi mobil.

\section{B. Teori Produksi}

Hoover (1974) dalam Azhar menyatakan bahwa pertumbuhan suatu wilayah merupakan hasil dari interaksi yang kompleks diantara berbagai aktivitas kegiatan ekonomi suatu wilayah, sehingga akan menjadi tidak mungkin untuk menentukan satu penyebab awal dari pertumbuhan wilayah. Perubahan pada perekonomian wilayah bisa bersifat berdiri sendiri (independent), bisa bersifat eksogenous atau bahkan merupakan sebuah kejadian sebab akibat. Akan tetapi, paling tidak Hoover menjelaskan bahwa perubahan pada permintaan (khususnya ekspor suatu wilayah) dan perubahan pada supply tenaga kerja regional serta faktor produksi lainnya (seperti capital atau perubahan teknologi) merupakan penggerak utama dari pertumbuhan suatu wilayah. 
Manyong et al. (2005) menyatakan bahwa kendala yang sangat fundamental terhadap pertumbuhan sektor pertanian adalah sistem produksi, rendahnya respon terhadap pengadopsian teknologi, pemecahan tanah (land fragmentation) dan kegagalan industri rumah tangga dimana meningkat resiko produksi dan boleh jadi disebabkan ketidakjelasan petani-petani bagaimana petani-petani tersebut dapat terlibat dalam melakukan diversifikasi produk atau menghasilkan dengan perusahaan bertingkat dengan cara mengadopsi specific agro-ecological zones(Ajibefun, 2006). Diversifikasi industry rumah tangga sebagai suatu strategi pertanian dipercaya untuk memperoleh sejumlah keuntungan yaitu kemampuan untuk mereduksi resiko, perbaikan pendapatan dan peluang kesempatan kerja, kemampuan untuk mereduksi penyakit danhamadan perbaikan kesuburan tanah (Sing, S., 2000). Bamji, MS., (2000)menyatakan bahwa diversifikasi dalam industry rumah tangga dana/atau antar industry rumah tangga dan perbaikan jaminan nutrisi perternakan, khususnya untuk petani-petani marjinal dan miskin.

Produksi merupakan hasil akhir dari proses atau aktivitas ekonomi dengan memanfaatkan beberapa masukan atau input (Joesron, 2003:77). Dengan pengertian ini dapat dipahami bahwa kegiatan produksi adalah kombinasi berbagai input atau masukan untuk menghasilkan output. Hubungan teknis antara input dan output tersebut dalam bentuk persamaan, tabel atau grafik merupakan fungsi produksi. Sedangkan menurut Salvatore (2007:75) mengemukakan bahwa fungsi produksi adalah hubungan fisik antara variabel yang dijelaskan (Y) dan variabel yang menjelaskan (X). Variabel yang dijelaskan biasanya berupa output dan variabel yang menjelaskan biasanya berupa input. Dengan fungsi produksi, maka peneliti dapat mengetahui hubungan antara faktor produksi (input) dan produksi (output) secara langsung dan hubungan tersebut dapat lebih mudak dimengerti.Selain itu dengan fungsi produksi, maka peneliti dapat mengetahui hubungan antar variabel penjelas. Secara matematis, hubungan ini dapat dijelaskan sebagai berikut (Salvatore, 2007:76)

$$
\mathrm{Y}=\mathrm{f}\left(\mathrm{X}_{1}, \mathrm{X}_{2}, \ldots, \mathrm{X}_{\mathrm{n}}\right)
$$


Fungsi produksi mempunyai sifat-sifat seperti fungsi utility. Jika input bertambah, output juga meningkat. Namun tambahan input pertama akan memberikan tambahan output yang lebih besar dibanding dengan tambahan output yang disebabkan oleh tambahan input berikutnya. Sifat ini disebut law of diminishing return (Case \& Fair, 2007:144).

Mankiw (2006:336) mengatakan bahwa setiap proses produksi mempunyai landasan teknis, yang dalam teori ekonomi disebut fungsi produksi.Fungsi produksi merupakan suatu fungsi atau persamaan yang menunjukkan hubungan antara tingkat output dan tingkat kombinasi penggunaan input-input. Secara grafis, ceteris paribus, fungsi produksi tenaga kerja saja (L) (diasumsikan $\mathrm{K}$ tetap), maka $\mathrm{Q}(\mathrm{L})$ adalah sebagai berikut:

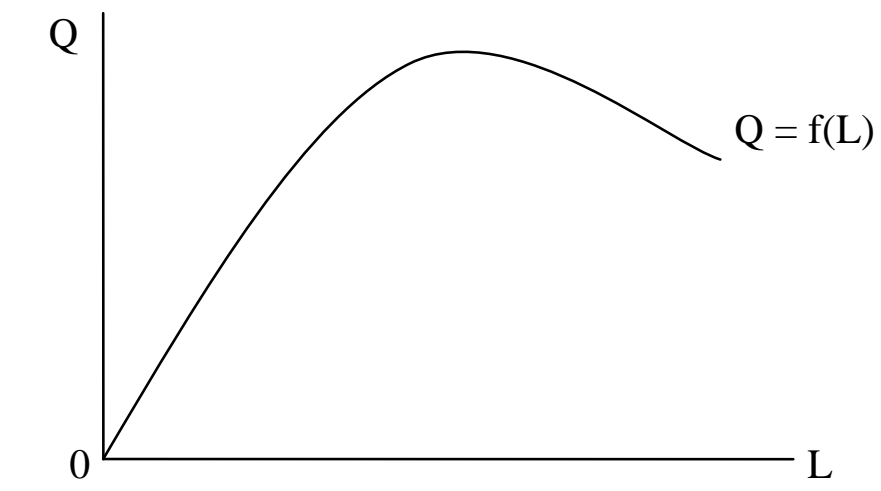

\section{Gambar 1 : Fungsi Produksi}

Sumber: Case \& Fair (2007:144)

Secara matematis, sifat fungsi produksi naik (jika input bertambah maka output bertambah) diindikasikan dengan turunan pertama $Q$ terhadap L adalah positif.Sedangkan sifat kenaikan yang menurun (menggambarkan law of diminishing return) diindikasikan dengan turunan kedua Q terhadap L negatif (kurva concave).Fungsi produksi Cobb-Douglas merupakan suatu fungsi persamaan yang melibatkan dua atau lebih variabel.Variabel yang satu disebut dependent, yang dijelaskan (Y) dan variabel lainnya disebut variabel independent yang menjelaskan (X) (Bilas, 2008:154).penyelesaian hubungan antara X dan Y biasanya dengan cara 
regresi, yaitu variasi dari Y akan dipengaruhi variasi dari X. Adapun fungsi produksi Cobb-Douglas sebagai berikut (Bilas, 2008:154):

$$
\mathrm{Q}=\mathrm{AK} \mathrm{K}^{\alpha} \mathrm{L}^{\beta}
$$

$\mathrm{Q}$ adalah kuantitas output dan $\mathrm{L}$ dan $\mathrm{K}$ masing-masing adalah tenaga kerja dan barang modal $\alpha$ (alpha) dan $\beta$ (betha) adalah parameter-parameter positif yang ditentukan oleh data.

Sifat-sifat fungsi produksi Cobb-Douglas adalah sebagai berikut :

1. $\mathrm{K}$ dan $\mathrm{L}$ bisa saling mensubstitusi

Jika tenaga kerja menjadi mahal, perusahaan akan mensubstitusi tenaga kerja dengan modal. Dalam hal ini, teknologi yang padat karya diganti dengan teknologi padat modal. Sifat substitusi antar input ini mengikuti kaidah Marginal Rate of Technical Substitution/Trasformation yang digambarkan oleh isoquant curve.

2. $\frac{\partial Q}{\partial K}, \frac{\partial Q}{\partial L}>0$, produktivitas marginal dari faktor-faktor produksinya adalah positif. Formula ini menunjukkan produk marjinal modal dan tenaga kerja adalah positif. Marginal Product of Capital (MPP) dan Marginal Product of Labour (MPL) bergantung pada tingkat output dan tingkat penggunaan modal dan tenaga kerja.

$$
M P K=\alpha \frac{Q}{K} \operatorname{dan} M P L=\beta \frac{Q}{L}
$$

3. $\frac{\partial^{2} Q}{\partial K \partial K}, \frac{\partial^{2} Q}{\partial L \partial L},<0$, produktivitas marginal dari faktor-faktor produksinya mengikuti hukum kenaikan yang berkurang (Law of Diminishing Returns). Sifat ini mencerminkan bahwa fungsi produksi Cobb-Douglas bersifak konkaf, implikasinya, fungsi tersebut mempunyai nilai mksimal.

4. $\mathrm{Q}=(\mathrm{K})^{\alpha}(\mathrm{L})^{\beta}$, bersifat :

a) Constant Returns to Scale, jika $(\alpha+\beta)=1$. Artinya, jika input K dan L bertambah masing-masing menjadi dua kalinya, maka outputnya juga 
bertambah dua kali. Dalam hal ini, output bertambah secara proporsional dengan penambahan input.

b) Increasing Returns to Scale, jika $(\alpha+\beta)>1$. Artinya, jika input K dan L ditambah masing-masing menjadi dua kalinya, maka outputnya juga bertambah lebih dari dua kalinya. Dalam hal ini, output bertambah lebih dari proporsi dengan pertambahan input.

c) Decreasing Returns to Scale, jika $(\alpha+\beta)<1$. Artinya, jika input K dan L bertambah masing-masing menjadi dua kalinya, maka outputnya bertambah kurang dari dua kalinya. Output bertambah kurang dari proporsi pertambahan input. Kondisi ini bisa terjadi karena kompleksitas proses produksi menjadi sangat tinggi jika skala operasi mnejadi besar. Decreasing Returns to Scale berimplikasi diseconomics to scale, yaitu biaya rata-rata akan naik sejalan akan kenaikan jumlah output.

Secara grafi atau kurva seperti di bawah ini.

\section{Teori Produksi dengan satu Faktor Produksi}

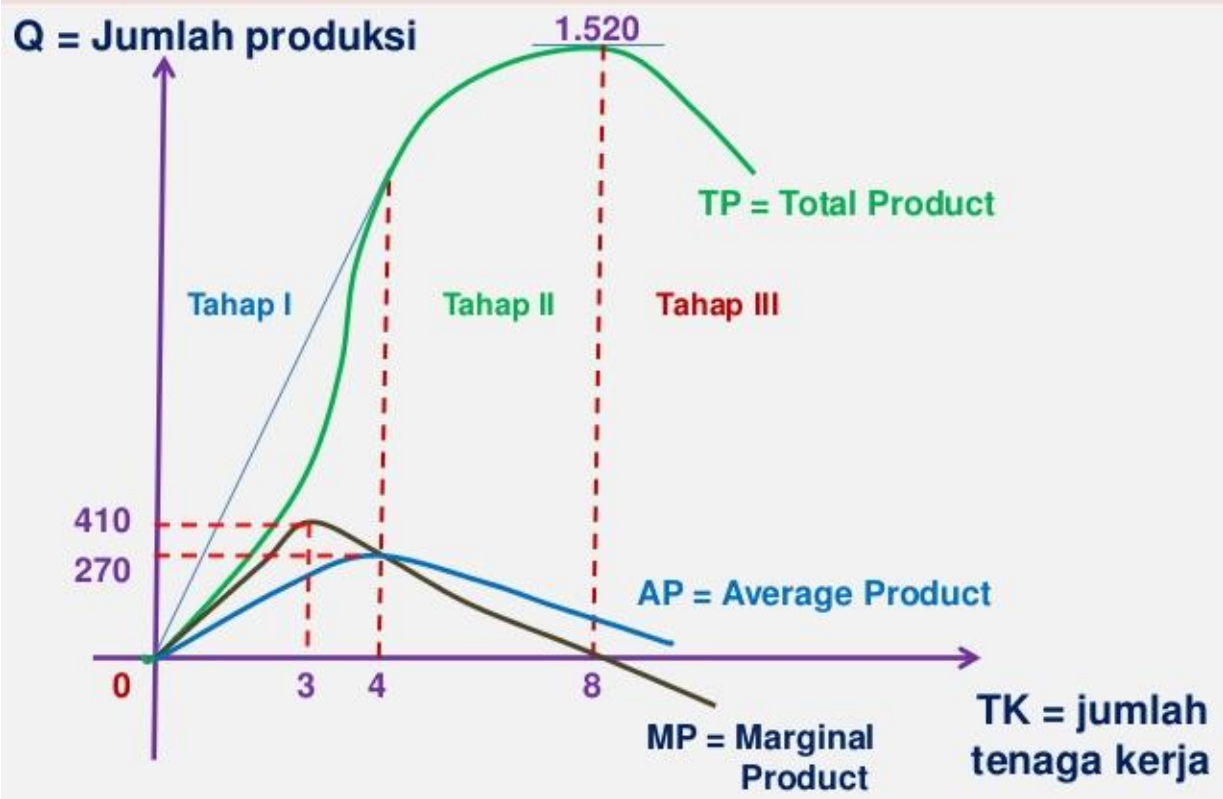




\section{Faktor-Faktor Produksi}

Faktor-Faktor Produksi-Jalan kegiatan produksi tergantung dari tersedianya faktor produksi. Faktor produksi adalah segala sesuatu yang perlukan dalam kegiatan produksi terhadap suatu barang dan jasa. Faktor-faktor produksi terdiri dari alam (natural resources), tenaga kerja (labor), modal (capital), dan keahlian (skill) atau sumber daya pengusaha (enterpreneurship). Faktor-faktor produksi alam dan tenaga kerja adalah faktor produksi utama (asli), sedangkan modal dan tenaga kerja merupakan faktor produksi turunan.

Berikut penjelasan faktor-faktor produksi antara lain;

1. Faktor Produksi Alam, adalah semua kekayaan yang ada di alam semesta digunakan dalam proses produksi. Faktor produksi alam disebut faktor produksi utama atau asli. Faktor produksi alam terdiri dari tanah, air, udara, sinar matahari, dan barang tambang.

2. Faktor Produksi Tenaga Kerja, adalah faktor produksi insani yang secara langsung maupun tidak langsung dapat menjalankan kegiatan produksi. Faktor produksi tenaga kerja sebagai faktor produksi asli. Walaupun kini banyak kegiatan proses produksi diperankan oleh mesin, namun keberadaan manusia wajib diperlukan.

3. Faktor Produksi Modal, adalah faktor penunjang yang mempercepat dan menambah kemampuan dalam memproduksi. Faktor produksi dapat terdiri dari mesin-mesin, sarana pengangkutan, bangunan, dan alat pengangkutan.

4. Faktor Produksi Keahlian, adalah keahlian atau keterampilan individu mengkoordinasikan dan mengelola faktor produksi untuk menghasilkan barang dan jasa.

\section{B. Teori Ongkos}

Ongkos adalah kurva yang menunjukkan saling berhubungan antara jumlah ongkos produksi dengan tingkat output yang dihasilkan. Sedangkan yang dimaksud 
dengan ongkos produksi adalah semua pengeluaran yang dilakukan oleh perusahaan untuk memperoleh faktor-faktor produlsi yang gunanya untuk memproduksi output atau pengeluaran. Ongkos produksi adalah semua pengeluaran yang dilakukan oleh perusahaan untuk memperoleh faktor-faktor untuk memperoleh produksi guna memproduksi output. Dengan kata lain perusahaan harus membayar ongkos produksi tersebut untuk dijual kepada para konsumen-konsumennya.

Macam-macam ongkos diantaranya sebagai berikut :

1) Total Fixed Cost (Onkos Total Tetap)

Total Fixed Cost atau yang disebut juga ongkos total tetap adalah jumlah ongkos yang tetap dan yang tidak dipengaruhi oleh tingkat produksi. Sebagai contohnya adalah sewa, penyusutan dan sebagainya.

\section{2) Total Variabel Cost (Ongkos Variabel Total)}

Total Variabel Cost atau bisa juga disebut ongkos variabel total adalah jumlah ongkos yang dibayarkan yang besarnya berubah menurut tingkah yang dihasilkan. Sebagai contohnya adalah tenaga kerja, ongkos bahan mentah dan sebagainya.

\section{3) Total Cost (Ongkos Total)}

Total Cost atau yang lebih dikenal sebagai Ongkos total adalah penjumlahan antara ongkos total tetap dengan ongkos variabel.

$\mathrm{TC}=\mathrm{TFC}+\mathrm{TVC}$

4) Average Fixed Cost (Ongkos Tetap Rata-rata)

Average Fixed Cost atau bisa juga disebut ongkos tetap rata-rata adalah ongkos tetap yang dibebankan kepada setiap unit output.

$\mathrm{AFN}=\mathrm{TFC}=\mathrm{Q}=$ TINGKAT OUTPUT $\mathrm{Q}$ 


\section{5) Average Fixed Cost (Ongkos Variabel Rata-rata)}

Average Fixed Cost atau yang lebih dikenal sebagai ongkos variabel rata-rata ini adalah ongkos variabel yang dibebankan untuk setiap unit output.

\section{$\mathrm{AVC}=\mathrm{TVC} \mathrm{Q}$}

6) Average Total Cost (Ongkos Total Rata-rata)

Average Total Cost atau bisa juga disebut dengan ongkos total rata-rata adalah suatu ongkos produksi yang dibebankan untuk setiap unit output.

$\mathrm{ATC}=\mathrm{TC} \mathrm{Q}$

\section{7) Marginal Cost (Ongkos Marginal)}

Marginal Ongkos atau bisa juga disebut dengan ongkos marginal yaitu tambahan atau berkurangnya suatu ongkos total karena bertambahnya ataupun berkurangnya suatu unit output.

$\mathrm{MC}=\mathrm{TC}=\mathrm{TVC} \mathrm{Q} \mathrm{Q}$

Ongkos Produksi dapat dibedakan menjadi :

\section{1) Ongkos Produksi Jangka Pendek}

Didalam suatu ongkos produksi jangka pendek sebuah perusahaan sudah mempunyai peralatan-peralatan untuk produksi seperti halnya mesin, gedung dan tanah. Masalah yang perlu diperhatikan didalam ongkos jangka produksi pendek ini adalah bagaimana mengatasi masalah kebijakan bahan baku, tenaga kerja dan sebagainya ini adalah merupakan ongkos variabel. Jadi didalam ongkos produksi jangka pendek ini juga terdapat ongkos tetap dan ongkos variabel.

2) Ongkos Produksi Jangka Panjang

Didalam ongkos produksi janka panjang ini sebuah perusahaan dapat menambah semua faktor produksi, sehingga tidak ada yang namanya ongkos tetap didalam 
ongkos produksi jangka panjang. Semua pengeluaran didalam ongkos jangka panjang ini merupakan ongkos variabel.

\section{Model Sentra Produksi Tomat}

Sentra produksi merupakan unit kecil kawasan yang memilik ciri tertentu dimana didalamnya terdapat kegiatan proses produksi dan merupakan area yang lebih khusus untuk suatu komoditi kegiatan ekonomi yang telah terbentuk secara alami yang ditunjang oleh sarana untuk berkembangnya produk atau jasa yang terdiri dari sekumpulan pengusaha mikro, kecil dan menengah,VARIETAS UNGGUL adalah galur hasil pemuliaan dengan satu atau lebih keunggulan khusus, seperti potensi hasil tinggi, tahan terhadap hama dan penyakit, toleran terhadap cekaman lingkungan, mutu produk tinggi, dan/atau sifat-sifat unggul lainnya, serta telah dilepas pemerintah dan mempunyai ciri tertentu.

\section{Ciri-Ciri Kawasan Sentra Produksi Pangan}

Suatu kawasan sentra produksi pangan yang sudah berkembang harus memiliki ciri-ciri sebagai berikut: Sebagian besar kegiatan masyarakat di kawasan tersebut di dominasi oleh kegiatan pertanian dan atau agribisnis dalam suatu kesisteman yang utuh dan terintegrasi mulai dari:

a) Subsistem agribisnis hulu (up stream agribusiness) yang mencakup: mesin, peralatan pertanian pupuk, dan lain-lain;

b) Subsistem usaha tani/pertanian primer (on farm agribusiness) yang mencakup usaha: tanaman pangan, hortikultura, perkebunan, perikanan, peternakan, dan kehutanan;

c) Subsistem agribisnis hilir (down stream agribusiness) yang meliputi: industriindustri pengolahan dan pemasarannya, termasuk perdagangan untuk kegiatan ekspor; 
d) Subsistem jasa-jasa penunjang (kegiatan yang menyediakan jasa bagi agribisnis) seperti: perkreditan, asuransi, transportasi, penelitian dan pengembangan, pendidikan, penyuluhan, infrastruktur, dan kebijakan pemerintah.

e) Adanya keterkaitan antara kota dengan desa (urban-rural linkages) yang bersifat interdependensi/timbal balik dan saling membutuhkan, dimana kawasan pertanian di perdesaan mengembangkan usaha budi daya (on farm) dan produk olahan skala rumah tangga (off farm), sebaliknya kota menyediakan fasilitas untuk berkembangnya usaha budi daya dan agribisnis seperti penyediaan sarana pertanian antara lain: modal, teknologi, informasi, peralatan pertanian dan lain sebagainya;

f) Kegiatan sebagian besar masyarakat di kawasan tersebut didominasi oleh kegiatan pertanian atau agribisnis, termasuk didalamnya usaha industri (pengolahan) pertanian, perdagangan hasil-hasil pertanian (termasuk perdagangan untuk kegiatan ekspor), perdagangan agribisnis hulu (sarana pertanian dan permodalan), agrowisata dan jasa pelayanan;

g) Kehidupan masyarakat di kawasan sentra produksi pangan (agropolitan) sama dengan suasana kehidupan di perkotaan, karena prasaranaa dan infrastruktur yang ada dikawasan agropolitan diusahakan tidak jauh berbeda dengan di kota.

\section{Persyaratan Kawasan Sentra Produksi Pangan}

Suatu wilayah dapat dikembangkan menjadi suatu kawasan sentra produksi pangan (agropolitan) harus dapat memenuhi persyaratan sebagai berikut:

a) Memiliki sumberdaya lahan dengan agroklimat yang sesuai untuk mengembangkan komoditi pertanian khususnya pangan, yang dapat dipasarkan atau telah mempunyai pasar (selanjutnya disebut komoditi unggulan);

b) Memiliki prasarana dan infrastruktur yang memadai untuk mendukung pengembangan sistem dan usaha agribisnis khususnya pangan, seperti misalnya: 
jalan, sarana irigasi/pengairan, sumber air baku, pasar, terminal, jaringan telekomunikasi, fasilitas perbankan, pusat informasi pengembangan agribisnis, sarana produksi pengolahan hasil pertanian, dan fasilitas umum serta fasilitas sosial lainnya;

c) Memiliki sumberdaya manusia yang mau dan berpotensi untuk mengembangkan kawasan sentra produksi pangan (agropolitan) secara mandiri;

d) Konservasi alam dan kelestarian lingkungan hidup bagi kelestarian sumberdaya alam, kelestarian sosial budaya maupun ekosistem secara keseluruhan.

\section{Sistem Kawasan}

Kawasan Sentra produksi pangan bisa terdiri atas:

a) Kawasan lahan pertanian (hinterland)

Berupa kawasan pengolahan dan kegiatan pertanian yang mencakup kegiatan pembenihan, budidaya dan pengelolaan pertanian. Penentuan hinterland berupa kecamatan/desa didasarkan atas jarak capai/radius keterikatan dan ketergantungan kecamatan/desa tersebut pada kawasan sentra produksi pangan (agropolitan) di bidang ekonomi dan pelayanan lainnya.

b) Kawasan pemukiman

Merupakan kawasan tempat bermukimnya para petani dan penduduk kawasan sentra produksi pangan.

c) Kawasan pengolahan dan industri

Merupakan kawasan tempat penyeleksian dan pengolahan hasil pertanian sebelum dipasarkan dan dikirim ke terminal agribisnis atau pasar, atau diperdagangkan. Dikawasan ini bisa berdiri pergudangan dan industri yang mengolah langsung hasil pertanian menjadi produk jadi.

d) Kawasan pusat prasarana dan pelayanan umum Yang terdiri dari pasar, kawasan perdagangan, lembaga keuangan, terminal agribisnis dan pusat pelayanan umum lainnya. 
e) Keterkaitan antara kawasan sentra produksi pangan dengan kawasan lainnya, misalnya; kawasan permukiman, kawasan industri, dan kawasan konservasi alam.

\section{Cakupan Wilayah}

Suatu wilayah atau kawasan sentra produksi pangan (agropolitan) bisa dipetakan berdasarkan potensi sektor unggulan suatu usaha pertanian dari wilayah tersebut. Cakupan wilayah kawasan sentra produksi pangan (agropolitan) terbagi atas tipologi pertanian:
a. Sektor usaha pertanian tanaman pangan; Tanaman Tomat
b. Sektor usaha pertanian hortikultura;
c. Sektor usaha perkebunan; Tanaman Aren
d. Sektor usaha peternakan;
e. Sektor usaha perikanan darat;
f. Sektor usaha perikanan laut;
g. Sektor usaha agrowisata;
h. kawasan hutan wisata konservasi alam.

Di bawah ini dibuatkan contoh hasil penelitian Tomat Bukit Sileh Kabuoaten Solok 2017 dengan peta pikir seperti gambar di abawah ini. 


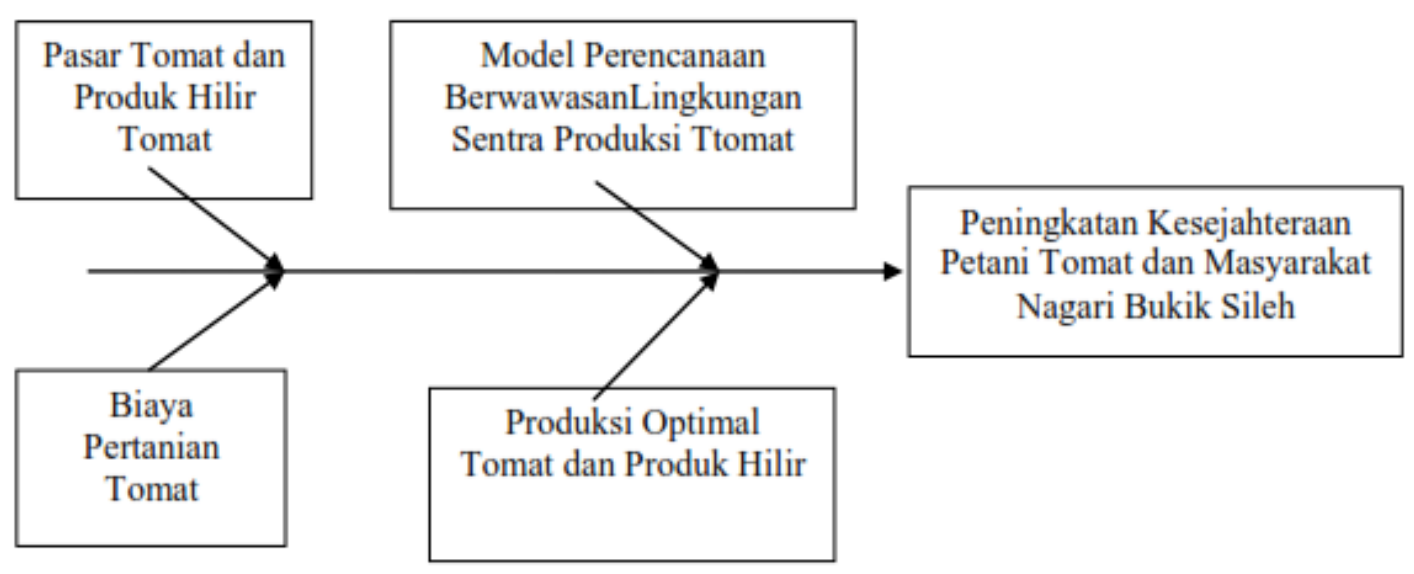

Permasalahan yang terjadi adalah disaat produksi tomat berlebih dari produksisinya, maka harga tomat semakin rendah dan biaya yang dikeluarkan petani tidak menguntungkan seperti mengalami kerugian. Jika tomat saat panen raya tomat tidak habis terjuan dan bahkan buah tomat tidak diambil oleh petani karena terjadi demotivasi. Jika diambiltomat yang kecil-kecil serta yang kualitas kurang terbuang begitu saja dan bahkan mencemari lingkungan yang berbau busuk dan muncul lalat.

Dari pemkiran itu munculah ide membuat sentra tomat dengan tujuan tidak ada muncul masalah disaat tomat panen raya atau tidak ada pasarnya. Sehingga dibuatkan sentra produksi tomat dengan usaha yang berinput berbasis tomat.Dengan demikian petani fokus berproduksi dan jaminan pasar sudah ada.

\section{Deskripsi Model Sentra Hilirisasi Produksi Tomat:}

Deskripsi : Model Sentra Hilirisasi Produksi Tomat ini dikembangkan oleh Drs. Zul Azhar, M.Si dan Prof. Dr. Hasdi Aimon, M.Si; Fakultas Ekonomi Universitas Negeri Padang. Model ini bertujuan sebagai acuan dalam optimalisasi tata guna lahan, memanfaatkan hasil produksi tomat secara efektif dan efisiensi penggunaan hasil pertanian yang berwawasan lingkungan, sehingga daerah sentra penghasil tomat dapat meningkatkan 
hasil pertanian sekaligus dapat menghasilkan produk-produk berbasis tomat dengan tetap memperhatikan faktor lingkungan. Produk berbasis tomat yang dikembangkan berdasarkan model ini dapat menunjang program pembangunan nagari (atau sektor wilayah secara luas) yang berkelanjutan (sustainable development). Model Sentra Hilirisasi Produksi Tomat ini telah melalui serangkaian penelitian secara mendalam dan uji coba selama satu tahun (2017) dengan menghasilkan data bahwa model ini dapat meningkatkan produksi pertanian tomat dan produksi lainnya berbahan dasar tomat dengan efektif dan efisien dengan tetap memperhatikan faktor lingkungan.

Novelty/ Applicable : Model Sentra Hilirisasi Produksi Tomat ini merupakan model hilirisasi produksi pertanian yang baru dan relevan dengan kondisi yang saat ini terjadi di lapangan. Beberapa model hilirisasi dan pemanfaatan hasil produksi pertanian sebelumnya belum cukup mumpuni dalam menjawab tantangan di lapangan. Nilai kebaruan dari model ini adalah adanya kajian mendalam mengenai kondisi produksi tomat secara umum, biaya pengadaan bibit oleh petani, pupuk, luas lahan, unit usaha pengolahan produk, pasar penampung dari produk, dan faktor-faktor eksternal lainnya. Model ini telah memenuhi persyaratan standar ilmiah dalam pengembangan dan validasi model, sehingga dapat dimanfaatkan oleh pengguna; antara lain oleh petani dalam menentukan pasar jika produksi tomat melimpah, oleh unit usaha pengolahan tomat maupun oleh pengambil kebijakan dalam optimalisasi pembangunan perekonomian dan nagari yang berkelanjutan (sustainable development) 


\section{Model Sentra Hilirisasi Produksi Tomat}

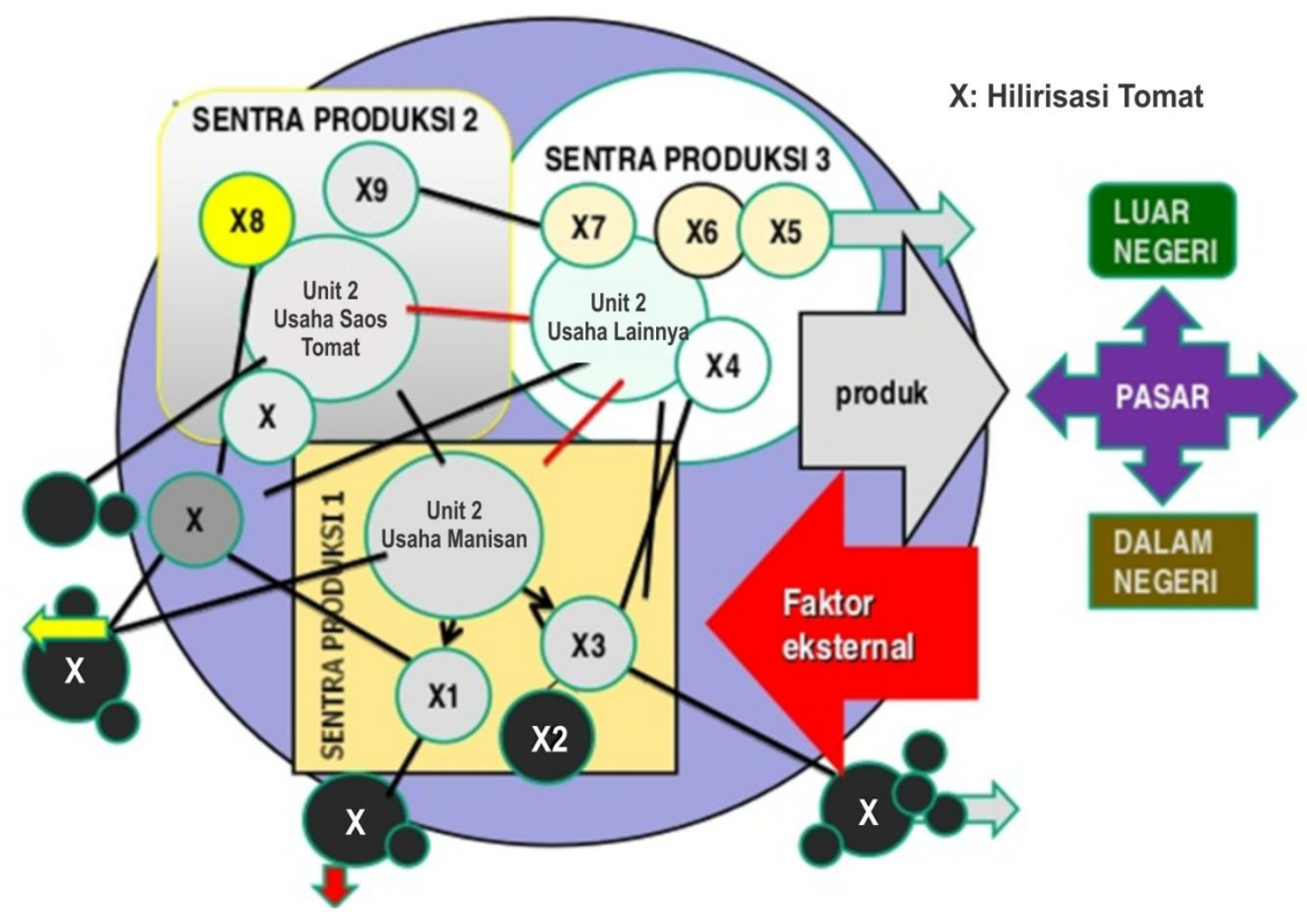




\section{BAB VI \\ EKONOMI LINGKUNGAN}

\section{A. Pengertian Ekonomi Lingkungan}

Ekonomi adalah kajian tentang bagaimana dan mengapa individu dan kelompok membuat keputusan tentang penggunaan dan distribusi sumber daya berharga manusia dan bukan manusia. Hal ini tidak semata-mata studi tentang keuntungan bisnis membuat keputusan dalam ekonomi kapitalis. Hal ini jauh lebih luas dari ini; ia menyediakan satu set alat analisis yang dapat digunakan untuk mempelajari situasi di mana kelangkaan sarana membutuhkan keseimbangan tujuan bersaing. Ini termasuk, misalnya, pertanyaan dalam perilaku organisasi nirlaba, lembaga pemerintah, dan konsumen.

Ekonomi Lingkungan adalah penerapan prinsip-prinsip ekonomi untuk mempelajari bagaimana sumber daya lingkungan dikelola. Ekonomi dibagi menjadi ekonomi mikro, studi tentang perilaku individu dan kelompok-kelompok kecil dan makroekonomi, studi mengenai kinerja ekonomi secara keseluruhan. ekonomi lingkungan menarik dari kedua belah pihak, meskipun lebih dari mikroekonomi daripada dari pada macroekonomi. Ini berfokus terutama pada bagaimana dan mengapa orang membuat keputusan yang memiliki konsekuensi bagi lingkungan alam. Hal ini berkaitan juga dengan bagaimana lembaga-lembaga dan kebijakan ekonomi dapat diubah untuk membawa dampak mental yang environment ini lebih ke dalam keseimbangan dengan keinginan manusia dan kebutuhan ekosistem itu sendiri. Ekonomi lingkungan adalah subjek analisis, hal ini tidak hanya untuk menggambarkan keadaan lingkungan dan perubahan di dalamnya, tetapi juga untuk memahami mengapa kondisi ini ada dan bagaimana bisa membawa perbaikan dalam kualitas lingkungan.

Jadi Ekonomi lingkungan adalah ilmu yang mempelajari kegiatan manusia

dalam memanfaatkan lingkungan sedemikian rupa sehingga fungsi/peranan 
lingkungan dapat dipertahankan atau bahkan dapat ditingkatkan dalam penggunaannya untuk jangka panjang.

\section{B. Penyebab Merosotnya Fungsi Lingkungan}

Fungsi atau peranan lingkungan menjadi merosot disebabkan karena sifat atau ciri yang melekat pada lingkungan itu sendiri sehingga menyebabkan manusia mengeksploitasinya secara berlebihan melebihi daya dukung lingkungan tersebut. Beberapa ciri atau sifat yang menonjol dan melekat pada lingkungan adalah; adanya ciri atau sifat sebagai barang public, adanya sifat atau ciri sebagai barang milik bersama (common property) dan adanya ciri atau sifat eksternalitas.

a. Barang Publik

Dengan adanya sifat ini telah membawa konsekuensi terhadap terbangkalainya sumber daya lingkungan, karena tidak akan ada atau langkanya pihak swasta atau individu yang mau memelihara atau melestarikan sumberdaya lingkungan.

b. Pemilikan bersama/ milik umum

Pemilikan bersama dapat diartikan sebagai bukan milik seseorang namun milik semua orang (common property is no one property and is every one property). Denga pemilikan seperti ini akan membuat kecenderungan untuk mengeksploitasi sumber daya alam dan lingkungan melebihi daya dukung alam tersebut. Setiap orang akan merasa harus mengambil atau mengusahakan terlebih dahulu sebelum orang lain. Contohnya penambangan emas, dll.

a. Eksternalitas

Hal ini muncul apabila seseorang melakukan kegiatan dan menimbulkan tidak memerlukan kewajiban untuk menerima atau melakukan pembayaran. 


\section{Kebijakan Pemerintah}

Kebijakan pemerintah yang perlu diambil dan sudah dilaksanakan pemerintah Indonesia dalam kaitannya dengan pengelolaan sumber daya alam dan lingkungan agar fungsi lingkungan dapat tetap lestari adalah:

a. Memperbaiki hak penguasaan atas sumber daya alam dan lingkungan (property right) dari "common property" menjadi "private property". Dengan adanya private property, barang public dapat diubah sifatnya menjadi barang privat, sehingga akan cenderung dipelihara dengan baik.

b. Memperbaiki sumber daya alam dan lingkungan sehingga biaya eksternal dapat diinternalkan dengan cara menerapkan command and control sytem dan atau dengan economic incentive system termasuk polluter pays principle. Untuk itu perlu disiapkan Analisis Mengenai Dampak Lingkungan (AMDAL), Rencana Kelola Lingkungan (RKL), Rencana Pemantauan Lingkungan (RPL) untuk setiap proyek atau kegiatan yang memberikan dampak besar bagi lingkungan.

c. Menggunakan tekanan social untuk mengurangi pencemaran seperti dengan system ecolabeling. Pemerintah menggunakan kekuatan para konsumen untuk menekan produsen agar mau memproduksi produk yang bersahabat dengan lingkungan sejak awal pengambilan input sampai dengan konsumsi akhir.

d. Memberikan insentif untuk pengelolaan lingkungan yang baik melalui penghargaan atau perlombaan seperti Program Kalpataru, Adipura dll.

\section{Lingkungan Sebagai Sumber Bahan Mentah}

\section{a Sumber daya air minum,}

Kota-kota besar di Indonesia volume air telah menurun, juga terjadi intrusi air laut dengan jarak yang semakin jauh ke daratan. Untuk kota Jakarta misalnya, dimana kebutuhan air minum dipasok oleh PDAM yang nengolah air kali Ciliwung menjadi air minum tampak mengalami banyak kesulitan.

\section{b Sumber daya tanah}


Sumber daya ini bukan saja sebagai hal yang sangat vital untuk sector pertanian tetapi juga sangat vital untuk sector yang lain seperti perumahan, perkotaan, industri, jalan, dll.

\section{c Sumber daya Perikanan dan Kelautan}

Meskipun tampaknya produksi ikan secara statistic meningkat dari tahun ke tahun namun usaha penagkapannya semakin sulit. Para pelaut harus menempuh jarak yang semakin jauh dari pantai, alasannya karena rusaknya terumbu karang sebagai akibat dari cara penangkapan ikan salah. Demikian pula dengan hutan mangrove yang juga mengalami penyusutan dalam luasnya., padahal hutan mangrove telah menjadi sumber kehidupan masyarakat pesisir pantai sebab dapat memberikan berbagai macam fungsi seperti, kayunya dapat untuk bahan bengunan sederhana, tempat pembenihan udang-udang dan ikan kecil.

\section{Dampak Pencemaran Terhadap Produktivitas}

Pencemaran lingkungan akan sangat terasa dampaknya pada ketidaknyamanan kehidupan manusia baik secara langsung maupun tidak langsung. Memburuknya kualitas air yaitu bila air tercemar zat-zat logam berat dan beracun sehingga menyebabkan air tidak cocok bagi peruntukkannya dan akan menimbulkan dampak bagi manusia, hewan maupun biota. Misalnya tanah dan air tercemar merkuri, hal ini dapat mengakibatkan gangguan kesehatan pada masyarakat yang terpapar zat pencemar tersebut. Gangguan kesehatan dapat berupa pusing-pusing, mual-mual, anak lahir cacat bawaan, penyakit kulit, retardasi mental, dll. Bukan hanya itu, zat beracun tersebut dapat merusak lahan pertanian sehingga lahan menjadi menurun kualitasnya yang mengakibatkan turunnya produktivitas lahan yang dimaksud. 


\section{Lingkungan Dan Pembangunan Berkelanjutan (Sustainable Development)}

\section{a Tiga Pilar Pembangunan Berkelanjutan}

Pembangunan berkelanjutan diartikan sebagai pembangunan yang tidak ada henti-hentinya dengan tingkat hidup generasi yang akan datang lebih baik dari sekarang. Keberlanjutan pembangunan dapat diartikan bahwa generasi yang akan datang harus berada pada posisi yang tidak lebih buruk daripada generasi sekarang. Generasi sekarang boleh saja melakukan eksploitasi terhadap sumberdaya alam, namun harus tetap menjaga keberadaannya, sedangkan generasi mendatang meskipun memiliki jumlah sumberdaya alam yang mungkin lebih sedikit tetapi memiliki tingkat teknologi dan pengetahuan yang lebih baik. Intinya, generasi akan datang tidak kurang sejahtera dibandingkan generasi sekarang. Menurut Sumarwoto,2006, pengertian pembangunan berkelanjutan adalah: perubahan positif social ekonomi yang tidak mengabaikan system ekologi dan social dimana masyarakat bergantung padanya. Keberhasilan penerapannya memerlukan kebijakan, perencanaan dan proses pembelajaran social yang terpadu, viabilitas politiknya tergantung pada dukungan penuh masyarakat melalui pemerintahannya, kelembagaan sosialnya, dan kegiatan dunia usahanya.Tiga pilar pembangunan berkelanjutan sejak Deklarasi Stockholm 1972 menuju Rio de Janeiro 1992, sampai dengan Rio + 10 di Johanesburg 2002 ditekankan perlunya koordinasi dan integrasi sumberdaya alam, sumberdaya manusia dan sumberdaya buatan dalam setiap pembangunan nasional dengan pendekatan kependudukan, pembangunan dan lingkungan sampai dengan integrasi aspek social, ekonomi, dan lingkungan yang menjadi pertimbangan sekarang adalah bagaimana pelaksanaan untuk diintegrasikan ketiga pilar tersebut.

b Dimensi Manusia Sebagai Subjek dan Objek Pembangunan Sosial Ekonomi

Proses pembangunan seharusnya menempatkan manusia sebagai subyek sekaligus obyek pembangunan itu (Misra,1991). Manusia merupakan subyek 
pembangunan karena ia merupakan pelaksana pembangunan. Manusia menjadi obyek pembangunan, sebab sasaran hasil pembangunan pada hakikatnya untuk kepentingan manusia itu sendiri. Pembangunan dilaksanakan oleh dan untuk manusia, oleh karenanya aspek kesejahteraan yang adil dan merata di setiap wilayah harus diupayakan manusia sebagai individu.

Setiap orang mempunyai hak untuk berperan dalam pengelolaan lingkungan hidup, sesuai dengan perundang-undangan yang berlaku. Berikutnya mengenai peran masyarakat dalam pengelolaan lingkungan hidup beserta cara pelaksanaannya diatur dalam pasal 7 yakni masyarakat mempunyai kesempatan yang sama dan seluas-luasnya untuk berperan dalam pengelolaan lingkungan hidup. Pelaksanaan hal tersebut dilakukan dengan cara:

a. Meningkatkan kemandirian, keberdayaan masyarakat, dan kemitraan.

b. Menumbuhkembangkan kemapuan dan kepeloporan masyarakat.

c. Menumbuhkan ketanggapan masyarakat untuk melakukan pengawasan social.

d. Memberikan saran pendapat

e. Menyampaikan informasi dan/atau menyampaikan laporan.

\section{Kegagalan Perencanaan Pemerintah}

Meskipun sudah ada alasan bahwa sebaiknya pemerintah campur tangan dalam hal eksternalitas, nemun kenyataannya kemampuan pemerintah seringkali tidak lebih baik daripada swasta dalam mengelola lingkungan Hal ini karena ada faktor penyebab kegagalan pemerintah antara lain;

1) adanya kelompok penekan

Alasan utama pemerintah gagal dalam bertindak dan berpikir untuk melindungi kepentingan masyarakat, karena kenyataannya pemerintah justru sering kali melindungi kepentingan individu. Pemerintah sering bertindak demi kepentingan kelompok atau golongan tertentu lebih-lebih jika memasuki 
ranah politik, sehingga keputusan pemerintah akan berpihak pada golongan tertentu saja. Jadi bukan kepentinga secara umum yang dilindungi namun kepentingan golongan masyarakat yang berpengaruh karena politik maupun financial yang sering kali disebut sebagai kelompok penekan (pressure group)

2) Kurang informasi

Pemerintah seringkali kurang memiliki informasi yang akurat dibandingkan dengan pihak individu atau swasta, sehingga pemerintah kurang memahami dampak dari setiap tindakan atau kebijakan yang ditempuh. Oleh karena itu, seringkali apa yang dimaksudkan atau dituju pemerintah tidak tercapai karena kompleksnya permasalahan dan kurangnya informasi yang dikuasai.

3) Kurangnya minat para birokrat

Walaupun pemerintah yang terdiri atas politisi telah membentuk peraturan perundang-undangan intuk melindungi lingkungan, tetapi semua itu diterjemahkan ke dalam praktek dan pelaksanaan. Pemerintah mengangkat tenaga ahli untuk menerapkan peraturan, namun terkadang para ahli yang akhirnya menjadi bagian dari birokrat menjadi sangat penting dan dapat mempengaruhi pelaksanaan peraturan yang bersangkutan. Akibatnya birokrat bertindak tidak demi kepentingan masyarakat, tetapi demi kepentingan kelompok.

\section{Beberapa contoh kegagalan pemerintah}

a) Kebijakan pembangunan pertanian

Sejak PELITA I tahun 1967/68 Indonesia telah bertekad mengutamakan pembangunan ekonomi yang bertumpu pada pembangunan pertanian. Hal didasari karena pangan merupakan dasar begi kestabilan ekonomi dan politik, yang selanjutnya merupakan landasan bagi pembangunan secara keseluruhan. Pengalaman inflasi yang deras pada tahun 1960-an dan dampak krisis ekonomi tahun 1997/98 tetap menempatkan beras sebagai barometer ekonomi, sehingga peran swasembada 
pangan sangat penting. Untuk itu diadakan BIMAS dan system panca usaha tani yang terbukti telah berhasil meningkatkan produksi beras di Indonesia.

Kedua program tersebut telah membimbing masyarakat petani secara intensif menggunakan pupuk dan insektisida agar prduksi pertanian padi meningkat, namun, di sisi lain pemerintah menggunakan kebijakan harga negative (negative rice price policy) yang diartikan sebagai kebijakan menekan harga padi, sehingga harga padi bukan merupakan insentif bagi petani untuk meningkatkan produksinya. Harga padi justru ditekan rendah dengan maksud agar harga beras dapat dijangkau masyarakat luas terutama buruh-buruh atau tenaga kerja di sector industri perkotaaan, para mahasiswa dan pekerja pada umumnya. Hal ini memang sangat diperlukan untuk menjamin ketenangan kerja mereka, sehingga suhu politik dapat dipertahankan stabil. Dengan menggunakan kebijakan cadangan (buffer stock policy), BULOG berusaha mempertahankan harga beras stabil dengan menentukan harga atas dan harga dasar beras.

Hal ini merupakan salah satu kegagalan pemerintah karena pemerintah ternyata melindungi konsumen dari kenaikan harga beras namun mengorbankan petani dengan memberikan harga beras yang terlalu rendah dibandingkan dengan harga pasar. Akibatnya permintaan pasar akan beras meningkat, bahkan pangan nonberas seperti sagu, ketela, ubi, tales dll digantikan dengan beras sebagai makanan pokok. Bagaimana dampaknya terhadap lingkungan? Jelas yang terjadi apabila produksi berlebihan dan penggunaan lahan pertanian yang sangat intensif dapat menimbulkan hama wereng yang mengakibatkan kegagalan panen, seperti peristiwa tahun 1970-an. Sumberdaya air menjadi tercemar oleh pupuk dan insektisida, sehingga tidak hanya mengganggu kehidupan satwa air, tetapi juga manusia.

Dampak keseluruhan dari kebijakan pembangunan pertanian adalah:

a. Pemerintah menggunakan pajak dan sumber pendapatan lain untuk membiayai subsidi pangan melalui kebijakan harga pangan, sehingga kebijakan ini telah mengurangi tersedianya dana untuk pembangunan lainnya. 
b. Subsidi mendorong penggunaan SDA yang mendapatkan subsidi. Dalam hal pertanian penggunaan tanah akan sangat intensif dibarengi dengan penggunaan insektisida dan pupuk buatan yang berlebihan.

c. Timbul inefficiency dalam alokasi factor produksi. Sector kegiatan yang mendapat subsidi menjadi sangat menarik karena tingginya tingkat keuntungan yang sebetulnya merupakan hal semu sehingga alokasi factor produksi menjadi tidak tepat.

b) Harga air irigasi

Pembangunan sarana irigasi sangat penting dalam pengembangan produksi sector pertanian. Air irigasi memiliki banyak fungsi, selain dibutuhkan disektor pertanian tetapi juga untuk kepentingan sector industri, listrik dan perkotaan. Selama ini penggunaan air di sector pertanian dimaksudkan untuk mendorong penigkatan hasil produksi pertanian (padi). Oleh karena itu, di Indonesia petani tidak diwajibkan membayar air irigasi. Dengan kebijakan ini, maka petani leluasa menggunakan air tanpa memperhatikan volume air yanag digunakan. Akibatnya terjadi pemborosan penggunaan sumberdaya air. Di sisi lain air yang digunakan untuk listrik perkotaan menjadi kurang tersedia sehingga harganya menjadi mahal.

c) Kebijakan harga energi

Sumber energi seperti bahan bakar minyak, batu bara, gas dan listrik seringkali mendapat subsidi yang sangat besar di Negara-negara berkembang termasuk Indonesia. Dengan subsidi BBM mendorong penggunaan BBM berlebihan sehingga mencemari lingkungan. Dampak ekonomi dari subsidi BBM jelas merupakan kebocoran yang sangat tinggi dari dana pemerintah dalam pembangunan. Akibatnya menumpuknya hutang pemerintah dan swasta karena terpaksa meminjam dari luar negeri untuk membiayai pembangunan Indonesia. 


\section{Nilai Ekonomi Total}

Sumber daya dalam konteks ini adalah hutan. David dan Johnson ( 1987 ) mengklasifikasi nilai berdasarkan cara penilaian atau penentuan besar nilai dilakukan, yaitu : (a) nilai pasar, yaitu nilai yang ditetapkan melalui transaksi pasar, (b) nilai kegunaan, yaitu nilai yang diperoleh dari penggunaan sumber daya tersebut oleh individu tertentu, dan (c) nilai sosial, yaitu nilai yang ditetapkan melalui peraturan, hukum, ataupun perwakilan masyarakat. Sedangkan Pearce (1992) dalam Munasinghe membuat klasifikasi nilai manfaat yang menggambarkan Nilai Ekonomi Total (Total Economic Value) berdasarkan cara atau proses manfaat tersebut diperoleh.

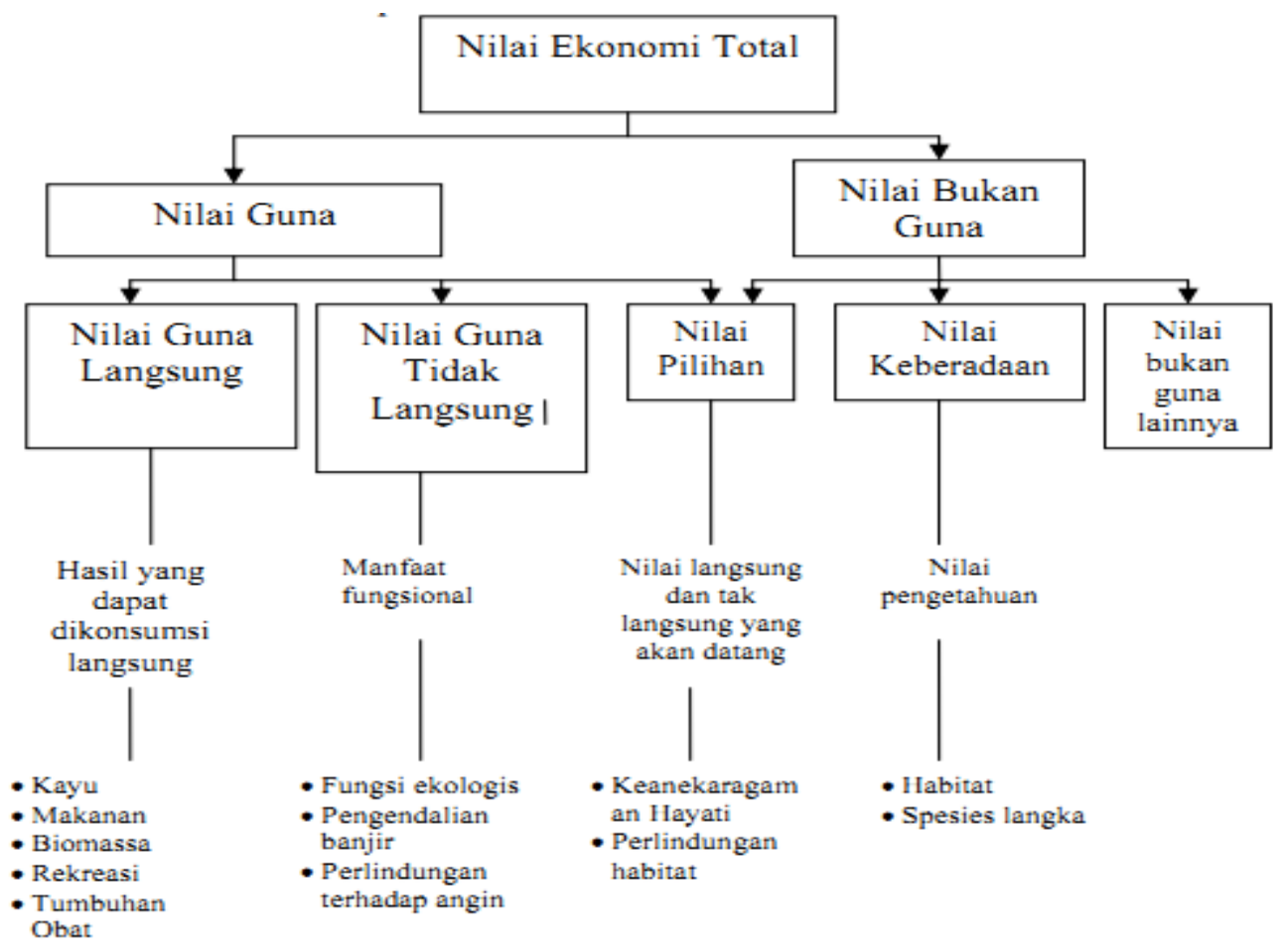

Gambar 1. Nilai ekonomi total dari sumberdaya hutan (Pearce, 1992 dalam Munasinghe 1993).

Nilai ekonomi total ( NET ) merupakan penjumlahan dari nilai guna langsung, nilai guna tidak langsung, dan nilai non guna, dengan formulasi sebagai berikut ( Pearce, 1992 ) : 


\section{NET = Nilai Guna Langsung + Nilai Guna Tidak Langsung + Nilai Pilihan + Nilai Keberadaan.}

Jadi Nilai ekonomi total adalah nilai-nilai ekonomi yang terkandung dalam suatu sumber daya alam (Misalnya Tanaman Pohon Aren dan sebagainya), baik nilai guna maupun nilai fungsional yang harus diperhitungkan dalam menyusun kebijakan pengelolaannya sehingga alokasi dan alternative penggunaannya dapat ditentukan secara benar dan mengenai sasaran. Atau nilai ekonomi total itu bagaimana proses terjadinya nilai ekonomi total (NET) itu sendiri yang terdiri dari nilai guna dan nilai bukan guna. Karena pada dasarnya nilai itulah sebagai acuan dalam pengelolaan sumber daya yang beralokasi serta memiliki sistem alternatif dalam penggunaan yang ditentukan secara benar dan sesuai sasaran

NET atau Total Economic Value (TEV) dapat ditulis dalam persamaan matematis sebagai berikut (CSERGE, 1994 dalam Irmadi, 2004 ) :

$$
\begin{aligned}
& \mathrm{TEV}=\mathrm{UV}+\mathrm{NUV} \\
& \mathrm{UV}=\mathrm{DUV}+\mathrm{IUV}+\mathrm{OV} \\
& \mathrm{NUV}=\mathrm{BV}+\mathrm{EV}
\end{aligned}
$$

Dimana :

$$
\mathrm{TEV}=\mathrm{UV}+\mathrm{NUV}=(\mathrm{DUV}+\mathrm{IUV}+\mathrm{OV})+(\mathrm{BV}+\mathrm{EV})
$$

$\mathrm{TEV}=$ Total Economic Value ( Nilai Ekonomi Total )

$\mathrm{UV}=$ Use Values ( Nilai Manfaat)

NUV = Non-Use Value ( Nilai Bukan Manfaat $)$

DUV = Direct Use Value ( Nilai Kegunaan Langsung )

IUV = Indirect Use Value ( Nilai Kegunaan Tidak Langsung )

$\mathrm{OV}=$ Option Value ( Nilai Pilihan )

$\mathrm{EV}=$ Eksistence Value (Nilai Keberadaan)

$\mathrm{BV}=$ Bequest Value ( Nilai Warisan/Kebanggaan ) 
Direct Use Value ( Nilai Kegunaan Langsung ) yaitu output ( barang dan jasa) yang terkandung dalam suatu sumber daya (Aren) yang secara langsung dapat dimanfaatkan.Nilai guna langsung merupakan nilai dari manfaat yang langsung dapat diambil dari sumber daya. Sebagai contoh manfaat penggunaan sumber daya sebagai input untuk proses produksi atau sebagai konsumsi.

Berbeda dengan nilai guna tidak langsung,

Indirect Use Value ( Nilai Kegunaan Tidak Langsung ) yaitu barang dan jasa yang ada karena keberadaan suatu sumber daya yang tidak secara langsung dapat diambil dari sumber daya alam tersebut, seperti berbagai manfaat yang bersifat fungsional yaitu berbagai manfaat ekologis sumber daya.

Nilai pilihan, mengacu kepada nilai penggunaan langsung dan tidak langsung yang berpotensi dihasilkan dimasa yang akan datang. Hal ini meliputi manfaatmanfaat sumber daya alam yang "disimpan atau dipertahankan" untuk kepentingan yang akan datang ( sumber daya yang disisihkan untuk panen yang akan datang), apabila terdapat ketidakpastian akan ketersediaan sumber daya tersebut, untuk pemanfaatan yang akan datang. Contoh lainnya adalah sumber daya genetic dari hutan tropis untuk kepentingan masa depan.

Sedangkan Nilai guna yaitu semua manfaat yang dihasilkan bukan dari hasil interaksi secara fisik antara sumber daya dan konsumen( pengguna ).

Nilai bukan guna meliputi manfaat yang tidak dapat diukur yang diturunkan dari keberadaan sumber daya di luar nilai guna langsung dan tidak langsung. Nilai bukan guna terdiri atas nilai keberadaan dan nilai warisan.

1. Nilai keberadaan adalah nilai kepedulian seseorang akan keberdaan suatu sumber daya berupa nilai yang diberikan oleh masyarakat kepada kawasan hutan atas manfaat spiritual, estetika dankultural.

2. Nilai warisan adalah nilai yang diberikan masyarakat yang hidup saat ini terhadap sumber daya, agar tetap utuh untuk diberikan kepada generasi akan datang. 
Manfaat menghitung nilai ekonomi langsung yaitu sebagai dasar penyusunan kebijakan pengelolaan sumber daya sehingga alokasi dan alternative penggnaannya dapat ditentukan secara benar dan mengenai sasaran.

Nilai guna langsung dan tidak langsung dari :

a) Ekosistem hutan bakau yang mendukung kehidupan ekosistem wilayah pantai.

Nilai guna langsung dari ekosistem hutan bakau terdiri dari :

1. Penghasil kayu :bakar, arang, bahan bangunan.

2. Penghasil bahan baku industry.

3. Penghasil bibit ikan, nener, kerang, kepiting, bandeng melalui pola tambak silvofishery.

4. Tempat wisata, penelitian \& pendidikan.

5. Menghasilkan bahan pelapukan yang menjadi sumber makanan penting bagi plankton, sehingga penting pula bagi keberlanjutan rantai makanan.

6. Tempat memijah dan berkembangbiaknya ikan-ikan, kerang, kepiting dan udang.

7. Tempat berlindung, bersarang dan berkembangbiak dari burung dan satwa lain.

8. Sumber plasma nutfah \& sumber genetic.

9. Merupakan habitat alami bagi berbagai jenis biota.

Nilai guna tidak langsung dari ekosistem hutan bakau adalah sebagai berikut :

1. menjaga agar garis pantai tetap stabil.

2. Melindungi pantai dan sungai dari bahaya erosi dan abrasi.

3. Menahan badai / angin kencang dari laut.

4. Menahan hasil proses penimbuna nlumpur, sehingga memungkinkan terbentuknya lahan baru. 
5. Menjadi wilayah penyangga, serta berfungsi menyaring air laut menjadi air daratan yang tawar.

6. Mengelola limbah beracun, penghasil $\mathrm{O} 2$ dan penyerap $\mathrm{CO} 2$.

b) Taman nasional bukit barisan selatan ( TNBBS )

Nilai guna langsung yang dapat diperoleh dari Taman Nasional Bukit Barisan Selatan adalah sebagai berikut :

1. Digunakan untuk kepentingan pendidikan, penelitian, penunjang budidaya, rekreasi dan wisata alam.

2. Cadangan alternative energy pembangkit tenaga listrik tenaga panas bumi (PLTP).

3. Habitat bagi tumbuhan dan hewan baik yang dilindungi maupun tidak dilindungi.

Nilai guna tidak langsung yang dapat diperoleh adalah sebagai berikut :

1. Mampu menyerap dan menyimpan cadangan karbon.

2. Memiliki fungsi hidrologis.

3. Sebagai kawasan pemeliharaan keanekaragaman jenis satwa dan tumbuhan beserta ekosistemnya.

4. Mencegah kekeringan di daerah sekitarnya.

5. Air untuk mengairi sawah, ladang, mikrohidro, perikanan dan lain sebagainya.

c) Perkebunan Aren atau Anau.

Nilai kegunaan langsung yang dapat diperoleh dari perkebunan kelapa sawit adalah:

1. Sebagai bahan baku industry peghasil pangandan non pangan misalnya minyak sayur, sabun, dan lain-lain.

2. Mampu membuka lapangan pekerjaan bagi masyarakat sekitarnya.

3. Meningkatkan kesejahteraan masyarakat.

4. Menghasilkan biomassa. 
5. Limbahnya dapat digunakan untuk membuat pupuk.

Nilai guna tidak langsung dari perkebunan kelapa sawit salah satunya adalah dapat merangsang tumbuhnya industry pengolahan yang bahan bakunya dari Aren.

\section{E. Pembangunan Ekonomi dan Lingkungan}

Ada waktu, beberapa dekade yang lalu, ketika masalah kualitas lingkungan secara luas dianggap sebagai yang unik untuk dikembangkan ekonomi industri. Pengembangan industri dikaitkan dengan polusi udara dan air, overreliance pada bahan kimia, hawar visual dan sebagainya. Negara-negara berkembang, bagaimanapun, dianggap memiliki masalah lingkungan lebih sedikit karena teknologi praindustri mereka lebih ramah lingkungan dan karena mereka belum berkomitmen untuk gaya materialistis hidup.

Ide-ide ini telah berubah, namun untuk satu hal itu telah menjadi jelas bahwa kerusakan lingkungan besar-besaran telah terjadi di negara berkembang. daerah pedesaan telah melihat erosi skala besar tanah dan kualitas air kerusakan, deforestation dan produktivitas tanah menurun. Daerah perkotaan mengalami berkurang serius kualitas udara dan air. Selanjutnya, perburukan lingkungan di negara-negara berkembang tidak hanya soal estetika atau kualitas hidup, melainkan masalah yang lebih serius yang melibatkan diminishment produktivitas ekonomi dan percepatan dislokasi sosial. Selain itu, negara-negara berkembang jelas ingin menempatkan prioritas yang kuat pada pertumbuhan ekonomi; dengan demikian, interaksi antara pertumbuhan dan kualitas lingkungan adalah sangat penting.

Mengeksplorasi keterkaitan pembangunan ekonomi dan lingkungan antara negaranegara nonindustrialized dunia. Sesuai dengan perbedaan yang dibuat dalam pendekatan pada dua tingkat positif dan normatif. Dari sudut pandang positif, masalahnya adalah untuk memahami bagaimana pembangunan dan degradasi 
lingkungan yang timbal balik terkait dan faktor-faktor apa yang menjelaskan keterkaitan ini. Dari sudut pandang normatif, masalahnya adalah untuk berurusan dengan pertanyaan tentang jenis penetapan kebijakan publik yang paling sesuai untuk negara-negara berkembang seperti Indonesia. 


\section{DAFTAR PUSTAKA}

Azhar Zul. 2012. Teknik Perencanaan Pembangunan (Berbasis Aplikasi Komputer). Padang: FE UNP.

Azhar Zul. 2010.Perencanaan Pembangunan (Konsep, Teori, Model, teknik, Aplikasi).Padang: FE UNP.

Azhar Zul. 2006. Ekonomi Regional (Buku Ajar).Padang: FE UNP.

Lampiran Permen No. 54 Tahun 2010 Sistem Perencanaan Pembangunan

Nasional

Permen No. 54 Tahun 2010 Sistem Perencanaan Pembangunan Nasional

Ruscoe,G.C. 1982. Kondisi Untuk Keberhasilan Perencanaan Pendidikan. Jakarta: Bhratara Karya Aksara.

Sa'ud, U.S. dan Makmun, A.S. 2005. Perencanaan Pendidikan, Suatu

Pendekatan Komprehensif. Bandung: Remaja Rosdakarya.

Sjafrizal. 2014. Perencanaan Pembangunan Derah Dalam Era Otonomi.

Rajawali Press.

Usman, H. 2006. Manajemen. Teori, Praktek, dan Riset Pendidikan. Jakarta:

Bumi Aksara.

http://www.datastatistikindonesia.com/content/view/460/460/

http://blog.anashir.com/2012/10/negara-dengan-penduduk-

terbanyak.htm|\#ixzz3IjragMLu

http://blog.anashir.com/2012/10/negara-dengan-penduduk-

terbanyak.html\#ixzz3Ijsidbwh

http://www.antaranews.com/berita/380092/penduduk-dunia-capai-72-miliar-

jiwa-pada-juli-nanti.

http://internasional.kompas.com/read/2014/09/19/04550361/Di.Tahun.2100.

Jumlah.Penduduk.Dunia.Mencapai.11.Miliar

Undang-Undang Nomor 25 tahun 2004 tentang Sistem Perencanaan

Pembangunan Nasional

http://ejournal.forda-mof.org/latihan/index.php/JPSE/article/view/410 (di akses pada tanggal 24 Februari 2018 pukul 20.13 WIB)

http://www.academia.edu/1650895/KONSEP_NILAI_EKONOMI_TOTAL_DAN_

METODE_PENILAIAN_SUMBERDAYA_HUTAN (diakses pada tanggal pukul 20.45 WIB)

http://penilai23.blogspot.co.id/2016/12/konsep-nilai-ekonomi-total.html (diakses pada tanggal 25 februari 2018 pukul 10.14 WIB)

http://jurliablog.blogspot.co.id/2016/05/konsep-nilai-ekonomi-total-nilai-guna.html (diakses pada tanggal 25 februari 2018 pukul 11.06 WIB)

http://studyandlearningnow.blogspot.co.id/2013/06/pengertian-dan-kreteriakawasan-sentra.html 


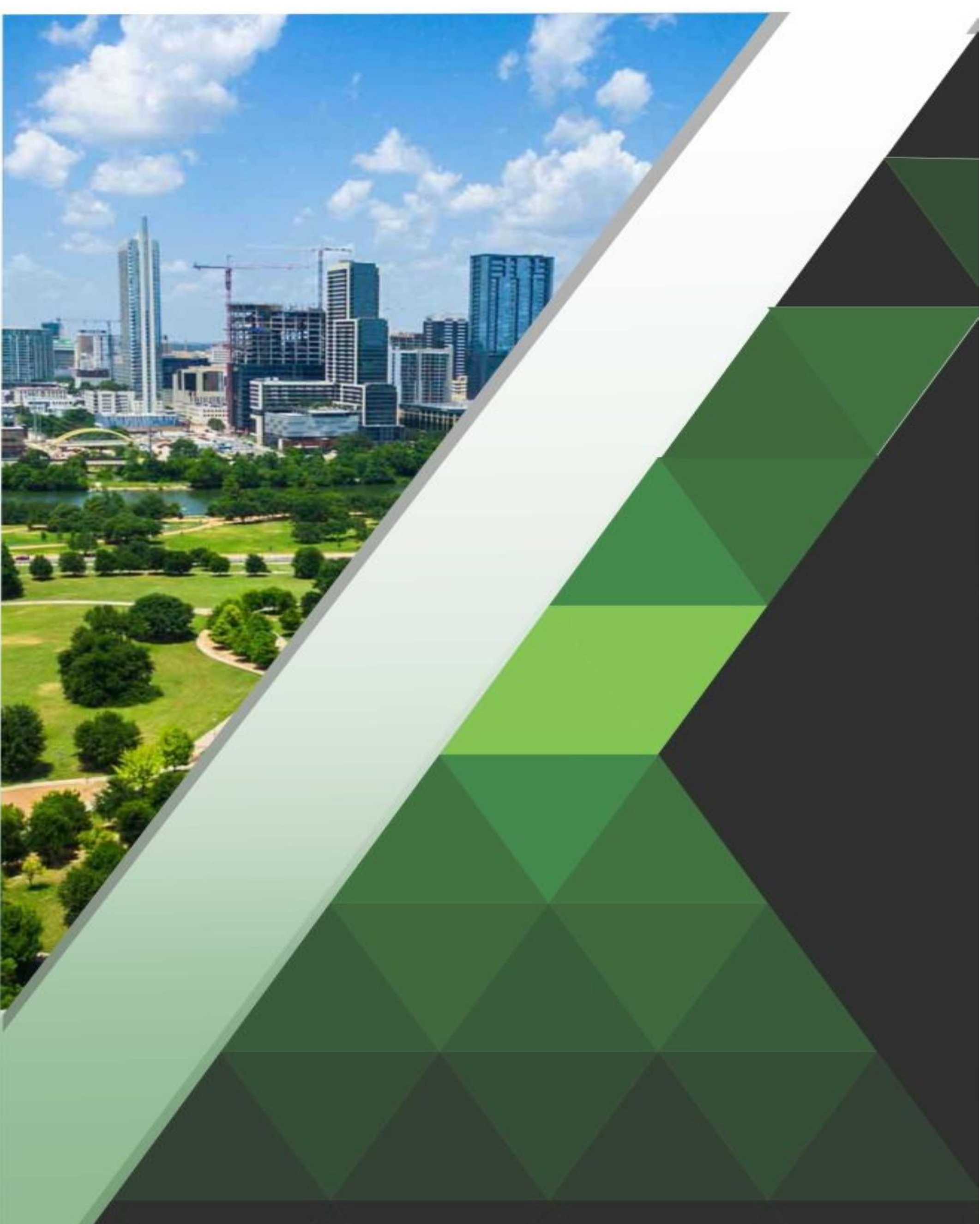

